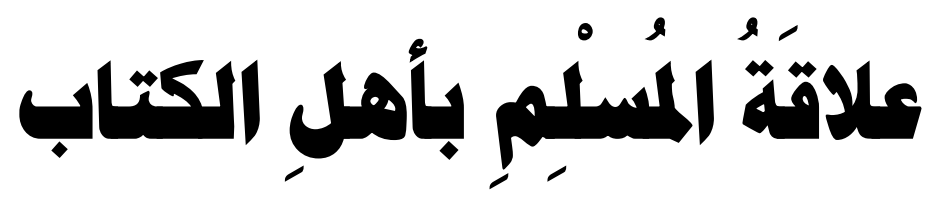 في ميزان القرآن
}

إعداد الباهث الدكتور

منصور محمود مسن أبو زينة

الأستاذ المشارك في قسم أصول الدين

تنصص التفسير و علوم القرآن

كلية الشريعة / جامعة اليرموك

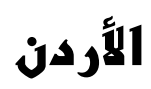


- $\varepsilon \mu$. 


\section{مَلَََّمَ البحْث}

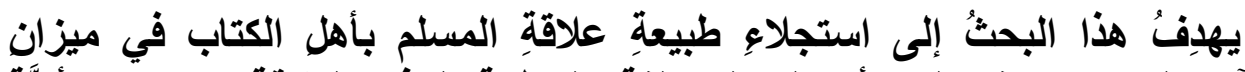

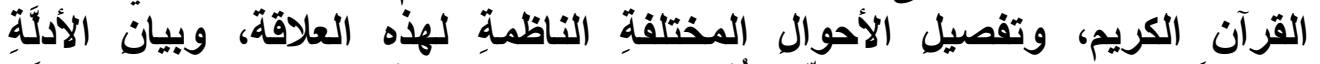

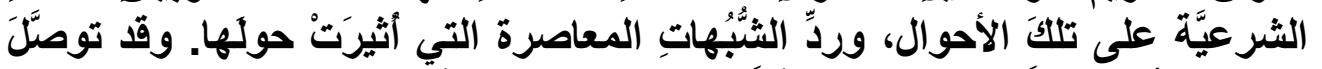

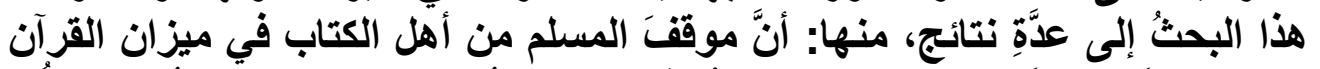

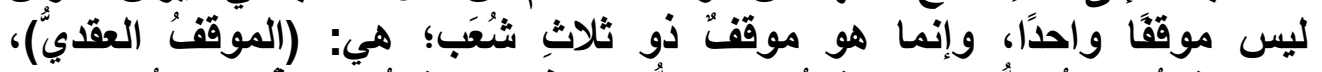

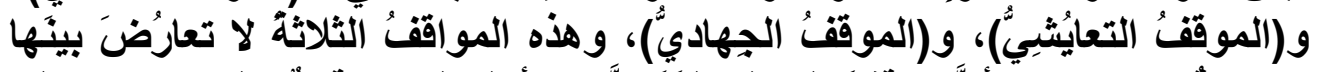

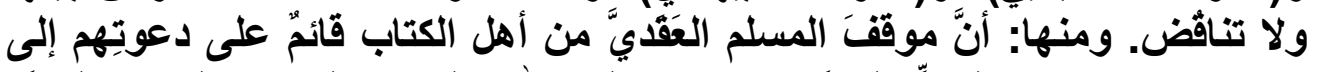

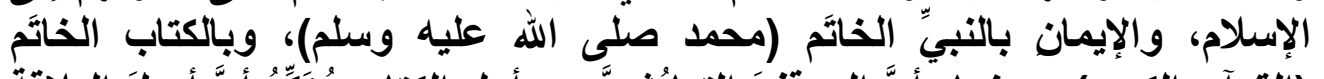

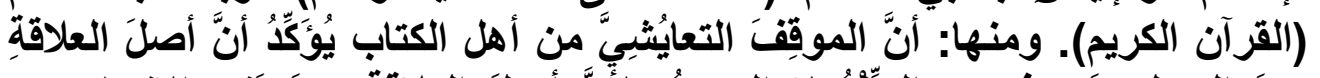

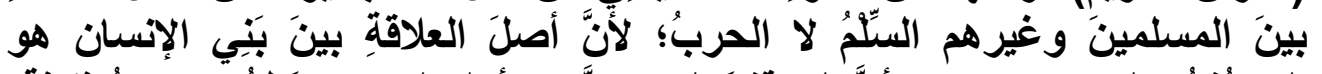

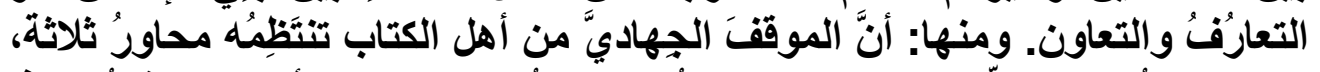

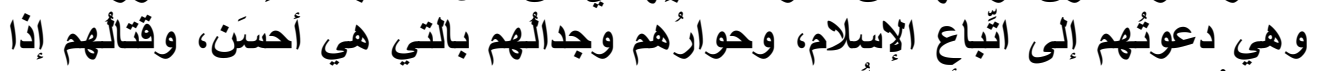

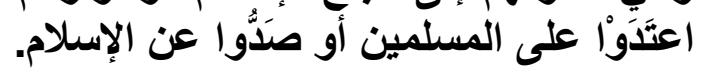
الكلمات الدالة: موقف، القرآن، أهل الكتناب. 


\section{Abstract}

The aim of the study was to identify the nature of the relationship between Muslims, Christians and Jews in the Holy Quran, to detail the different situations organizing this relationship, provide some Shari evidences about these situations, and to refute the accusations and arguments surrounding the nature of the relationship between Muslims, Christians and Jews. The study concluded with several results, including that the position of Muslims towards Christians and Jews in the Holy Quran is not the same, but takes three main forms: The Aqeeda situation, The coexistence situation and The Jihadi situation. These three situations do not include any paradox or contradiction. This is evident when knowing that the Aqeeda position clarified in the Holy Quran for Muslims towards Christians and Jews is very clear, and does not include any obscurity as the Holy Quran has declared that Christians and Jews are basically non- believers, that they did not believe in the Prophet Mohammad, the final prophet on Earth, nor did they believe in the Holy Quran, the last Holy Book sent to man and thus, their religion will not be accepted by them. The second position is coexistence, which includes the fact that the essence of the relationship between Muslims, Christians and Jews is peaceful in nature, not war as humans are to interact, to know each other and to collaborate. The Jihadi position of the Holy Quran is organized by three basic principles, the first is to call Christians and Jews to embrace Islam; the second is to discuss and argue them peacefully, while the third is to fight them if they attack Muslims or they did not embrace Islam. 


\section{بسم الله الرهمز الرحيم

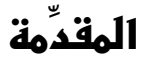

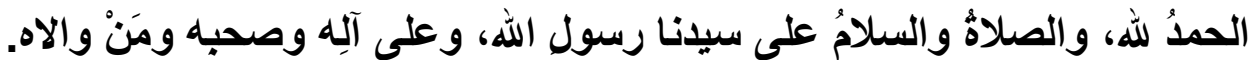

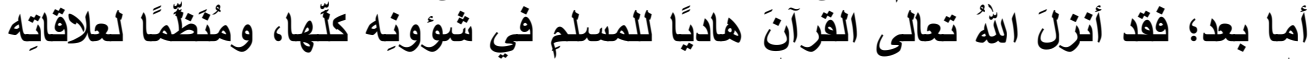

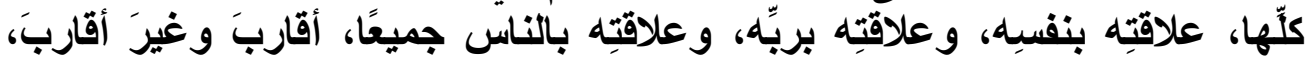

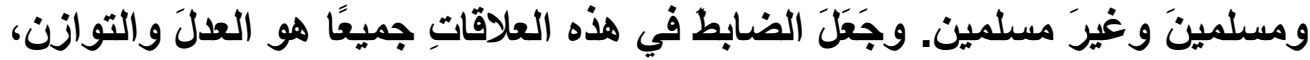

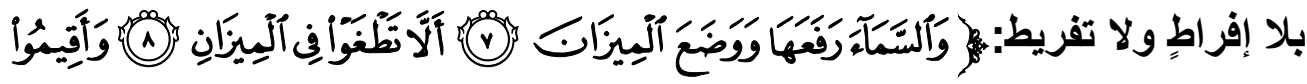

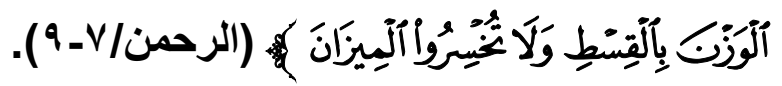

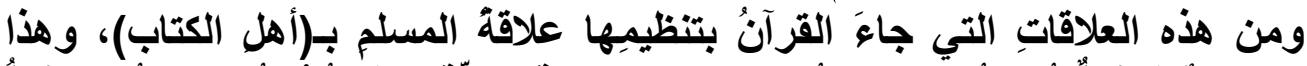

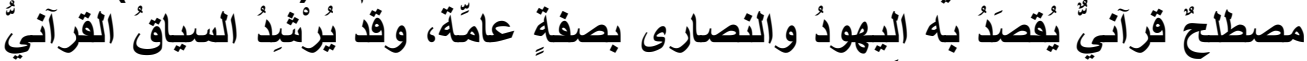

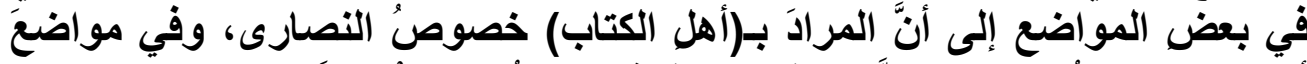

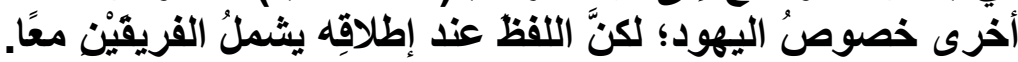

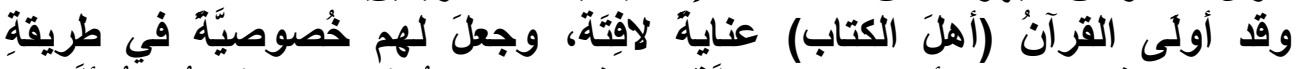

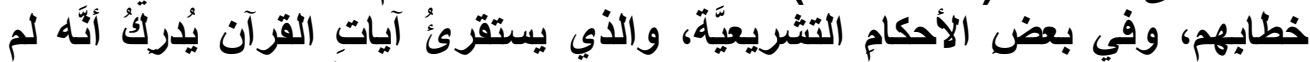

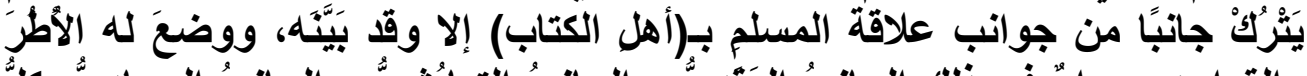

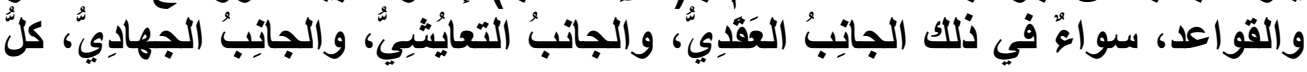

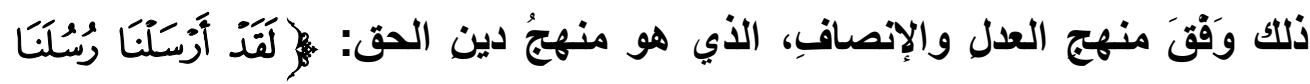

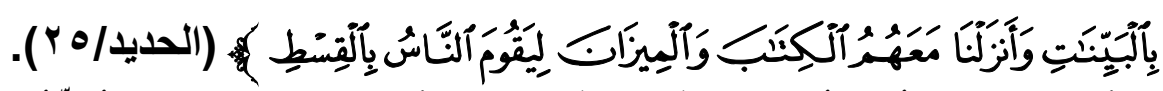

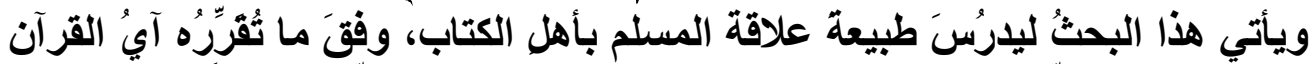

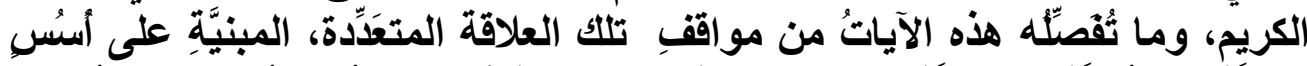

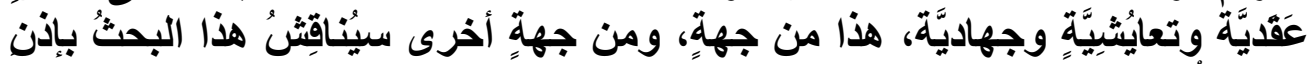

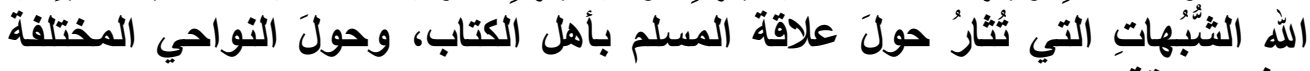

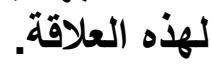

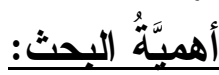

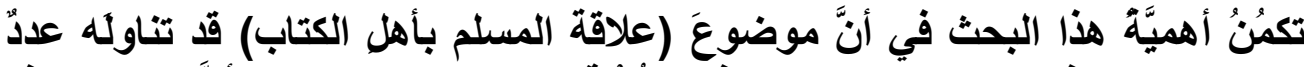

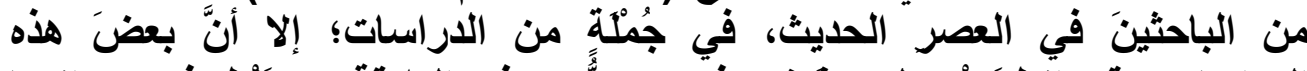

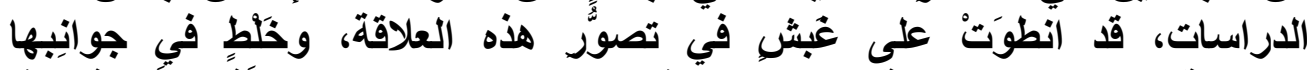

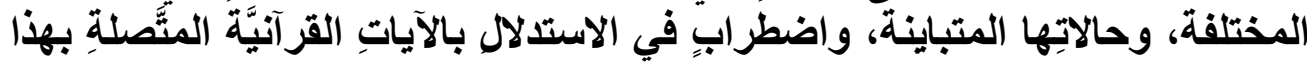

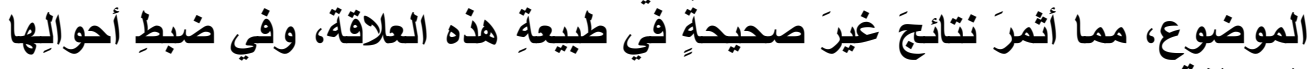

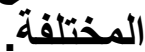

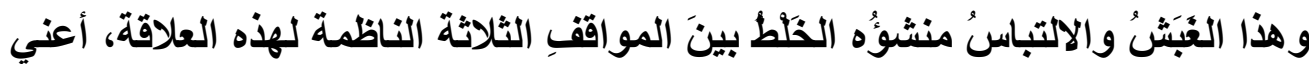

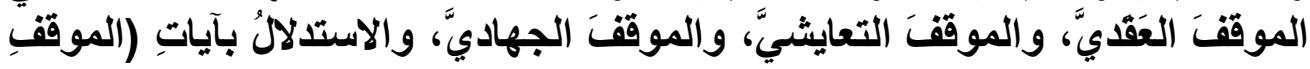




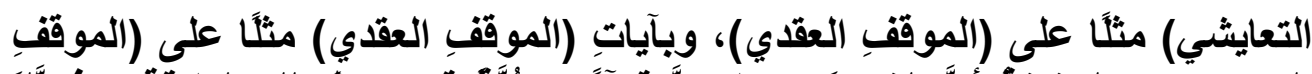

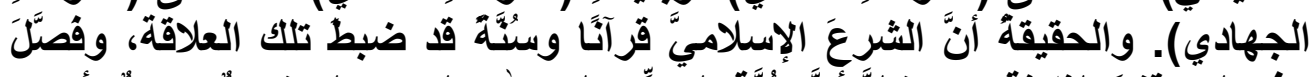

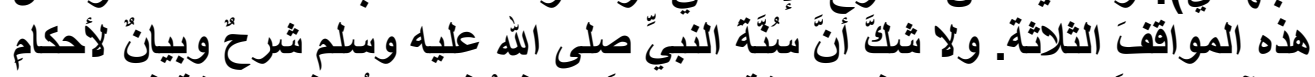

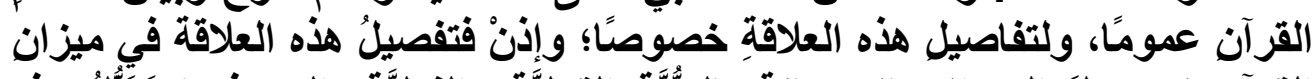

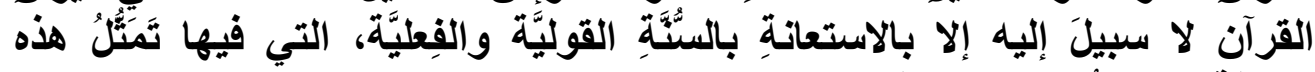

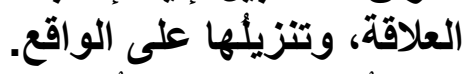

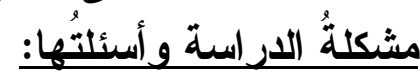

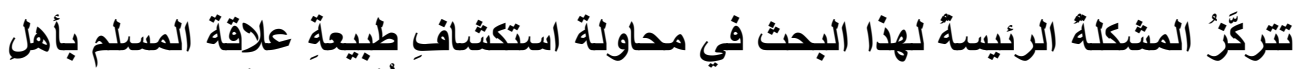

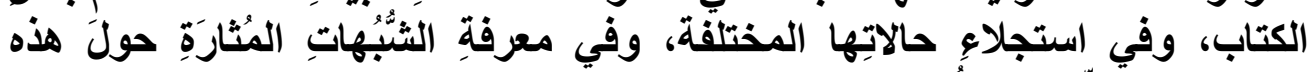

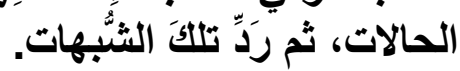

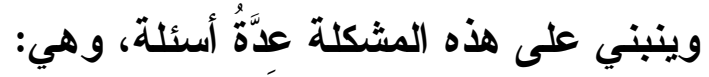

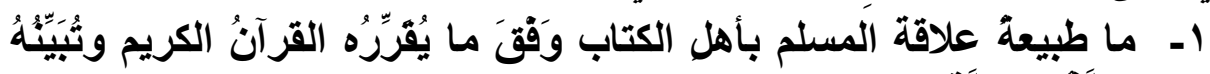

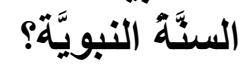

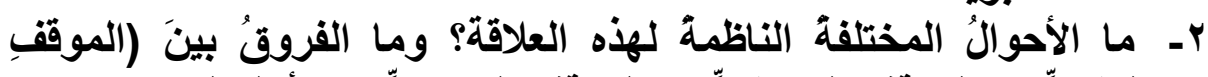

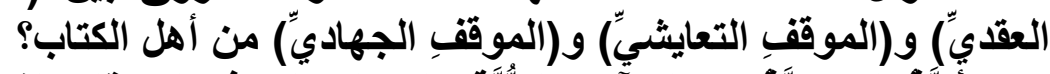

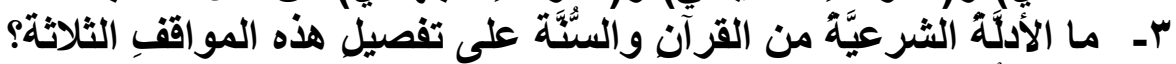

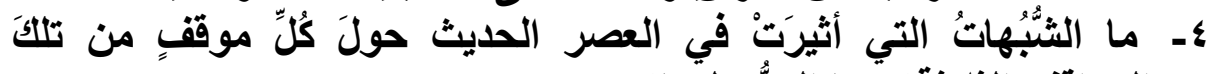

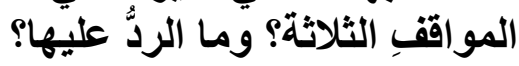

أهدافُ الادراسة:

تهدفِ هذه الدراسة إلى تحقيق الأهداف الآتية:

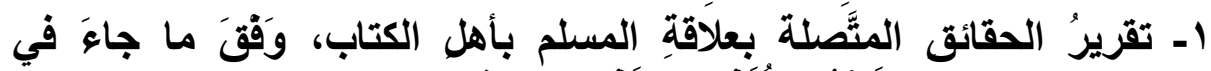

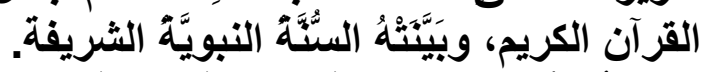

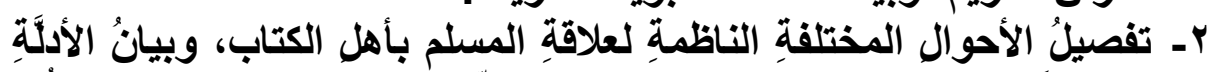

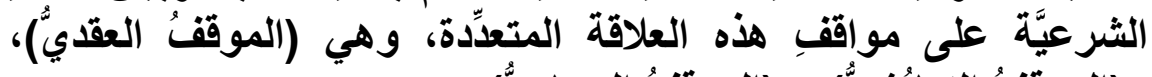

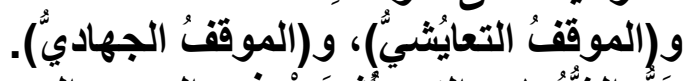

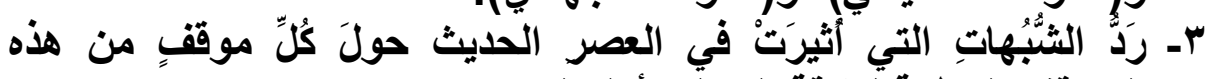

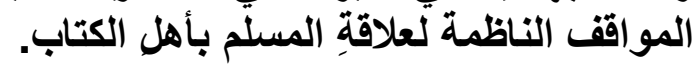

الإراساتُ السابقة:

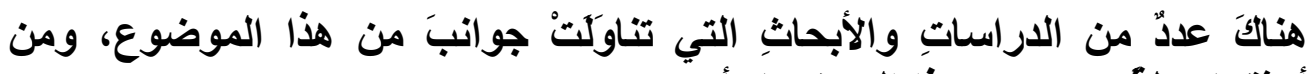

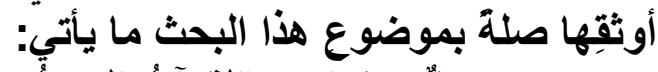

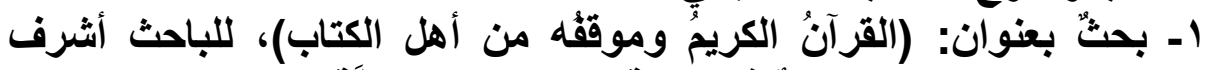

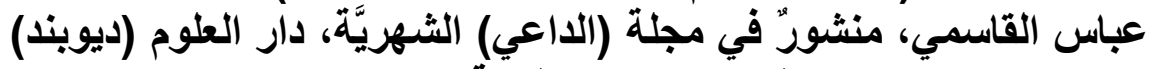

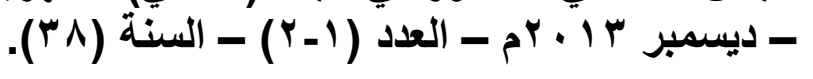




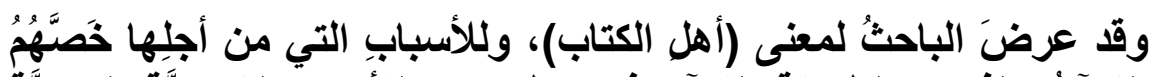

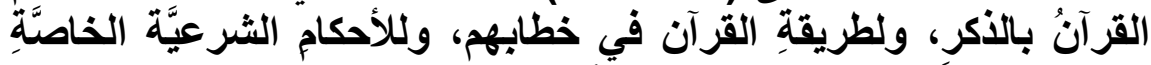

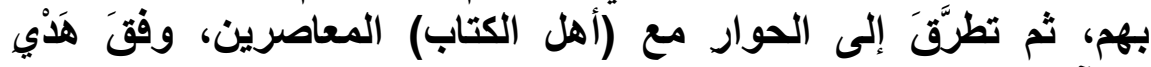

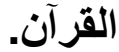

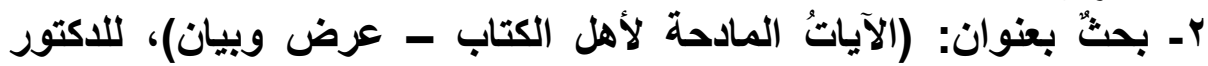

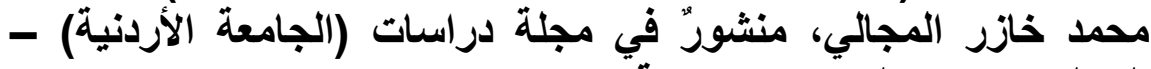

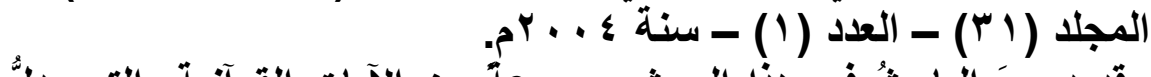

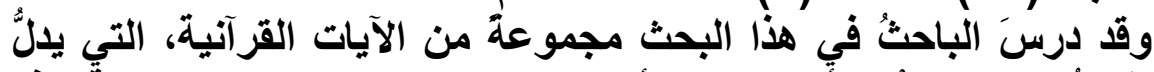

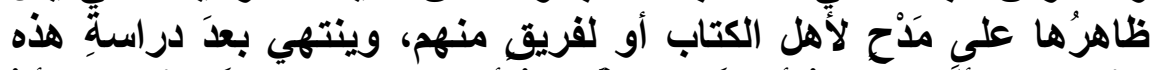

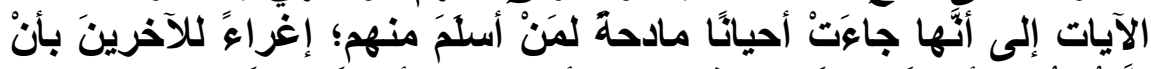

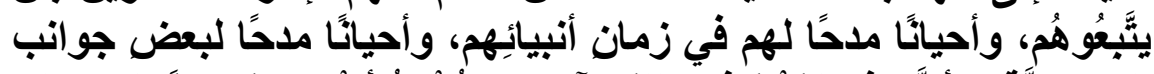

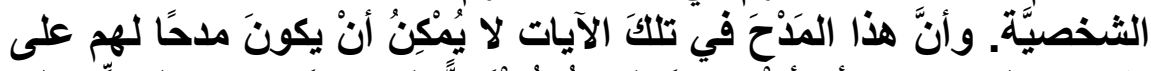

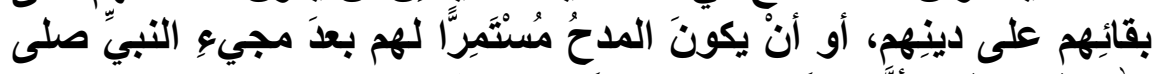

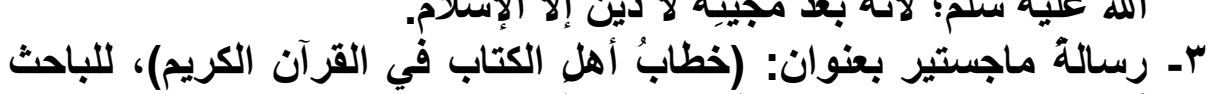

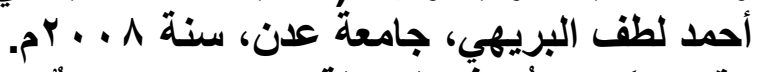

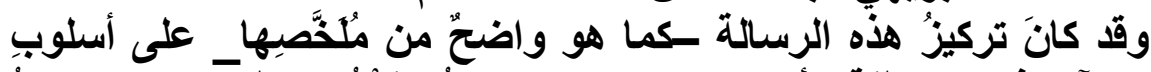

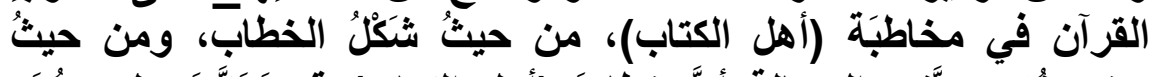

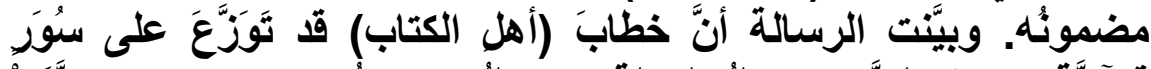

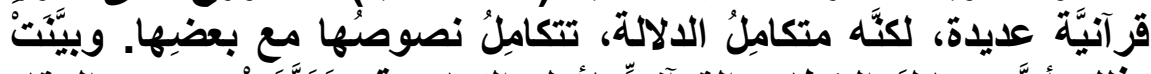

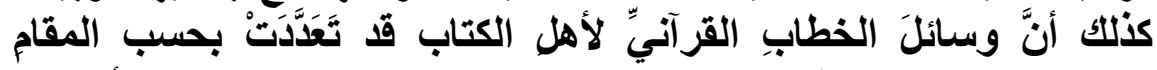

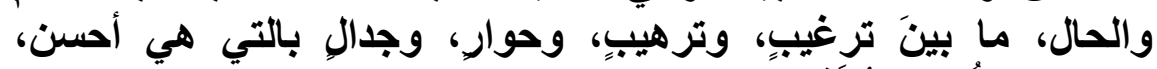

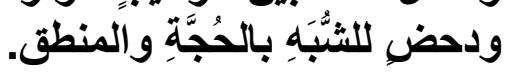
؛- كتاب (علاقة المسلمين بغير المسلمين)، للاكتور سعيد إسماعيل صيني،

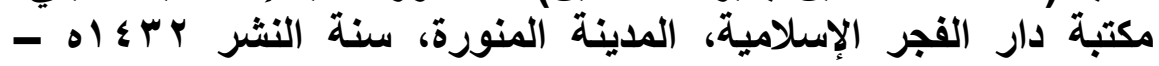

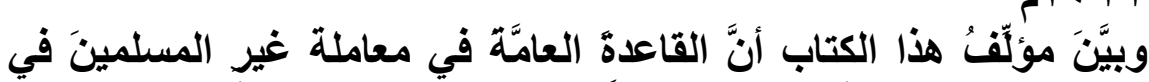

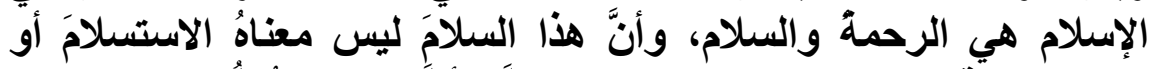

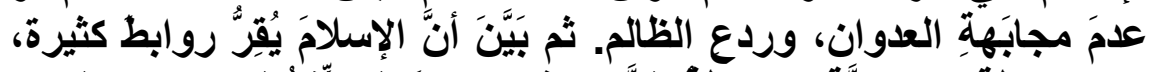

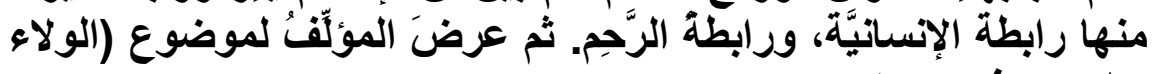

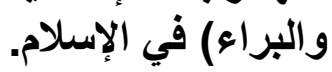


وتنفردُ در استي عن هذه الدر اسات بما يأتي:

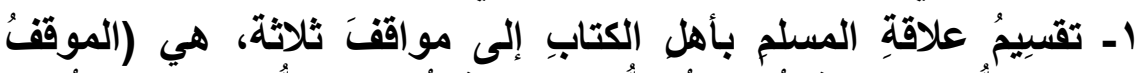

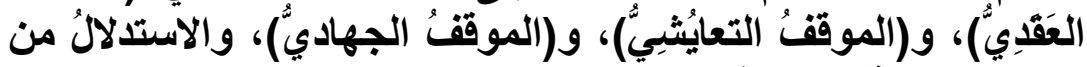

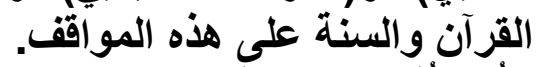

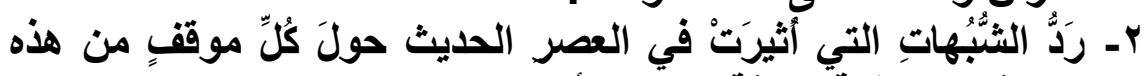
المواقف الناظمة لعلاقةِة المسلم بأهل فئل الكتاب.

منهُجُ البحث:

لتحقيق مقاصدِ هذا البحث اتََّْْتُ المناهجَ البحثيَّة الآتية:

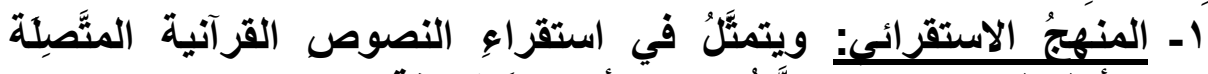

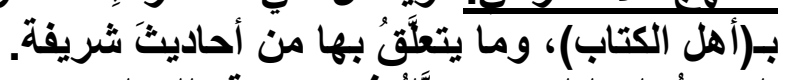

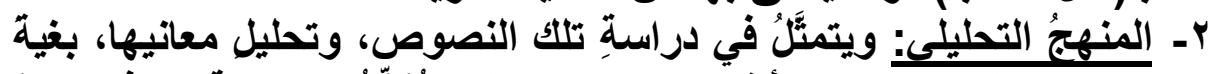

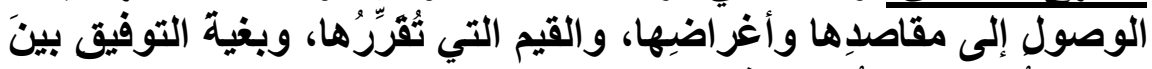

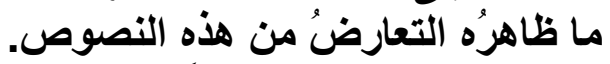

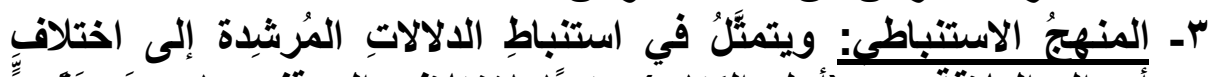

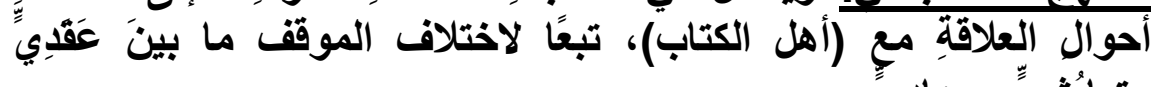
وتعايُشِيِِ وجهادِيِِ

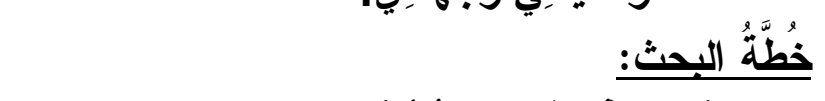

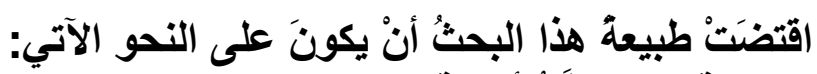

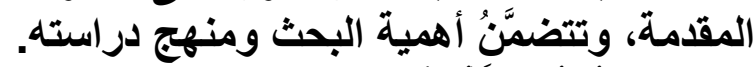

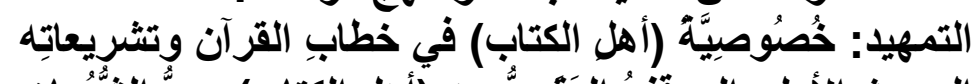

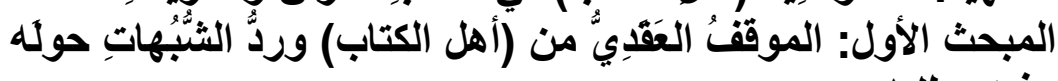

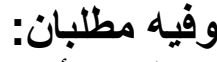

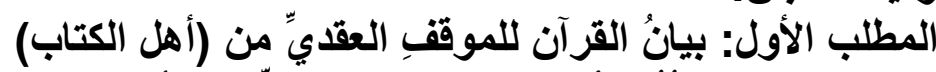

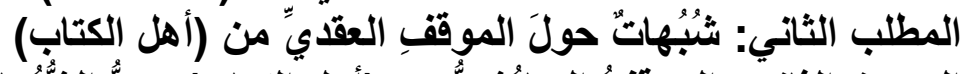

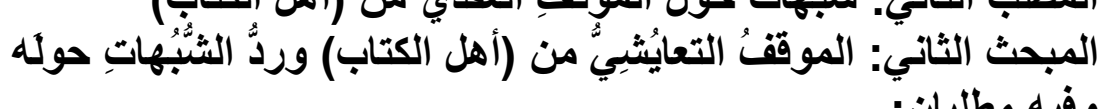

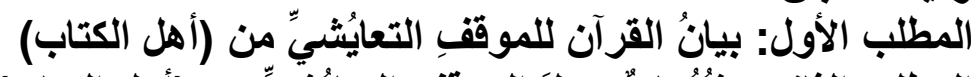

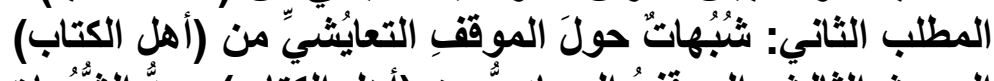

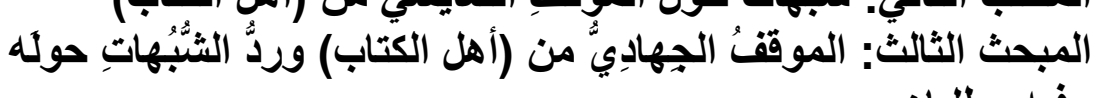
وفيه مطلبان:

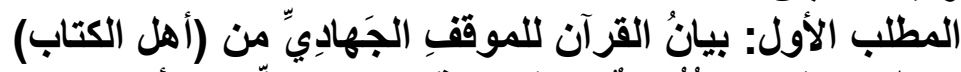

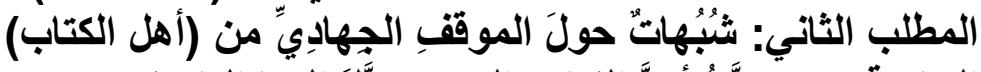

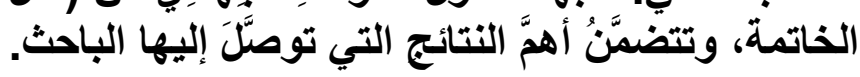




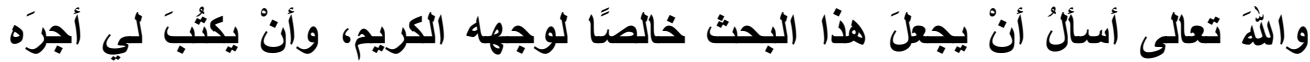

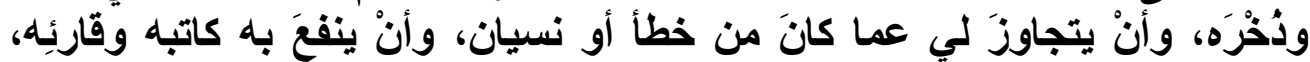

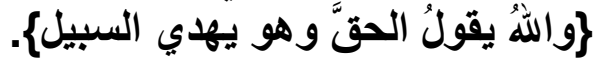

\section{التمهيد}

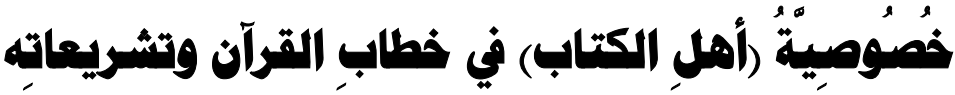

إنَّ كتابَ الله تعالى أنزلَ نورًا و هدَّى للناس، يدعُؤهُم جميعًا إلى الدخول في الإسلام،

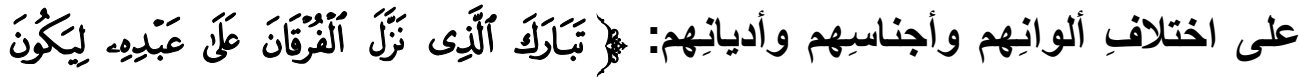

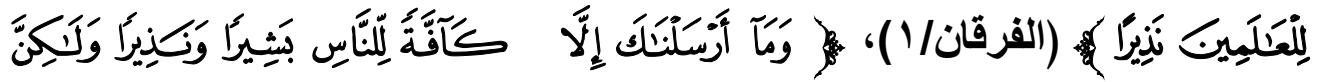

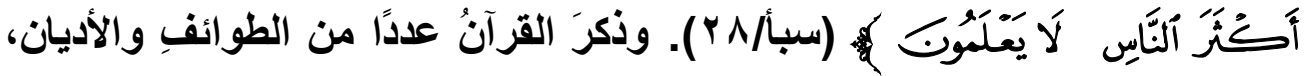

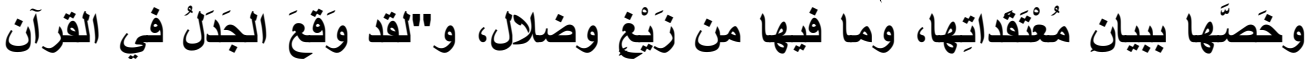

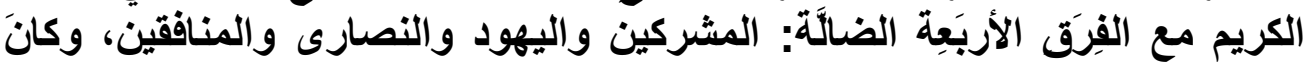

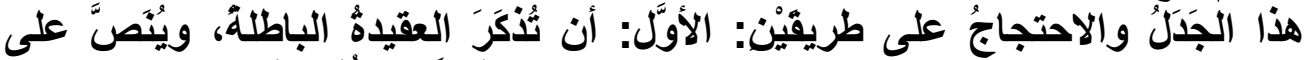

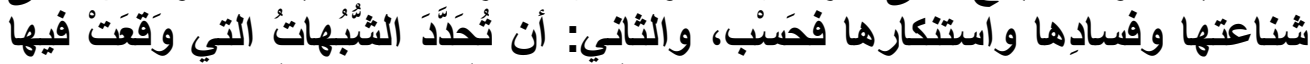

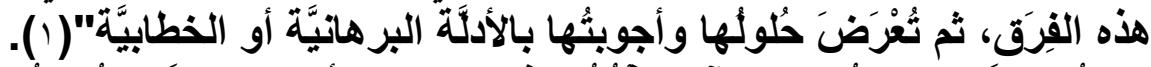

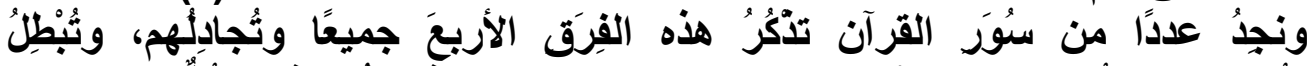

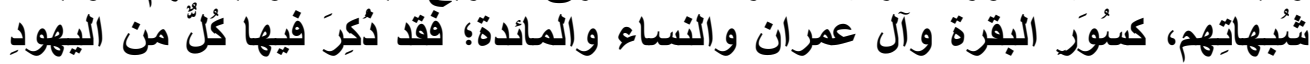

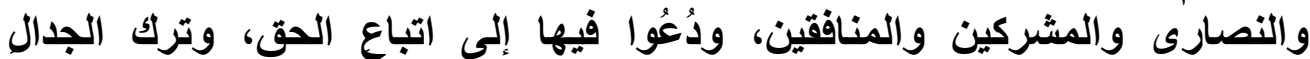

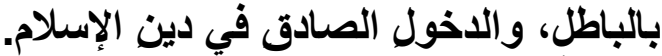

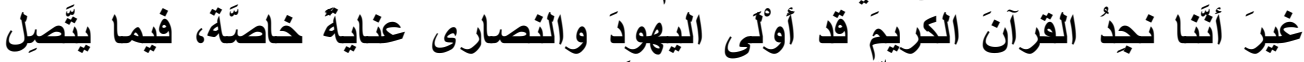

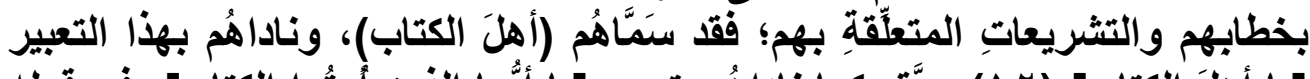

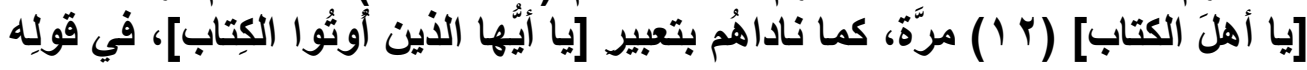

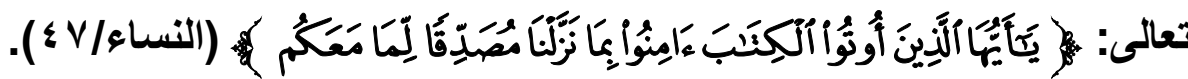

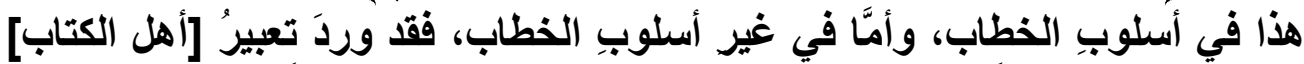

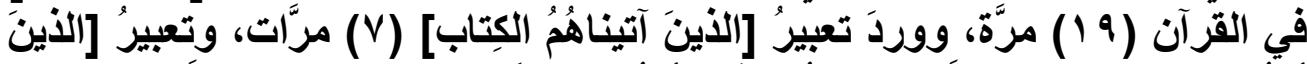

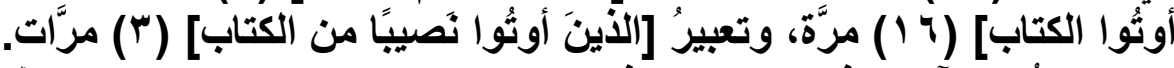

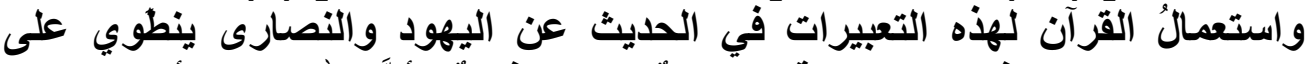

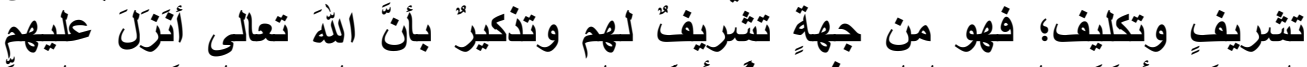

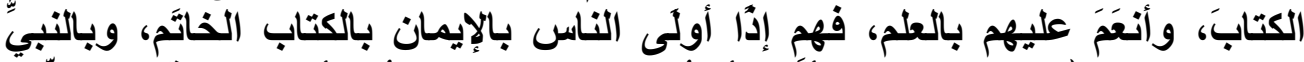

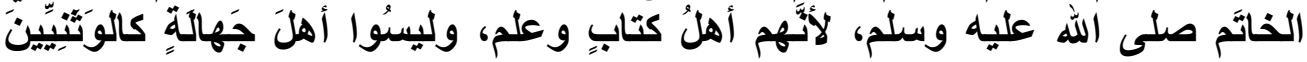

(') الدهلوي، الفوز الكبير في أصول التفسير، صبr. 
ونحوهم. وهو من جهةٍ أخرى تكليفّ لهم بأنَّ الإيمانَ منهم أوجَب، وأنَّ وزرَهُم

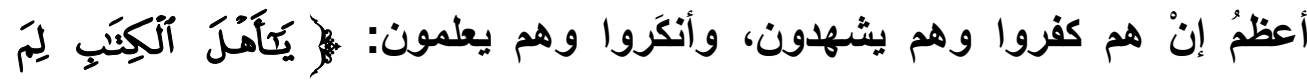

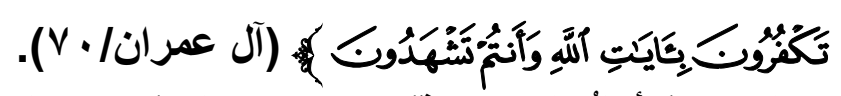

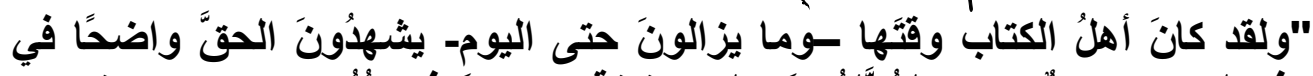

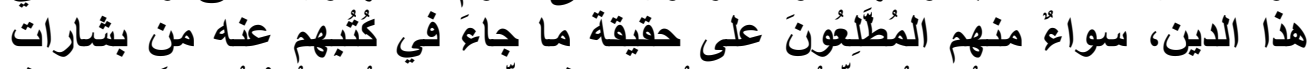

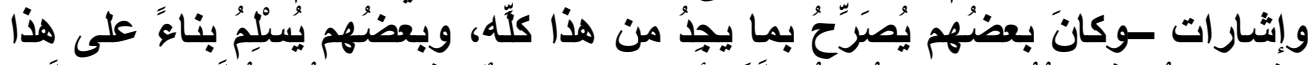

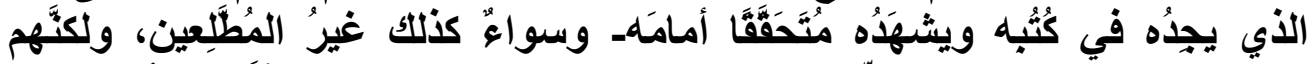

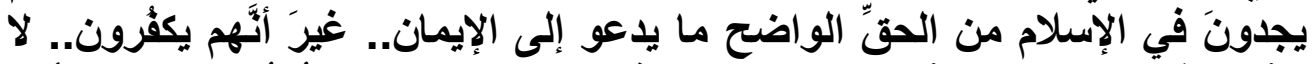

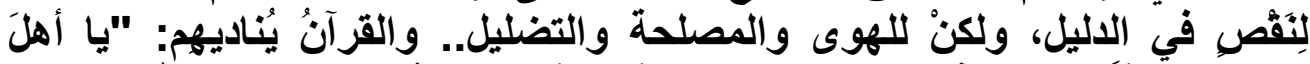

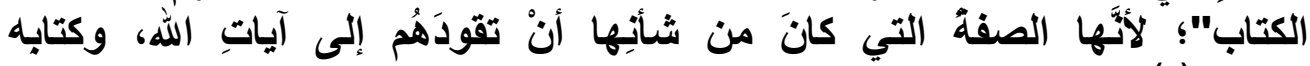

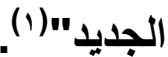

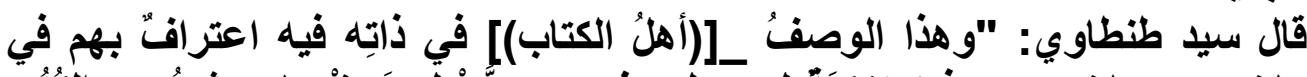

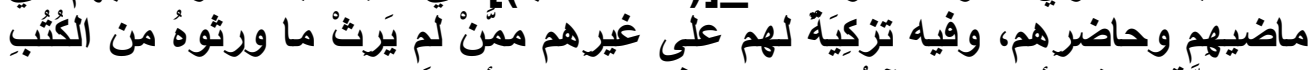

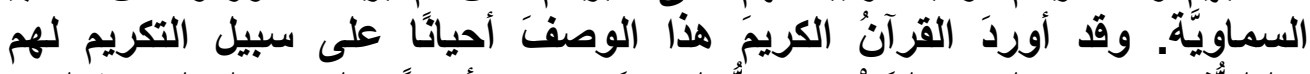

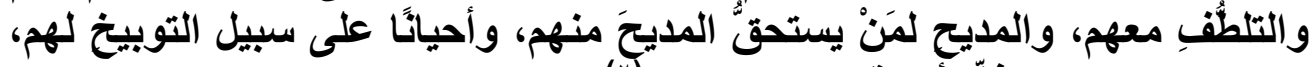

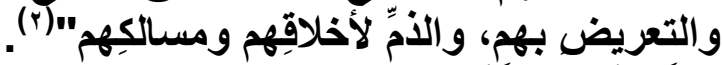

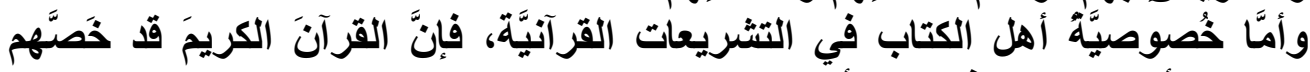
بعض الأحكام، ومن ذلك ما يأتي: التئي

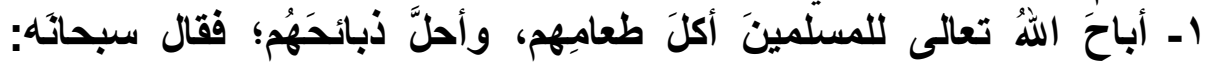

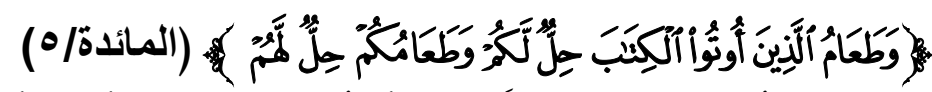

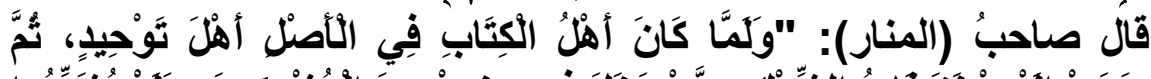

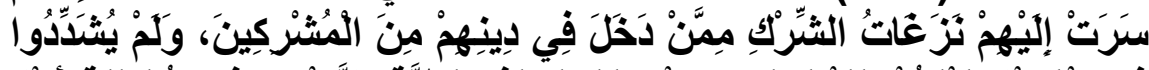

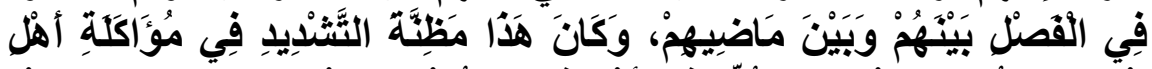

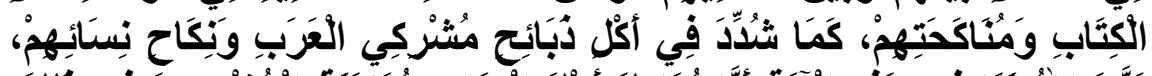

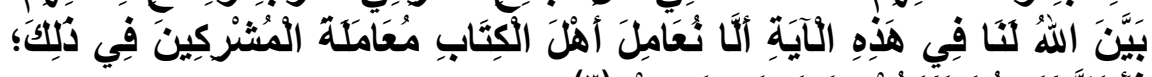

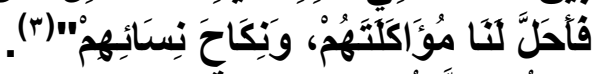

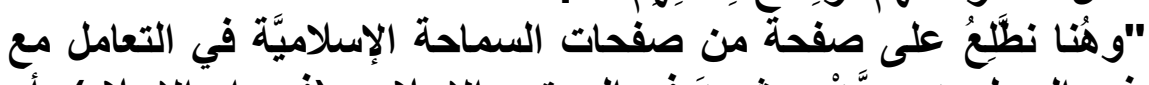

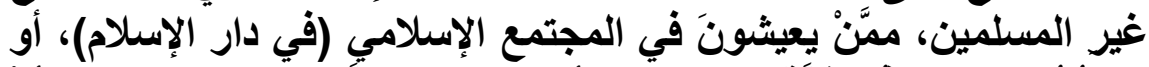

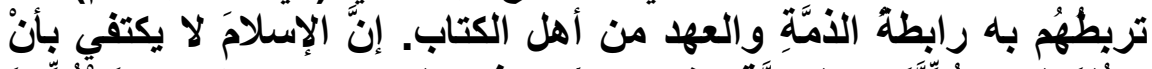

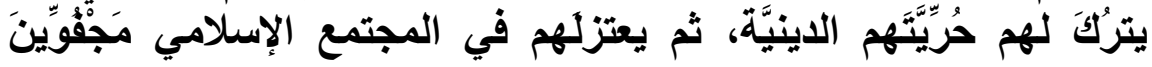

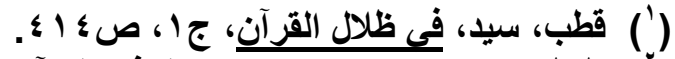

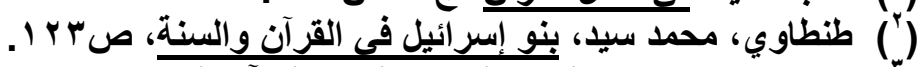

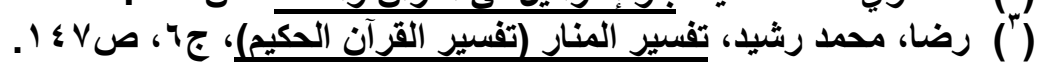


معزولينَ أو منبوذين، إنَّما يشملهم بجُوِ من المشاركة الاجتماعيَّة،

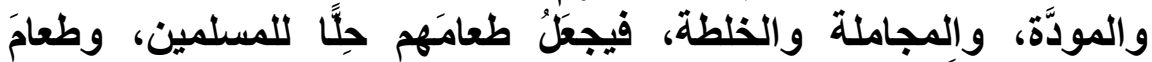

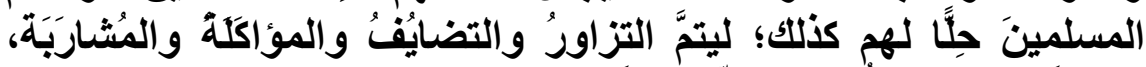

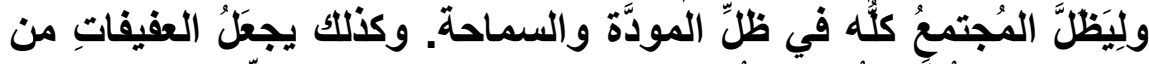

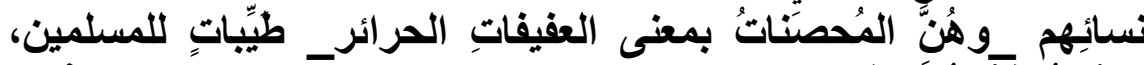

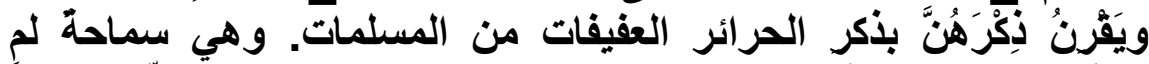

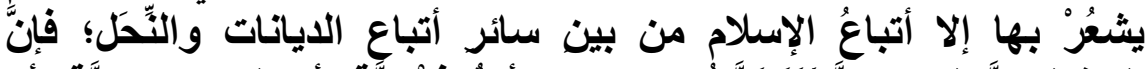

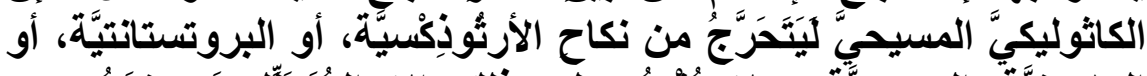

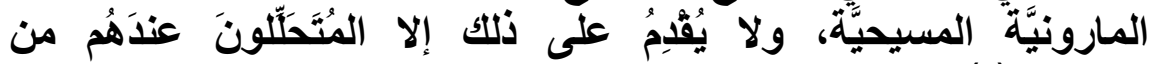

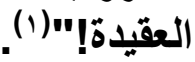
r- أباحَّ اللهُ تعالى للمسلمينَ الزواجَ بالكتابيَّة، بخلافِ المُشْركة؛ فقالَ سبحانَه

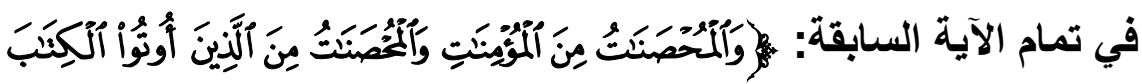

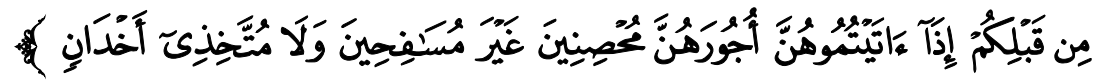
(المائدة/ه) قال الزحيلي في تعليل إباحة الزواج بالكتابيَّة: "والسبب في إباحة الزواج

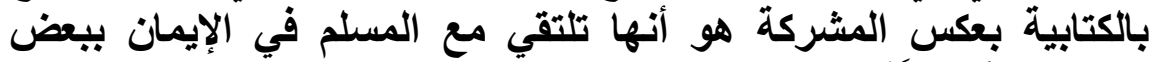

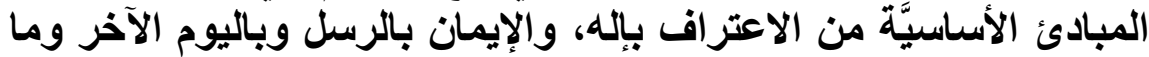

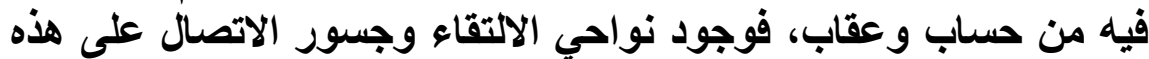

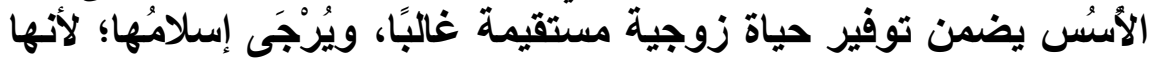

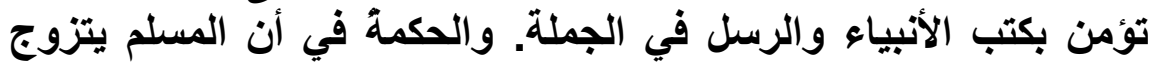

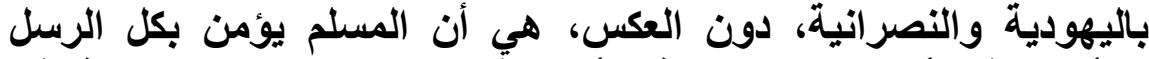

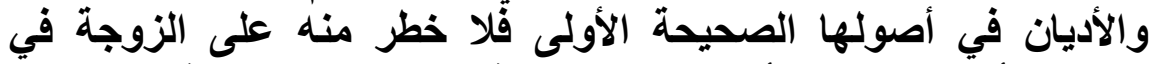

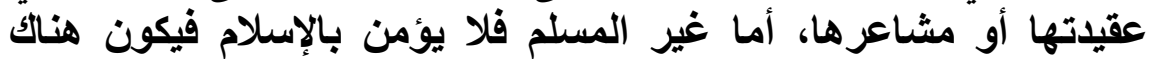

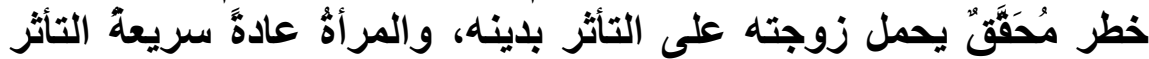

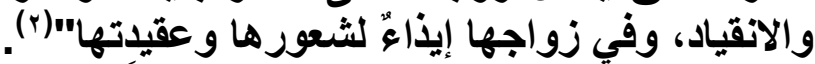

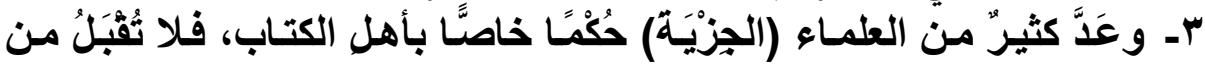

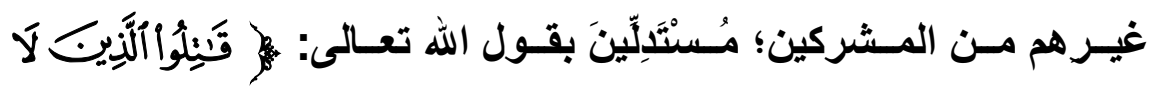

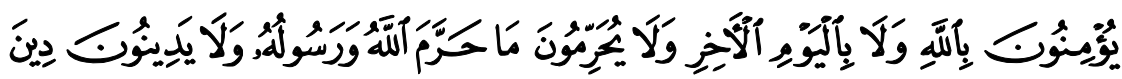

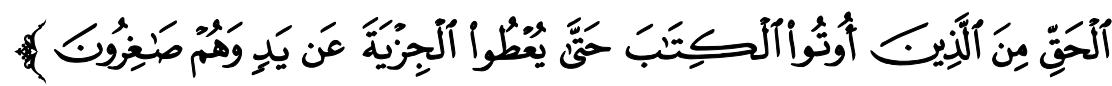

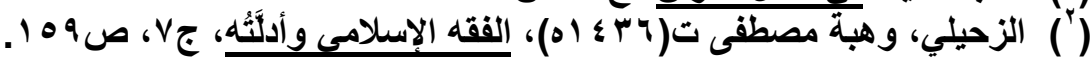


(التوبة/9 ب)، واختصاصُ أهل الكتاب بقبول الجزيـة منهم مسألة خلافيَّة،

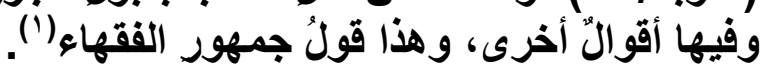

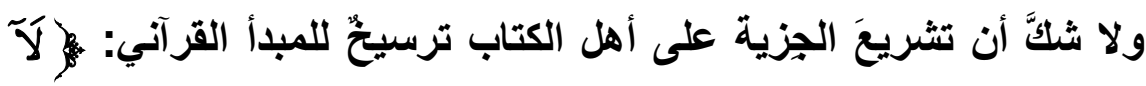

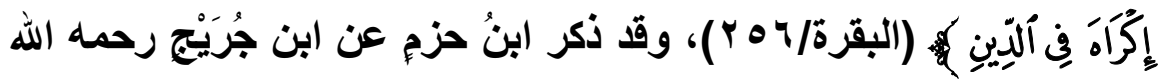

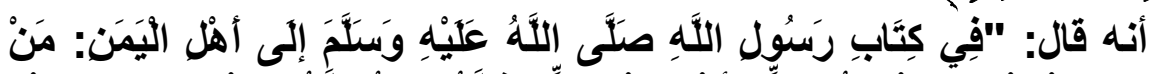

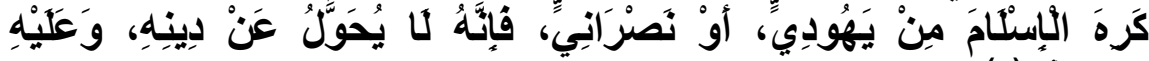

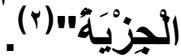

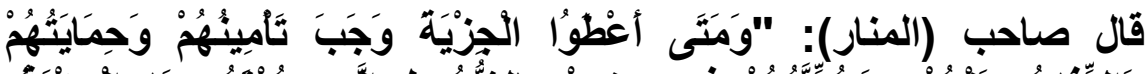

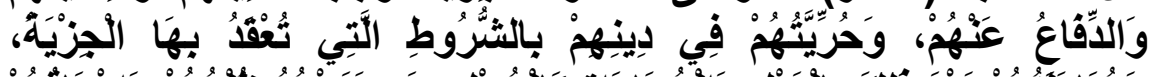

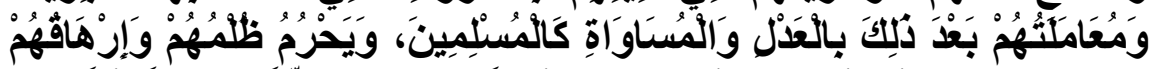

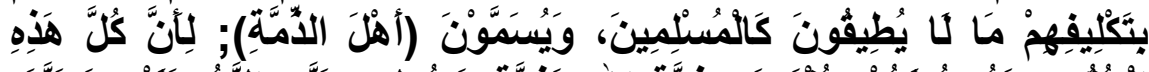

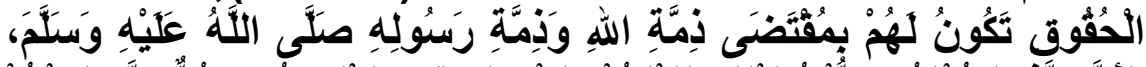

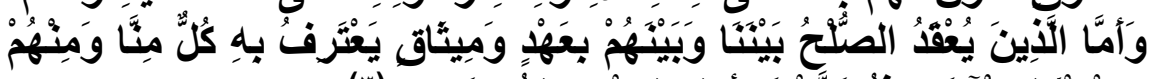

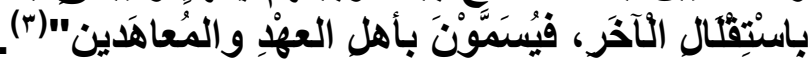

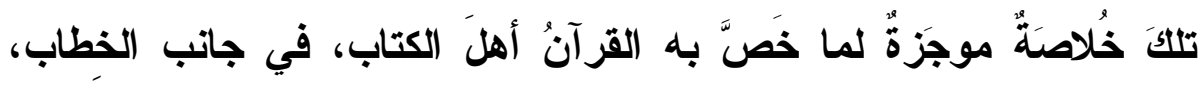

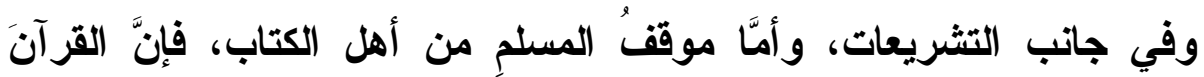

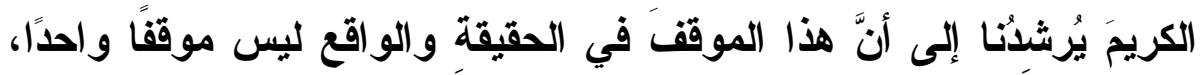

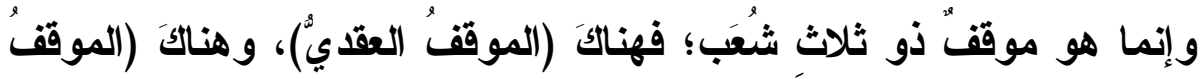

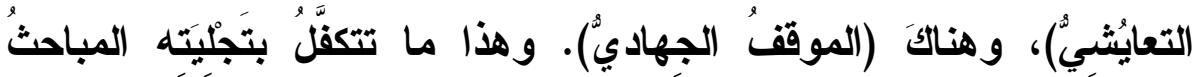

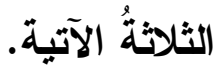

(') ينظر تفصيلُ هذه الأقوال في: الموسوعة الفقهيَّة الكويتئة، جماعة من العلماء اوزارة

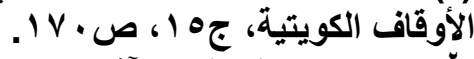

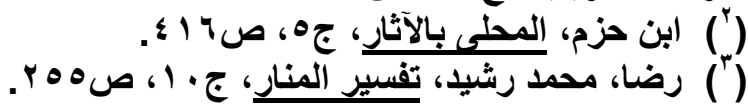




\section{المبمث الأول

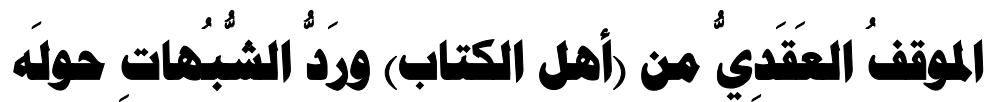 \\ المطلب الأول}

بيانُ القرآن الموقفِ العقديِِّ من (أهل الكتناب)

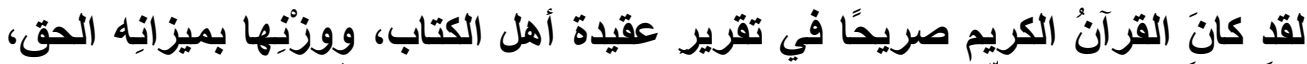

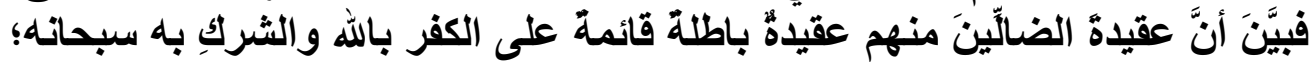

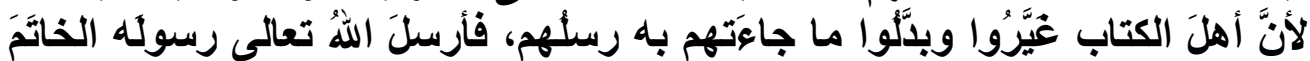

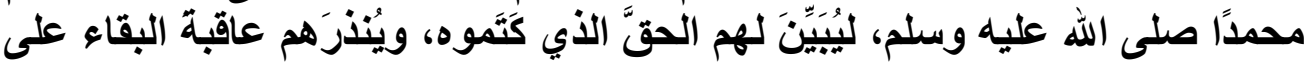

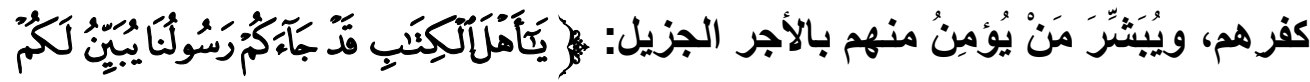

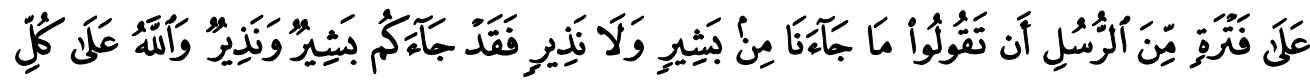

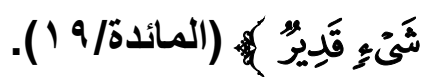

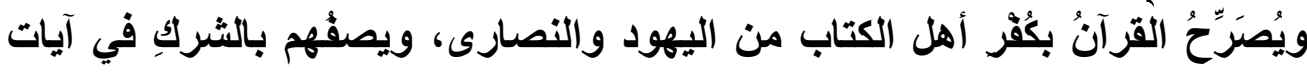

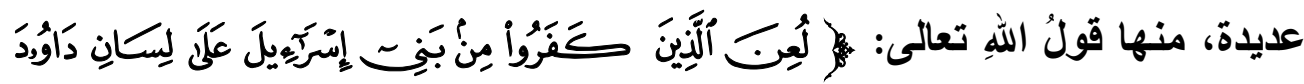

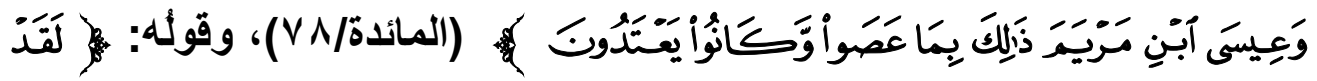

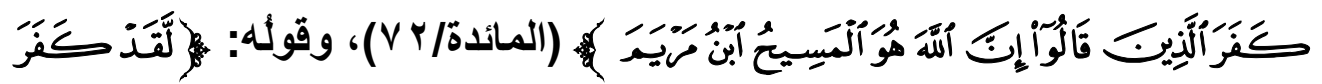

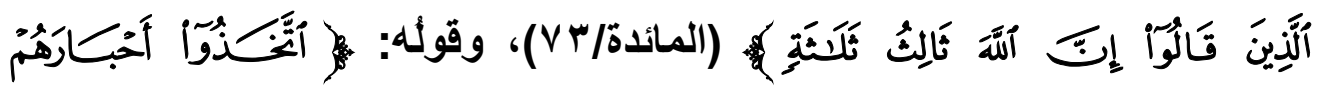

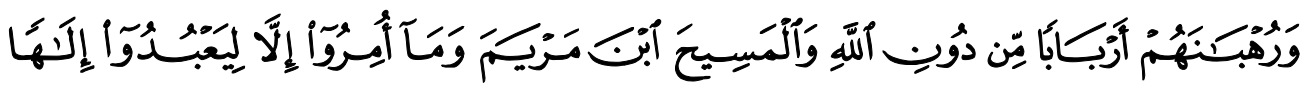

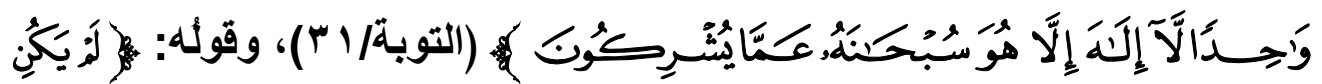

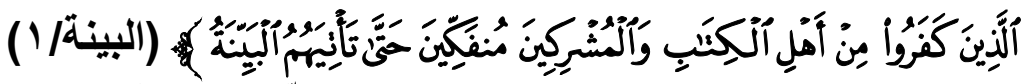

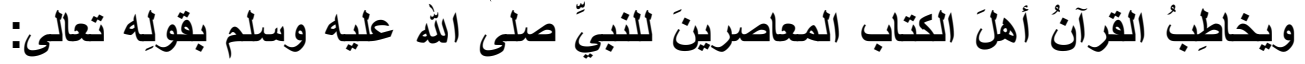

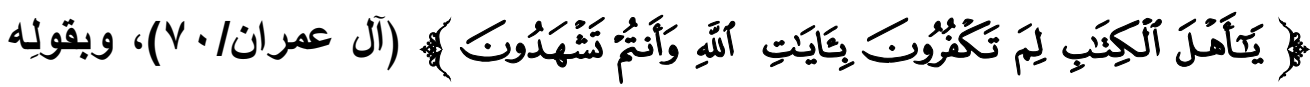

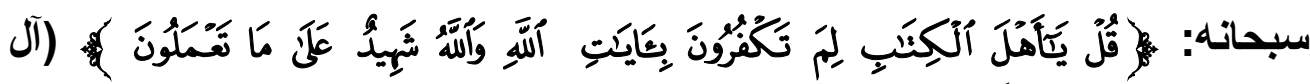

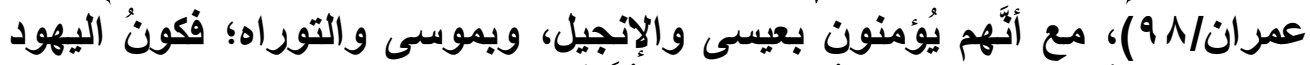

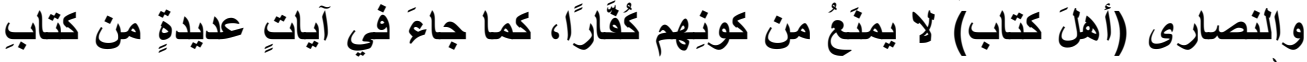

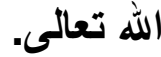




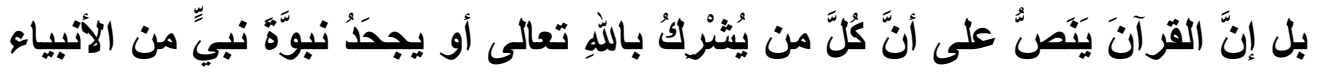

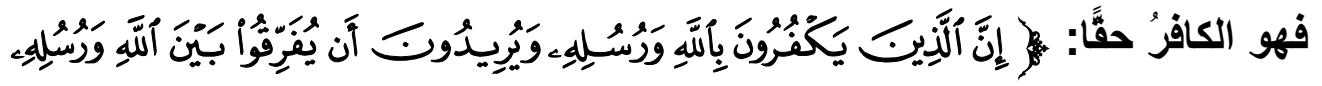

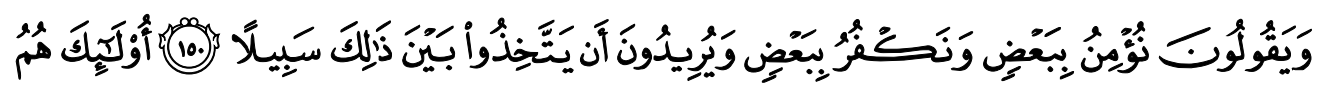

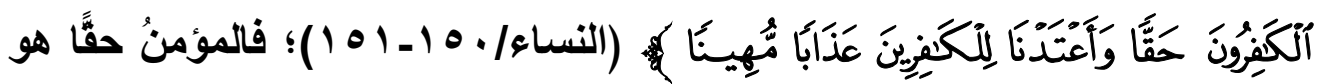

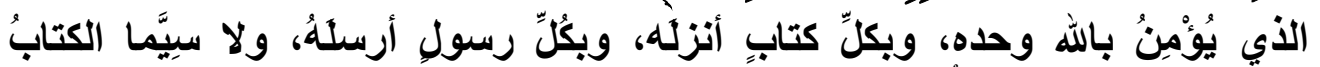

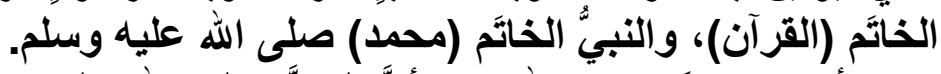

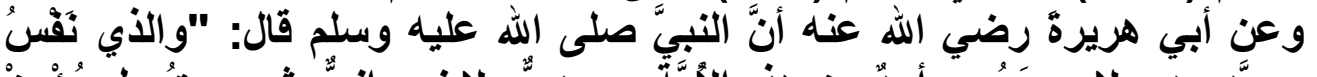

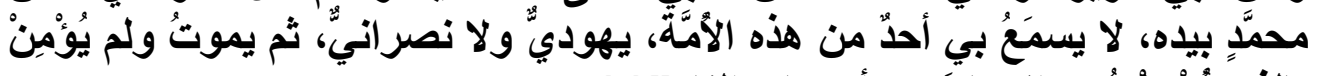

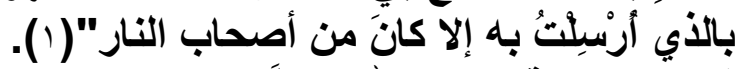

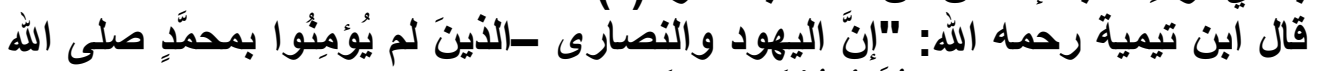

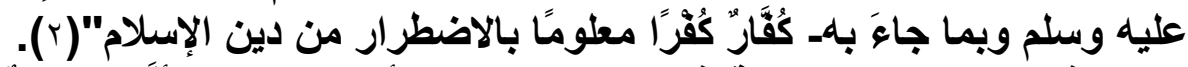

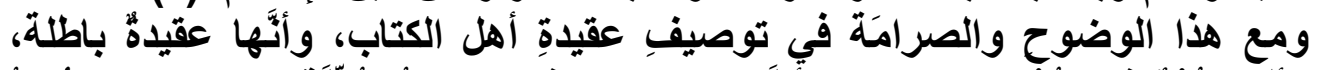

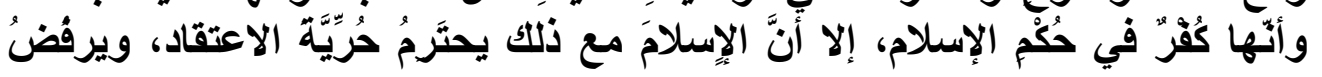

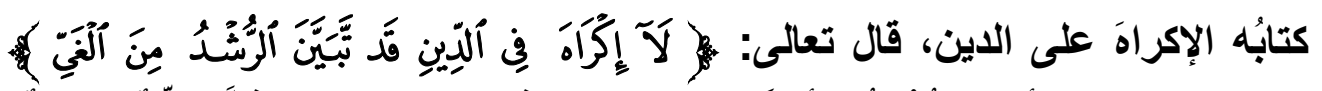

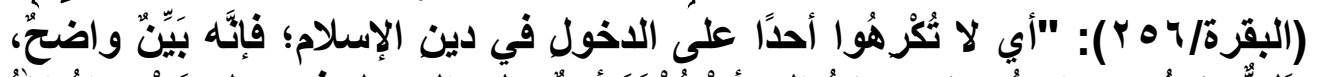

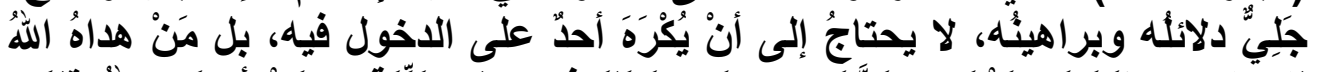

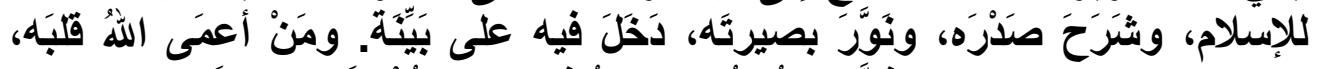

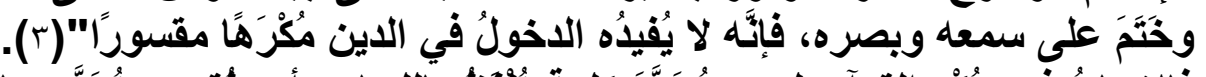

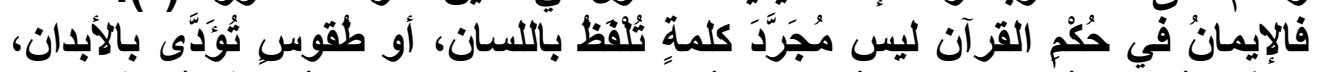

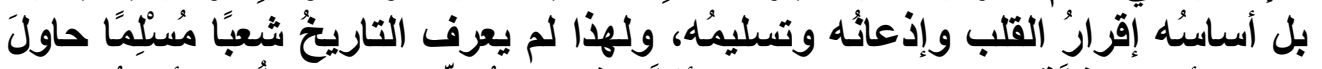

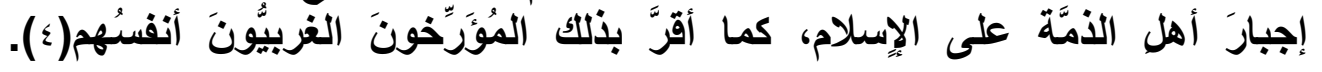

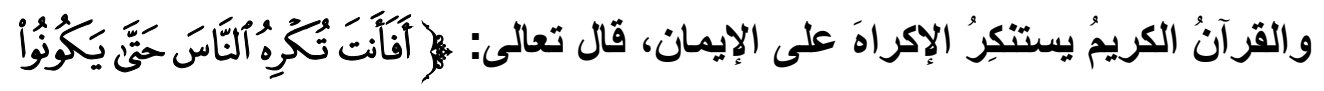

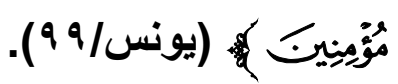

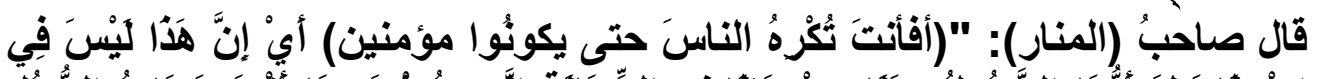

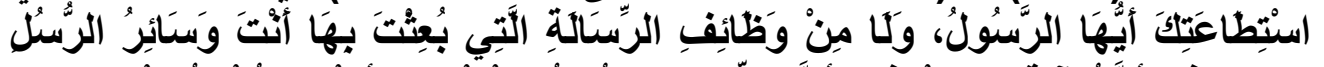

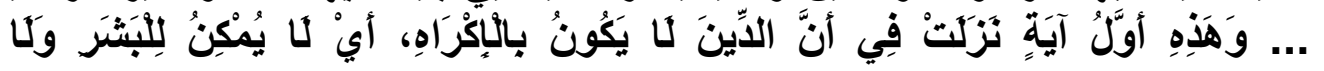

(') أخرجه مسلِّ، كتاب الإِيمان، باب وجوب الإيمان برسالة نبيّنا محمد صلى الله عليه وسلم إلى

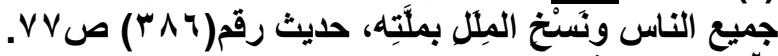

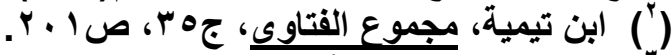

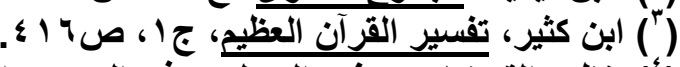
(') ينظر: القرضاوي، غير المسلمين في المجتمع الإسلامي، صب، 


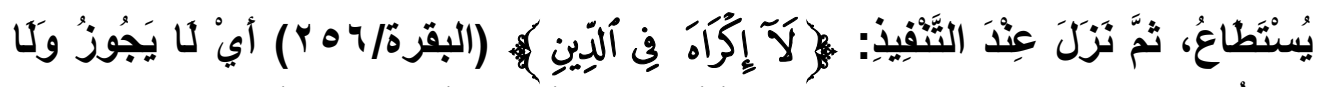

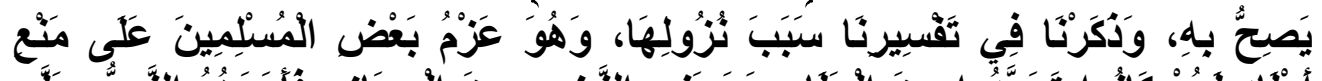

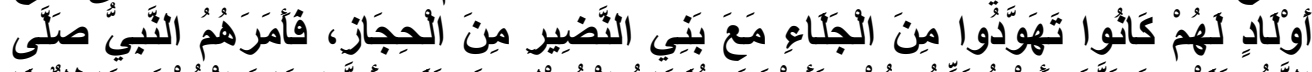

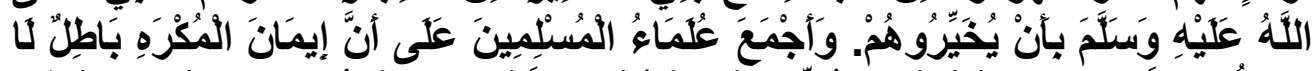

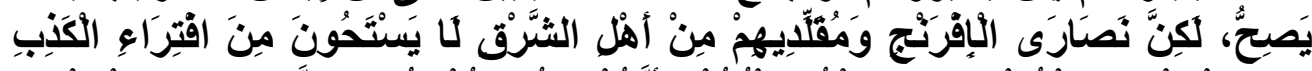

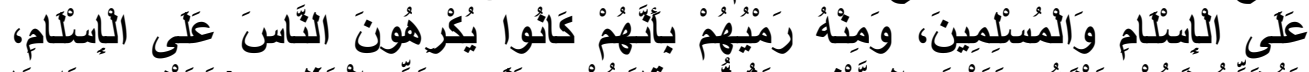

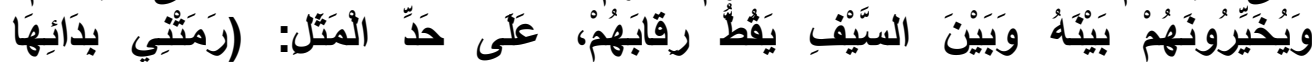

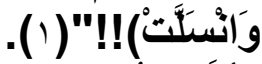

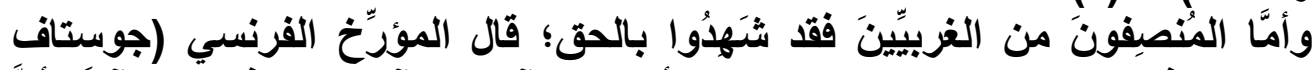

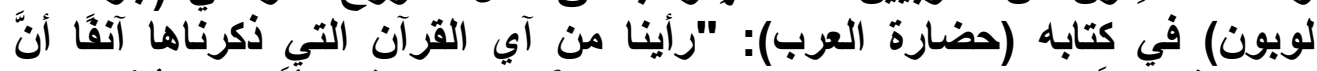

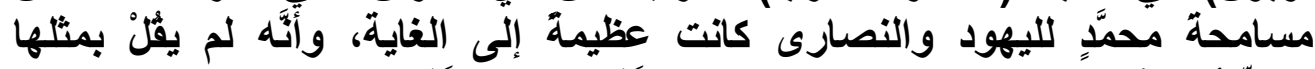

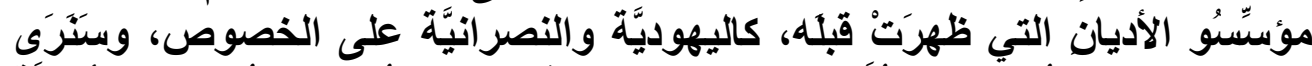

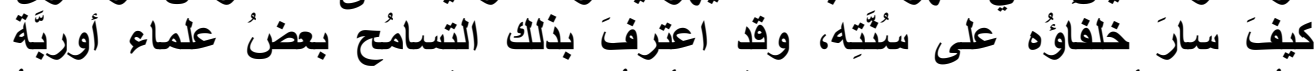

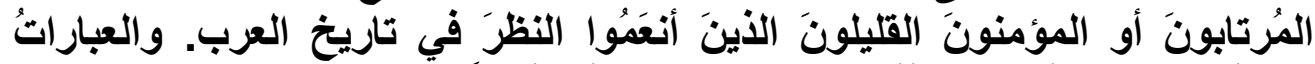

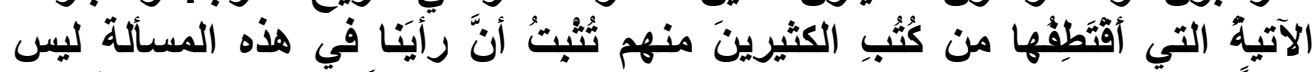

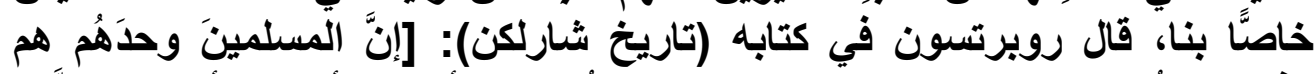

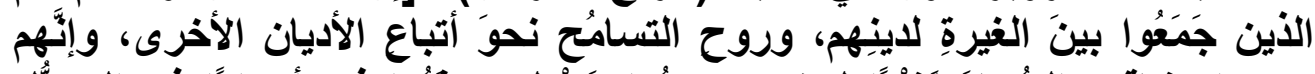

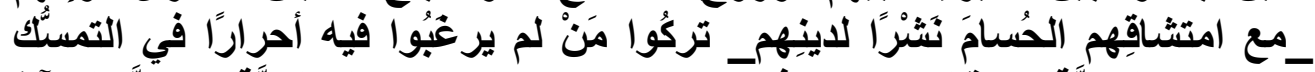

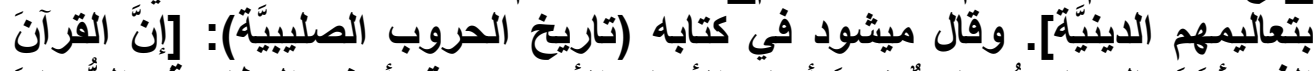

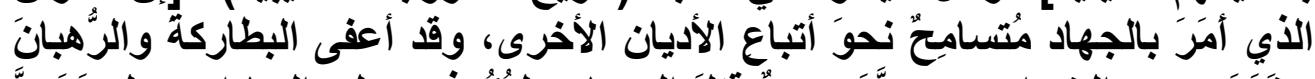

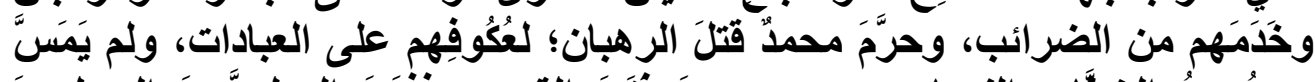

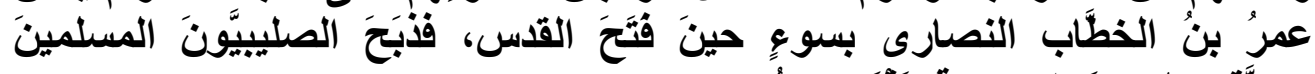

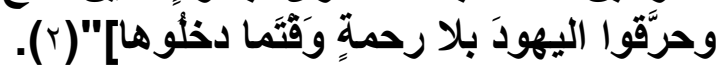

\section{المطلب الثاني (باني}

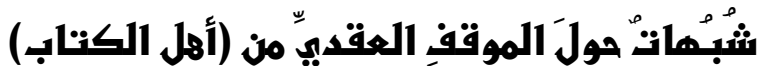

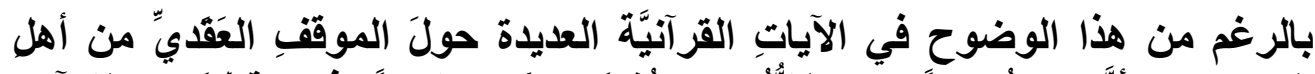

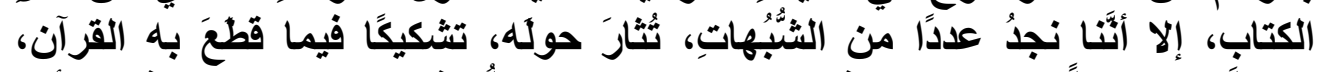

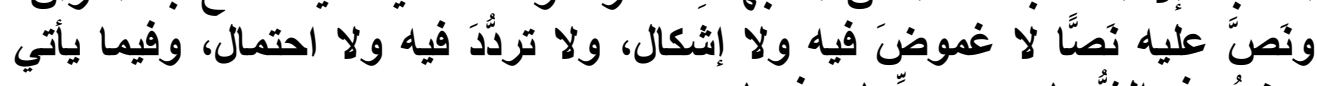

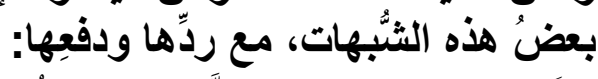

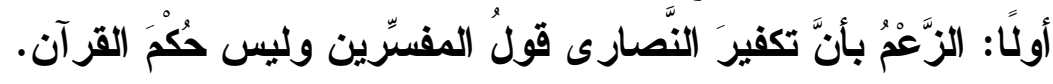

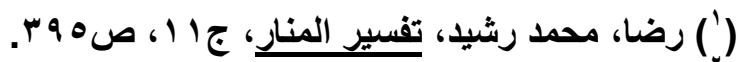

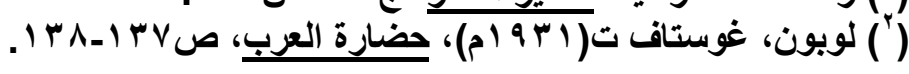




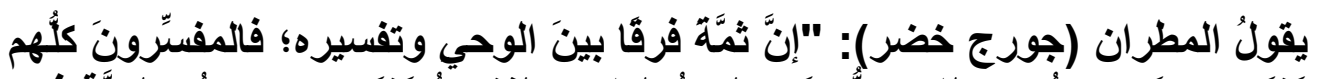

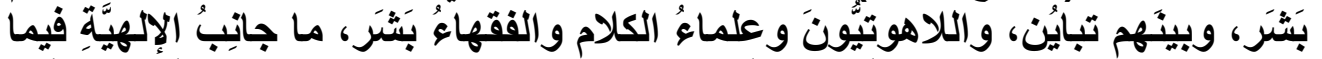

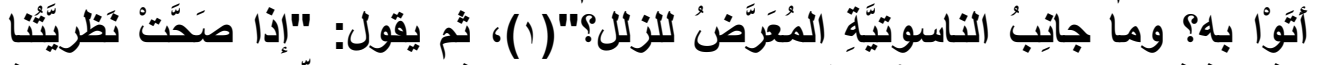

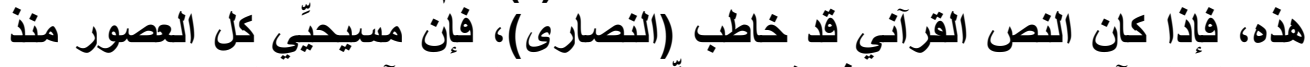

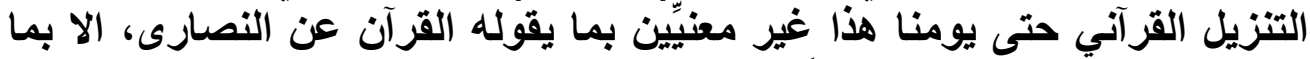

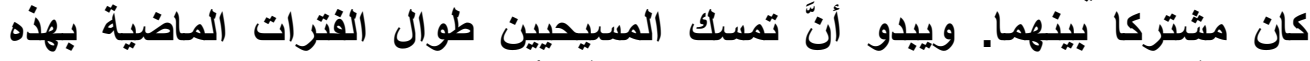

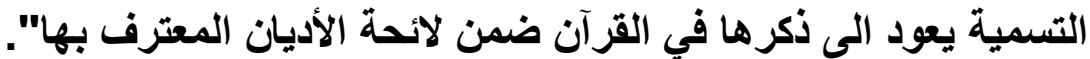

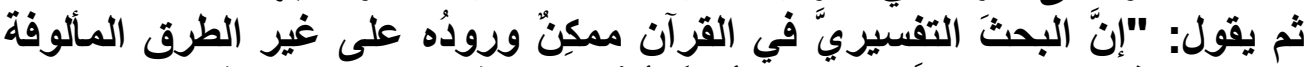

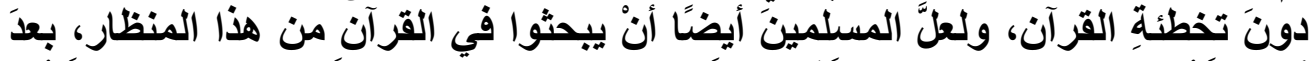

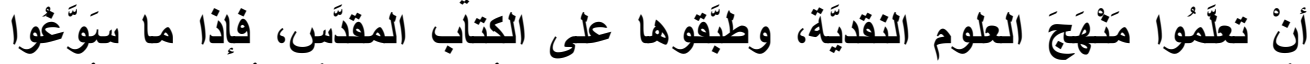

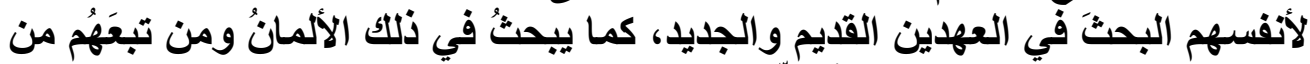

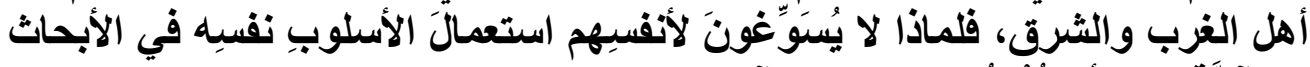

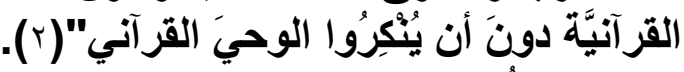

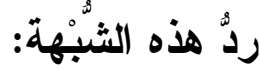

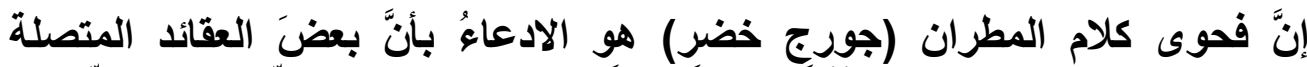

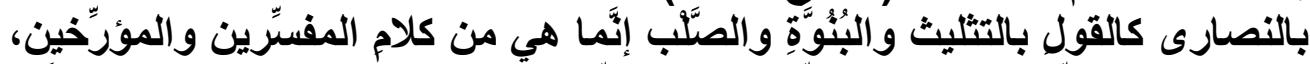

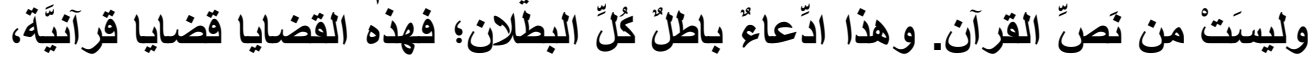

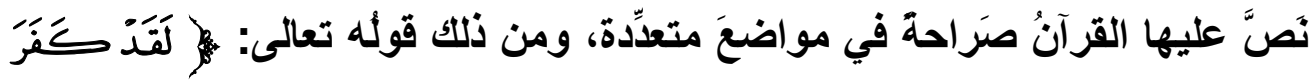

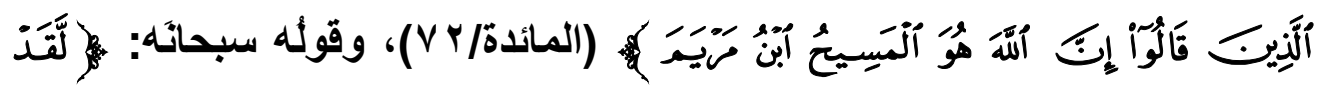

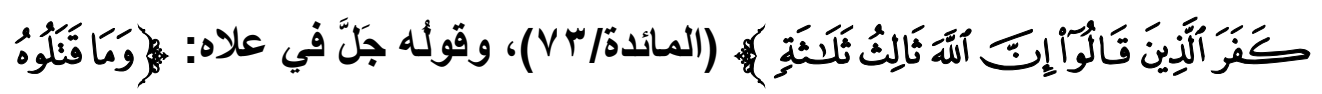

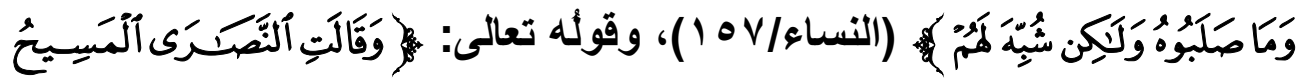

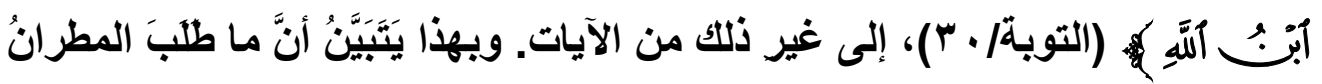

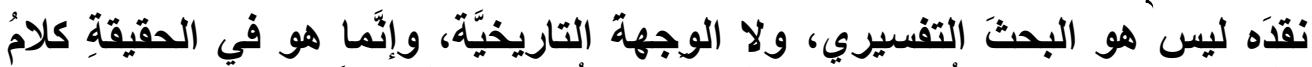

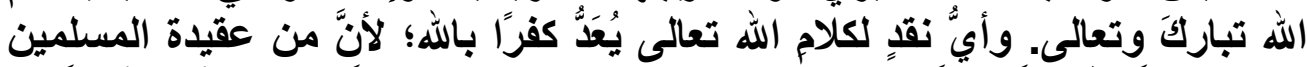

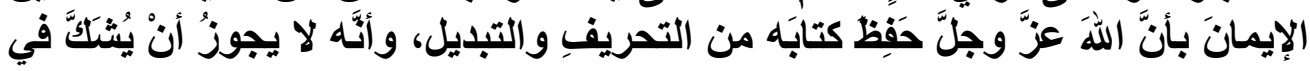

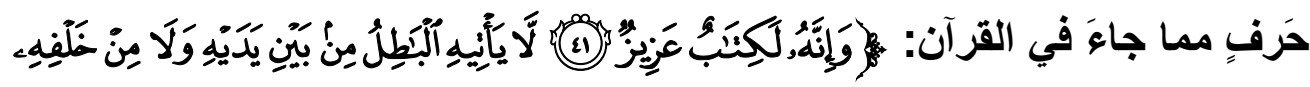

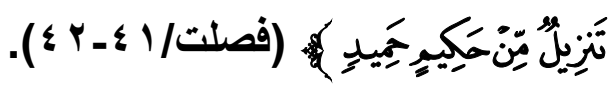

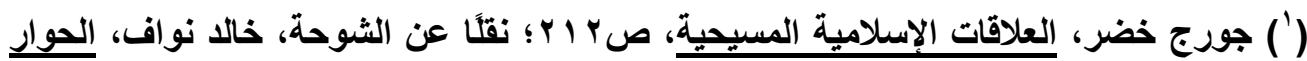

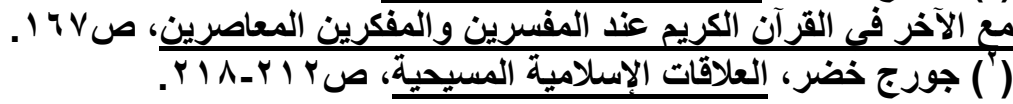




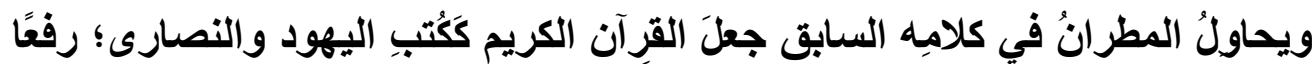

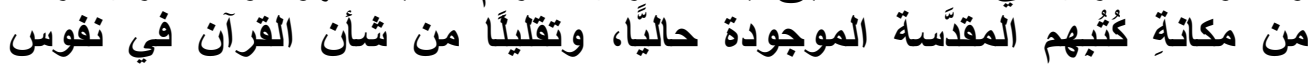

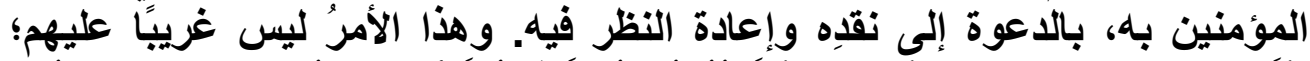

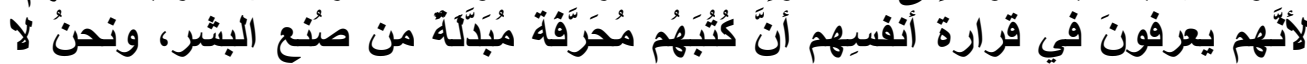

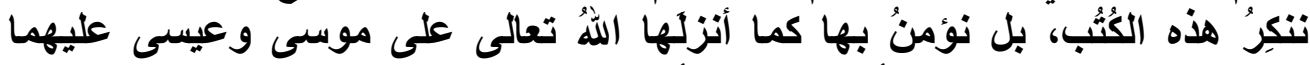

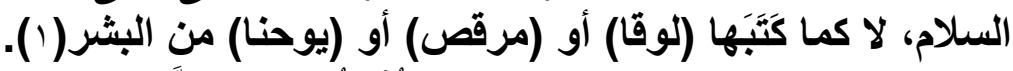

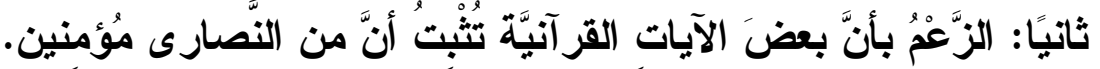

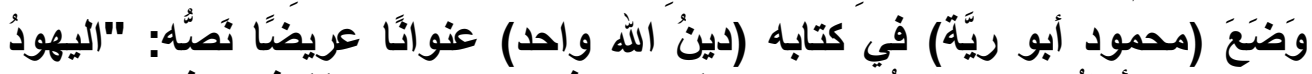

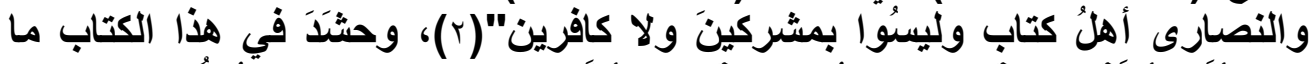

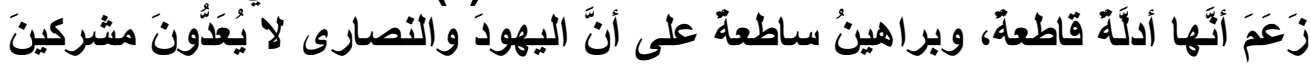

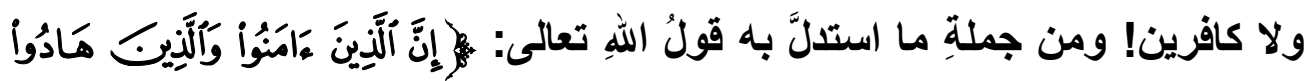

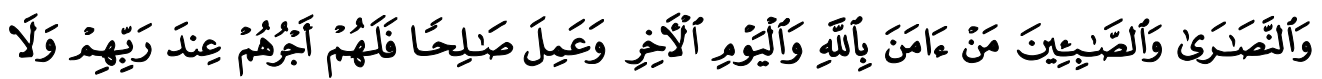

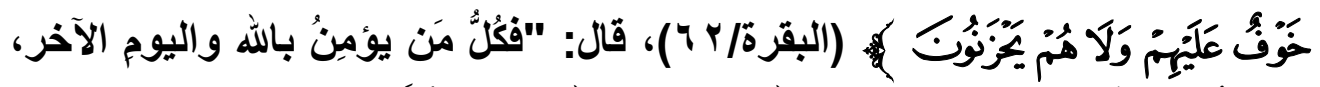

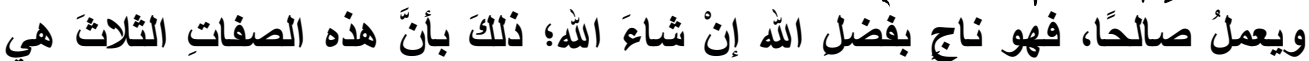

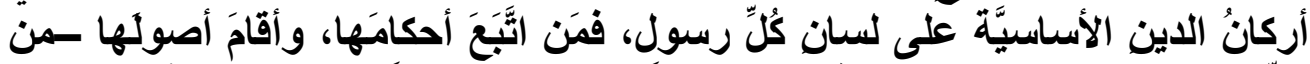

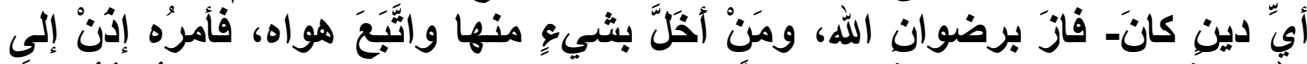

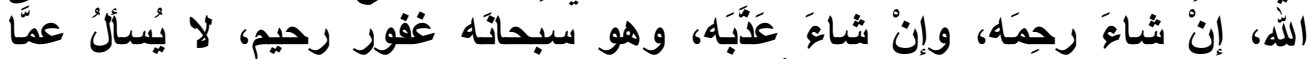

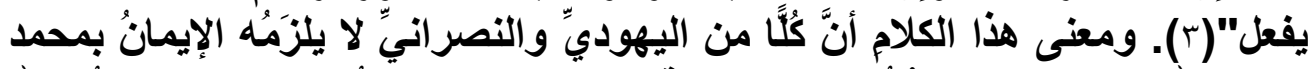

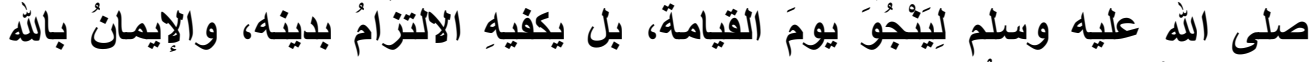

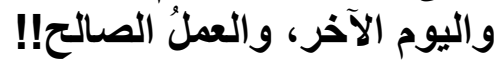

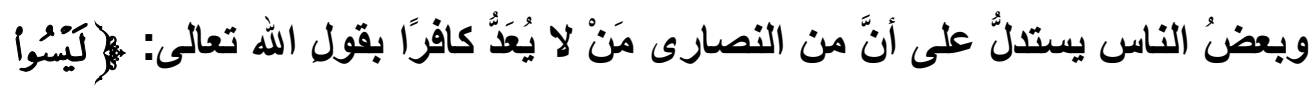

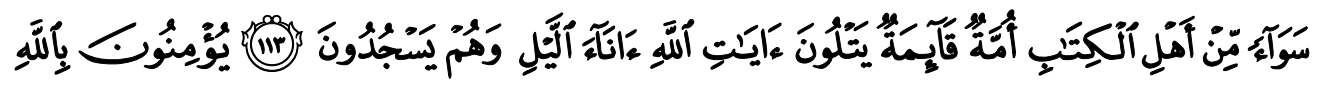

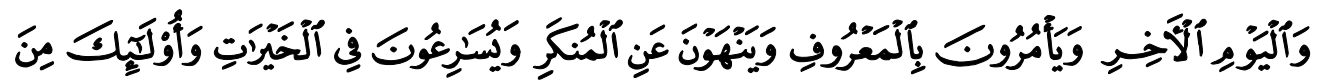

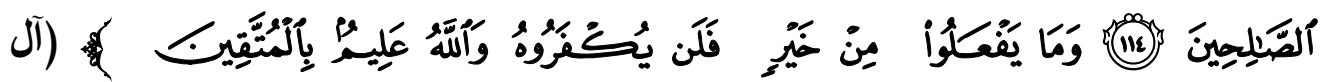

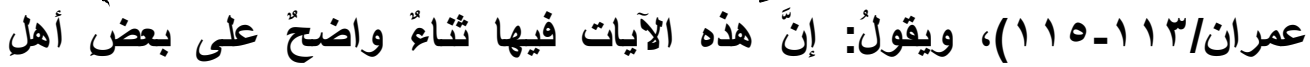

(') ينظر: الثوحة، خالد نواف، الحوار مع الآخر في القرآن الكريح عند المفسرين والمفكرين

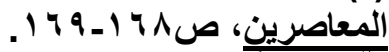

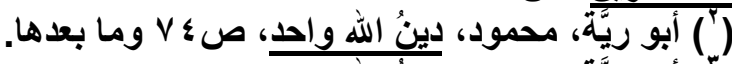

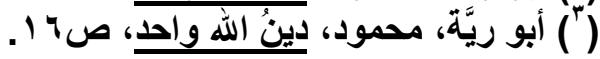


الكتاب، ووصفُّ لهم بالإيمان والتقوى والصلاح، وإذَنْ فليسَ كُلٌّ أهل الكتاب كُهَّارًا،

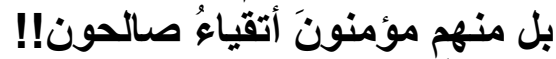

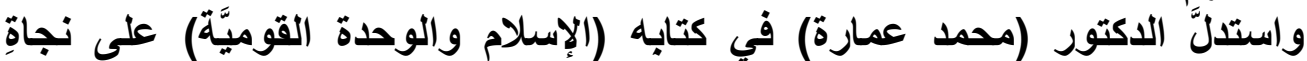

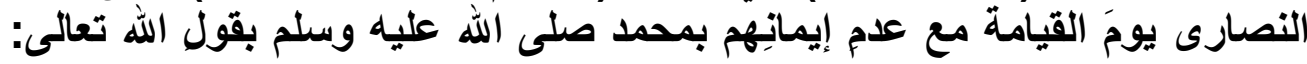

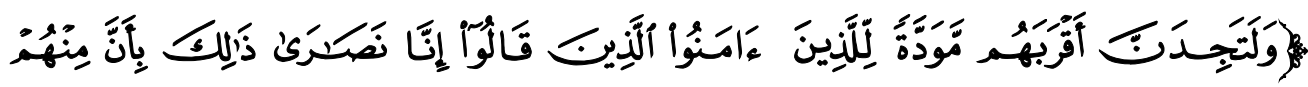

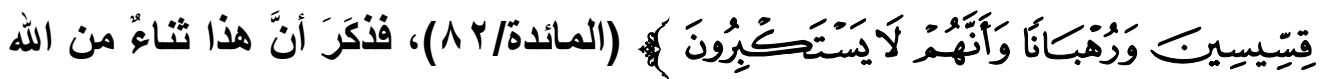

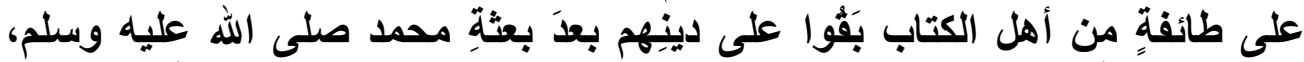

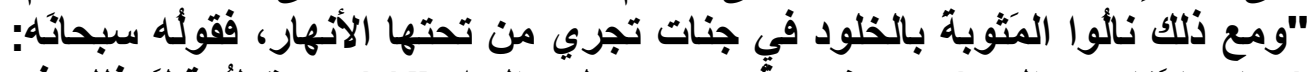

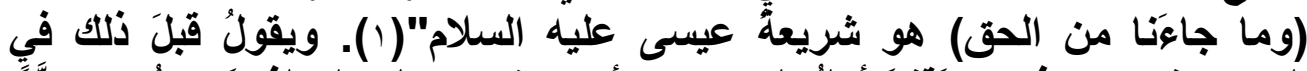

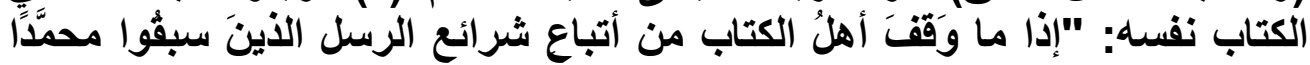

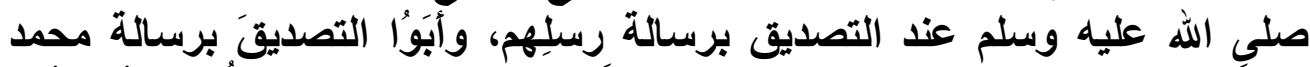

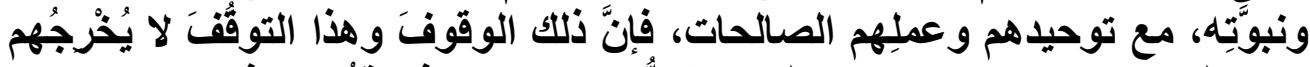

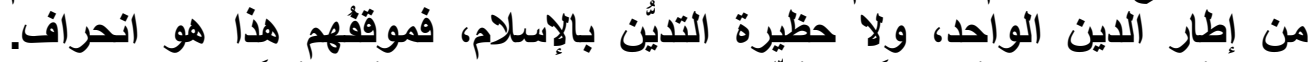

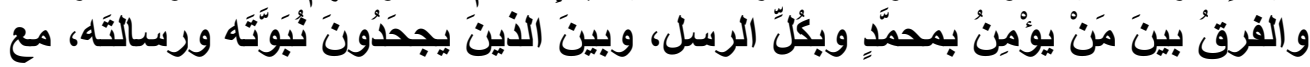

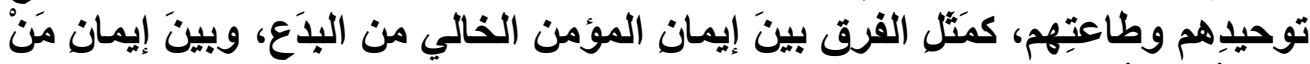

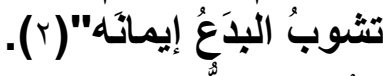

$$
\begin{aligned}
& \text { ردُّ هذه الثَبَّه:ه: }
\end{aligned}
$$

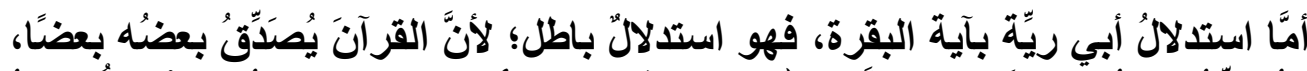

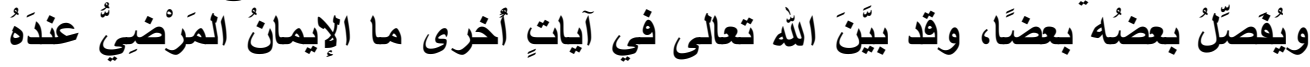

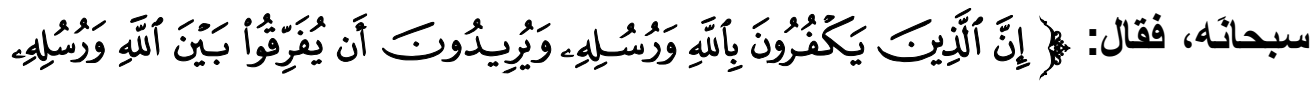

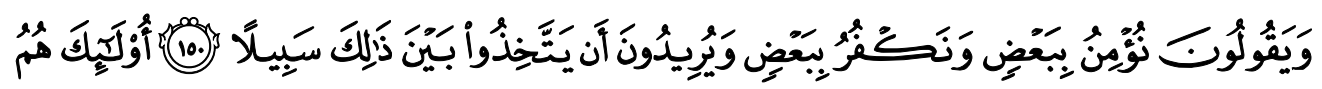

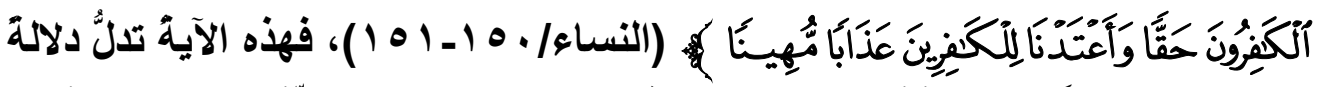

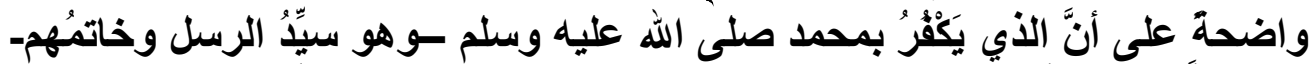

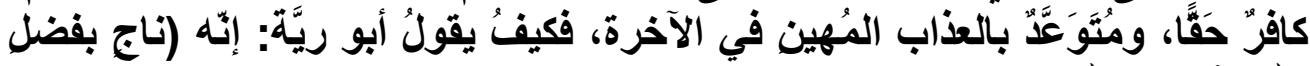
الله إنْ شَاءَ الله)؟؟إِ

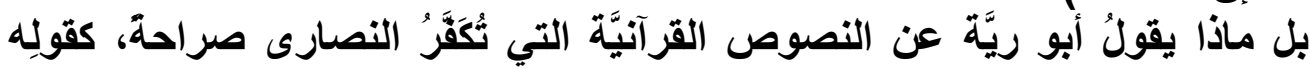

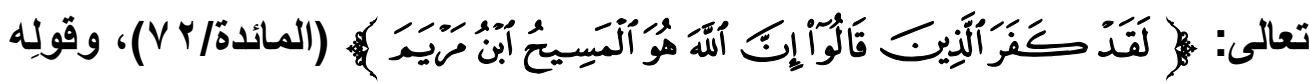

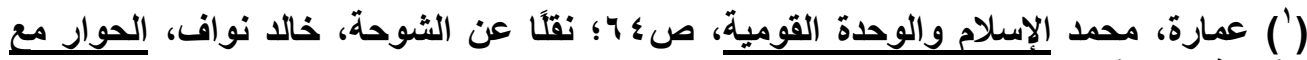

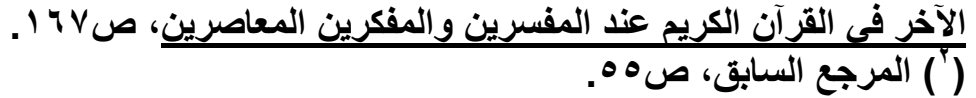




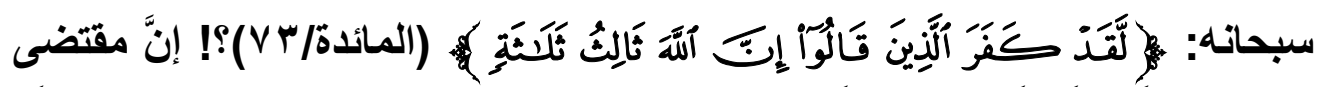

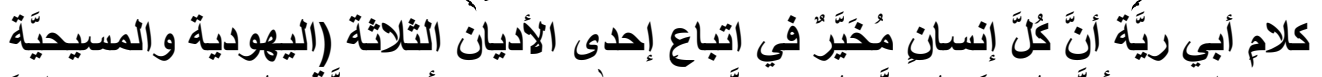

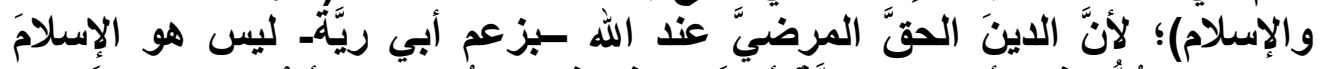

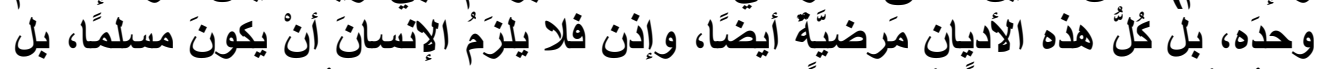

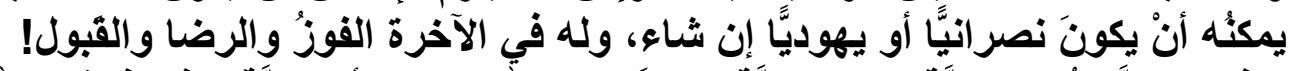

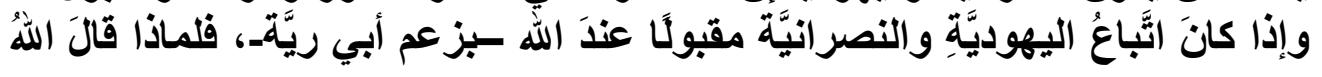

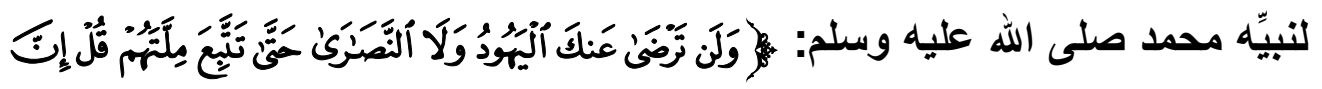

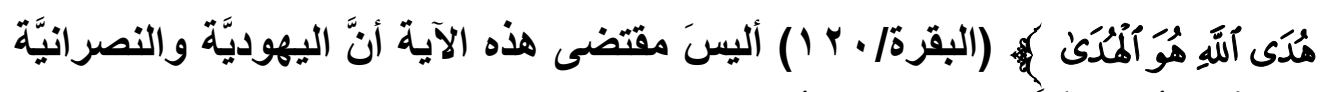

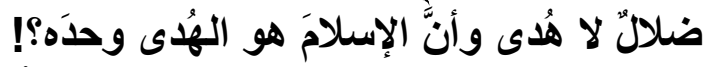

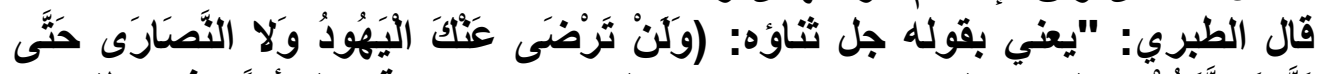

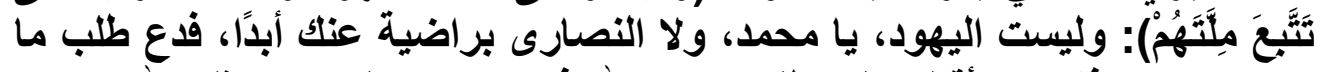

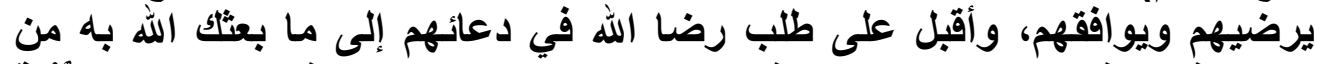

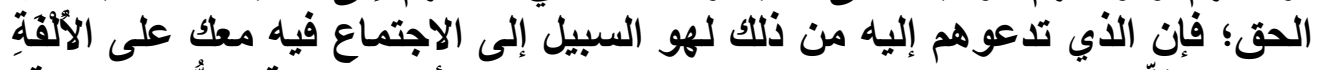

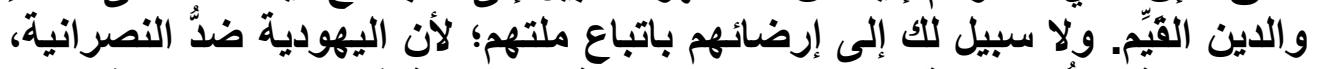

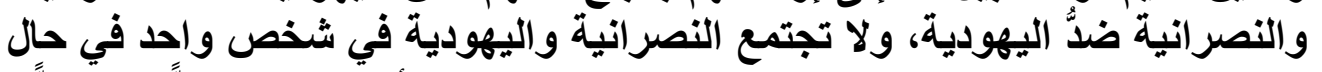

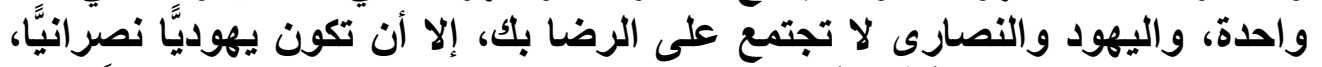

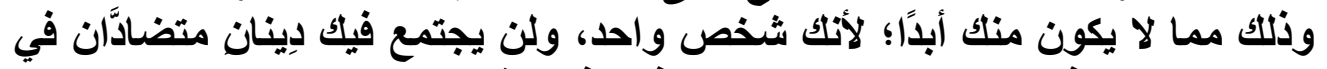

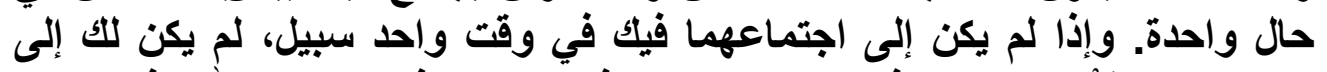

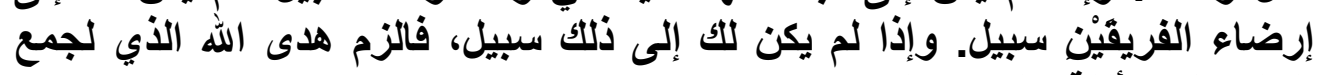

الخلق إلى الألفة عليه سبيلِ" (1).

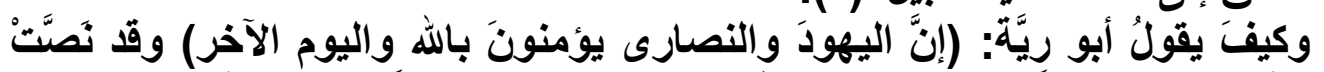

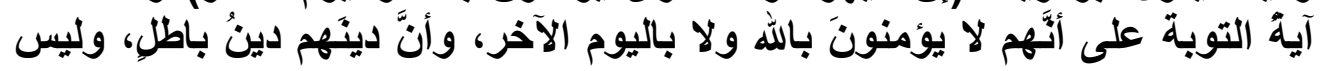

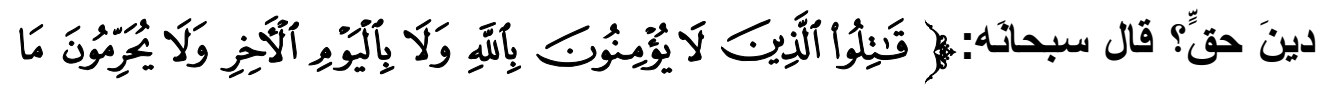

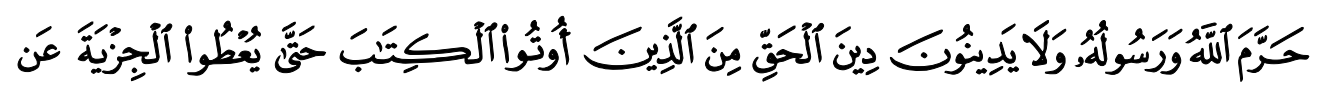

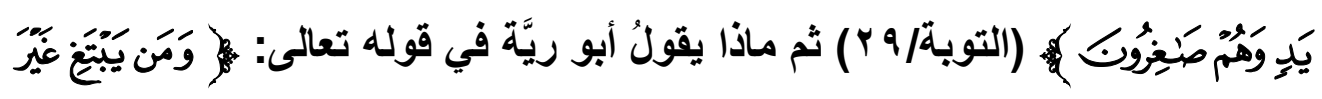

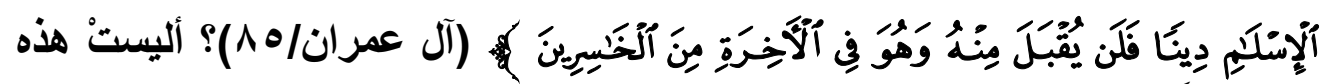

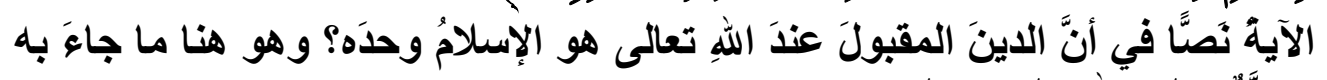

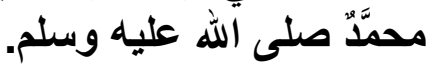




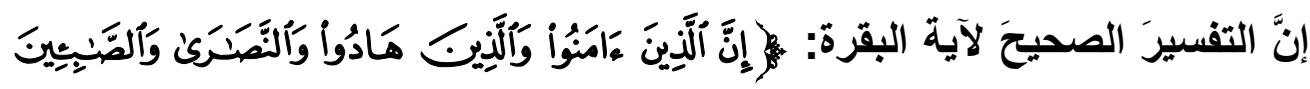

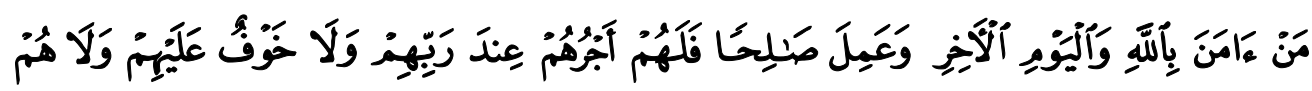

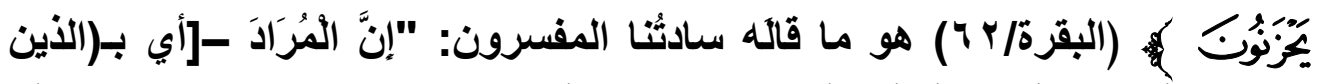

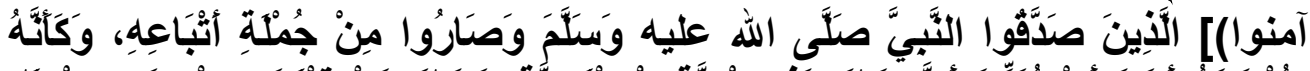

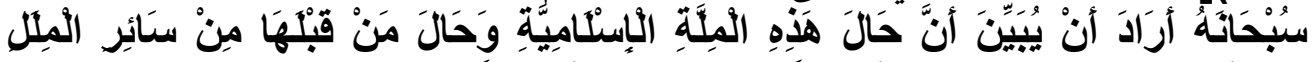

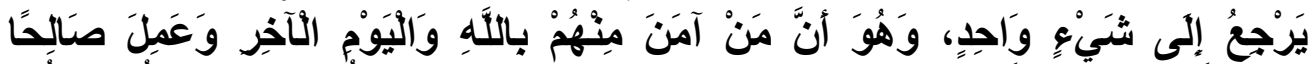

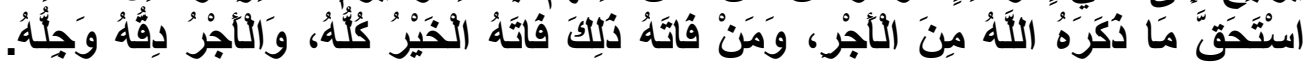

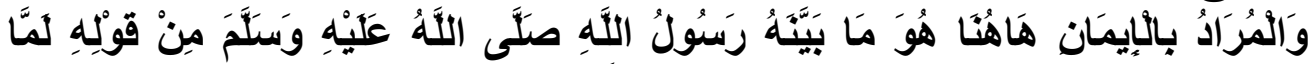

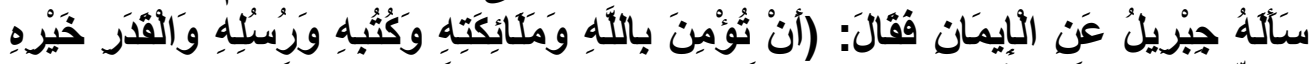

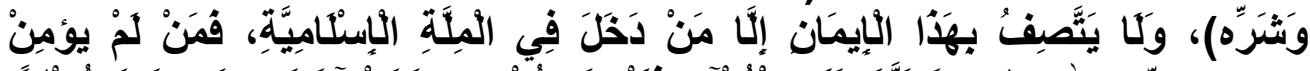

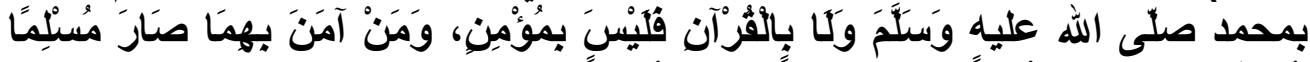

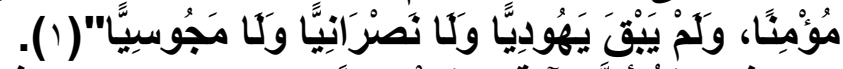

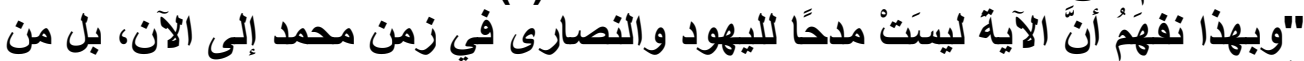

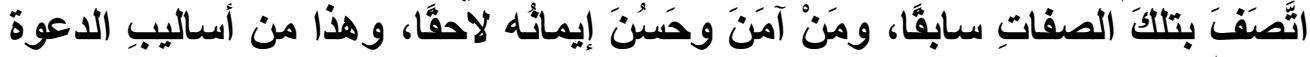

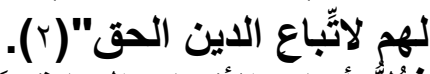

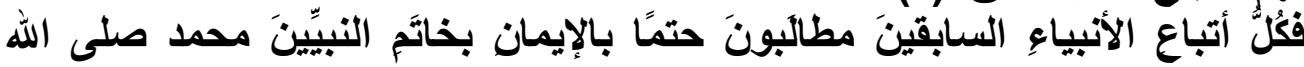

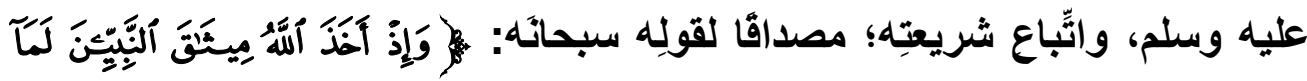

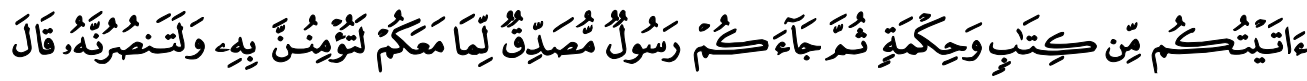

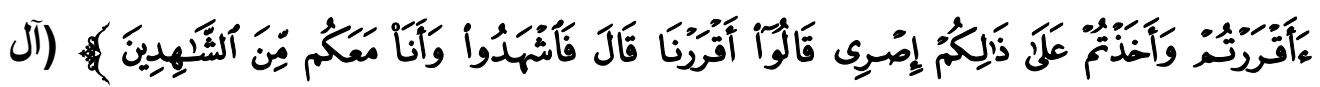

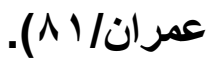

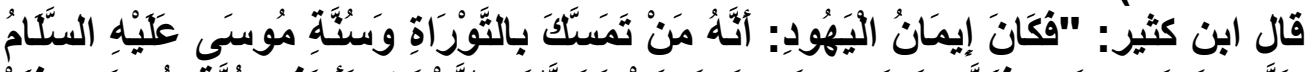

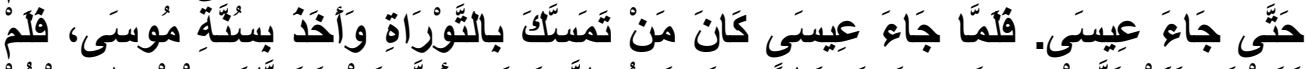

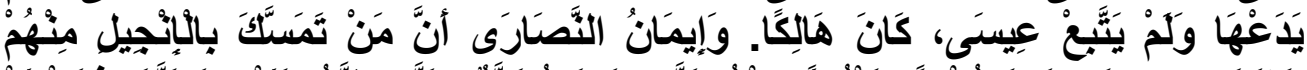

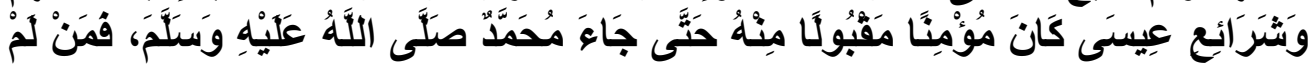

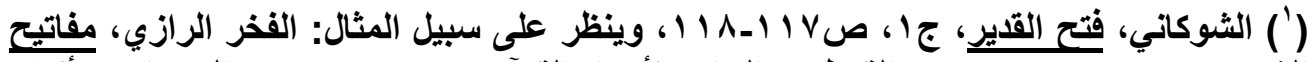

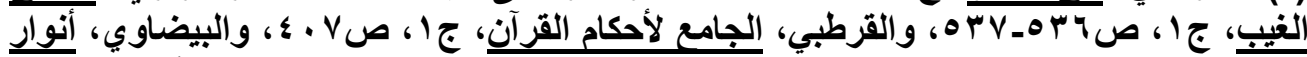

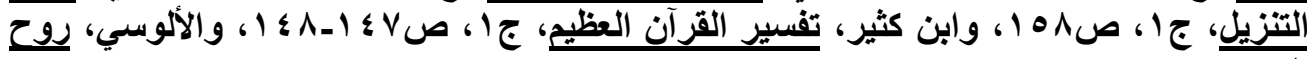

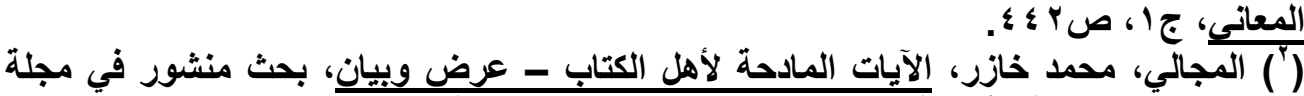

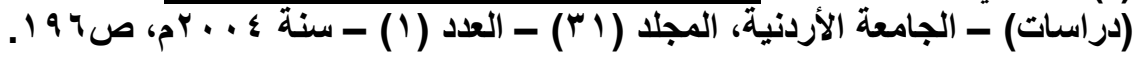




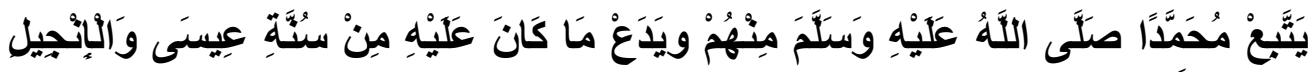

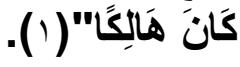

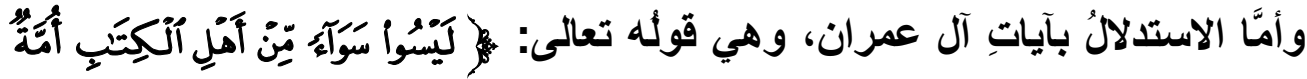

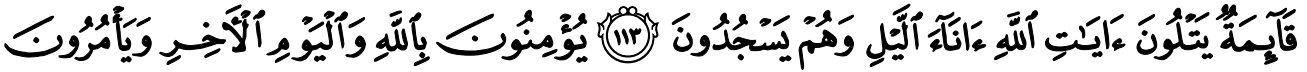

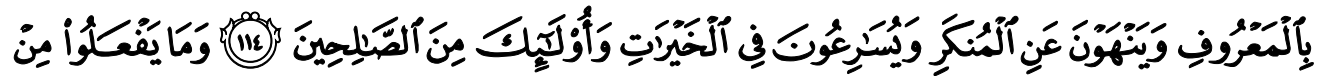

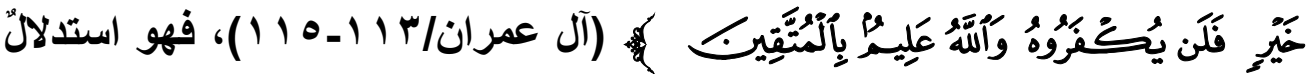

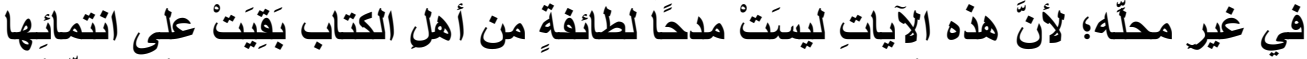

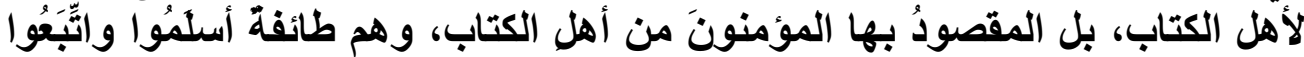

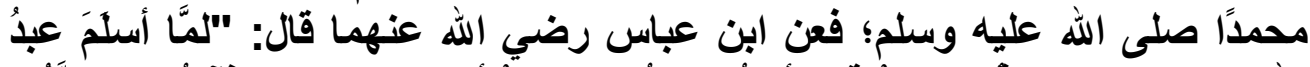

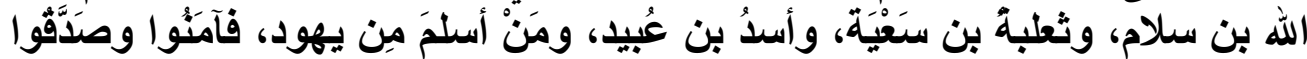

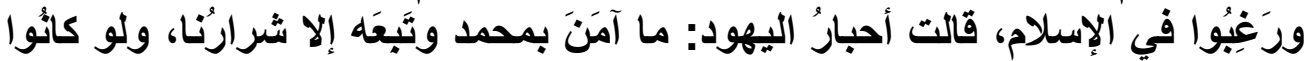

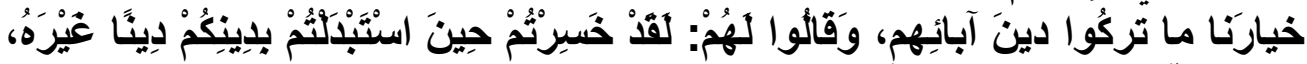

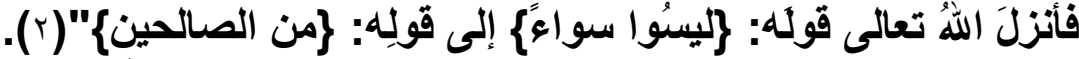

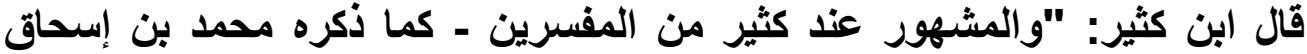

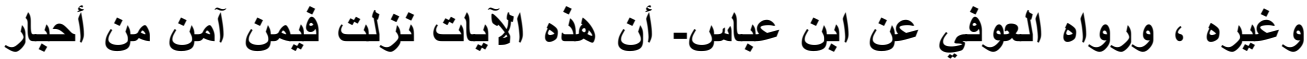

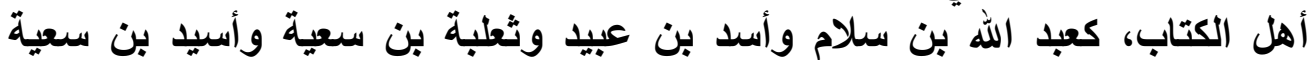

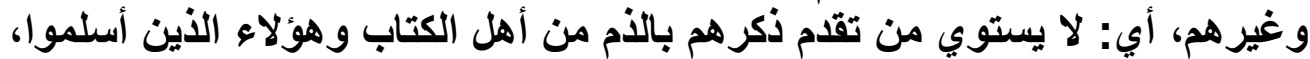

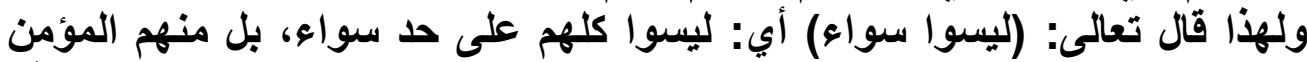

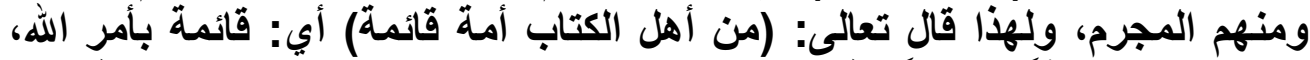

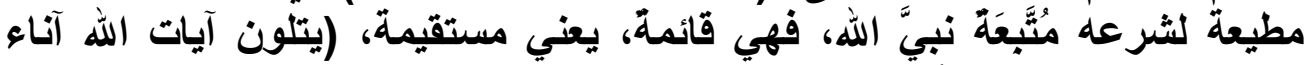

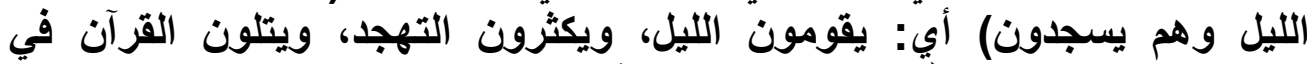

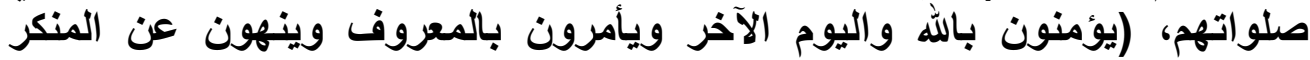
ويسارعون في الخيرات وأولئلك من الصالحين) وهؤلاء هم المذكورون في آخر

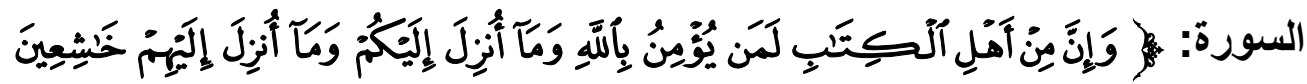

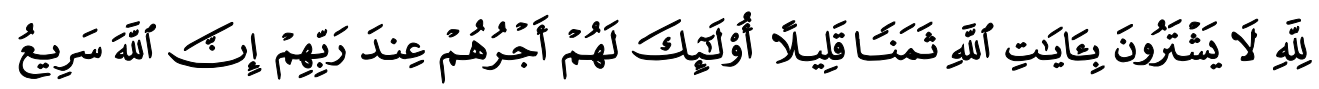

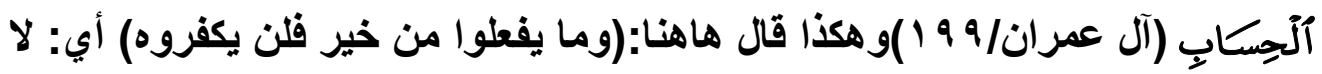

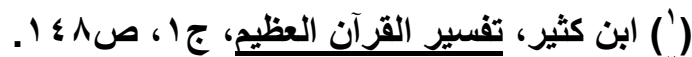

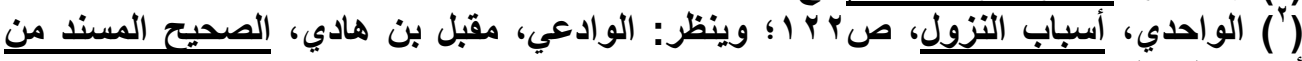

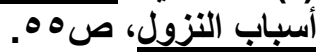


يضيع عند الله بل يجزيكم به أوفر الجزاء، (والله عليم بالمتقين) أي: لا يخفى عليه عمل عامل، ولا يضيح لايه أجر من أحسن عملَّا" (1).

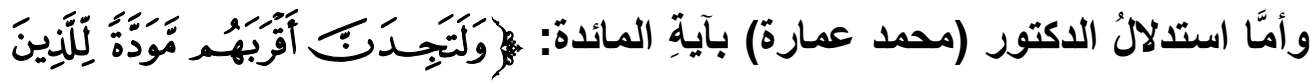

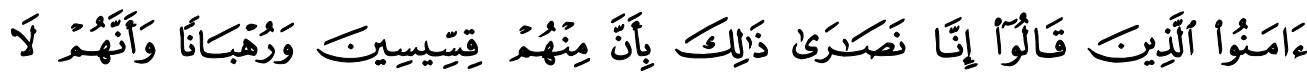

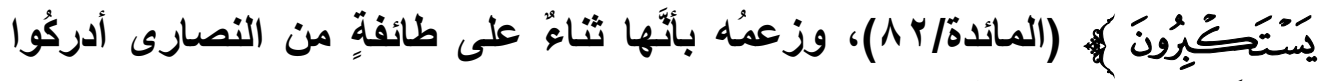

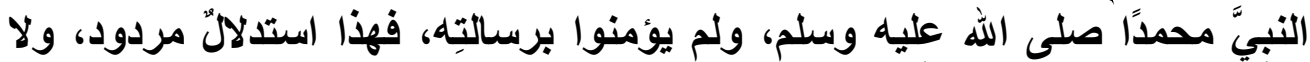

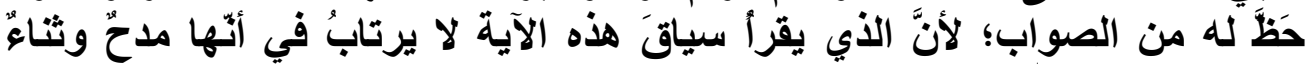

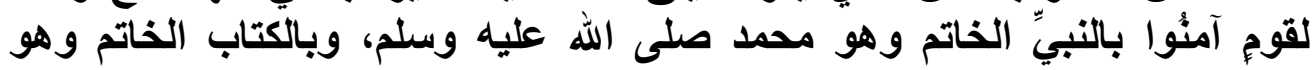

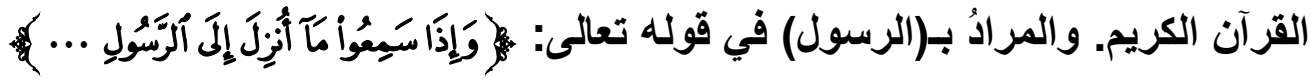

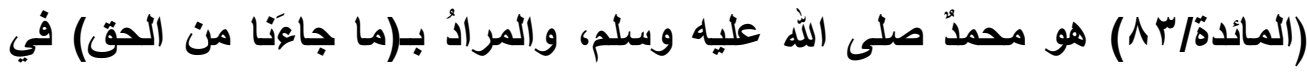

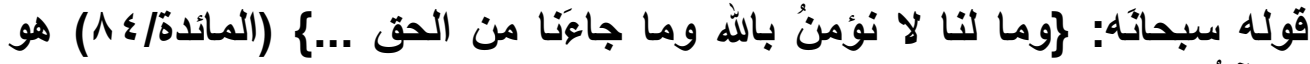

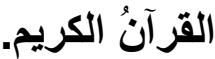

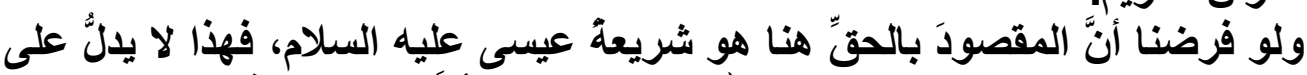

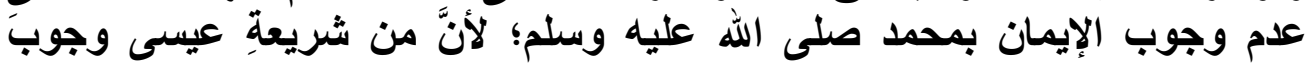

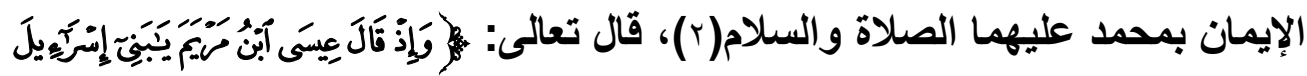

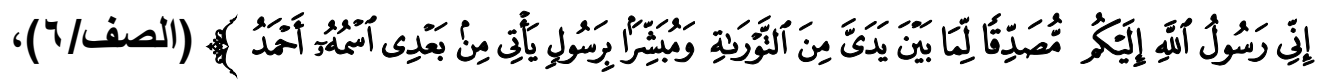

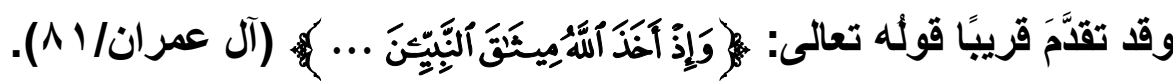

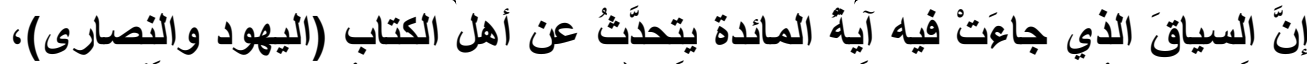

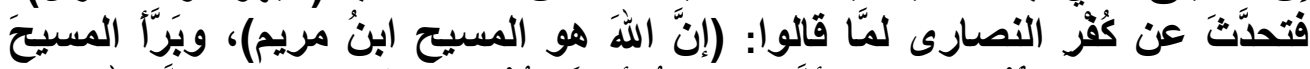

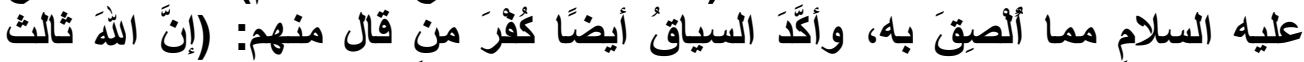

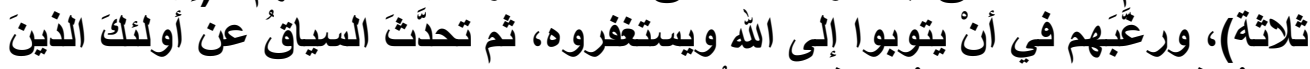

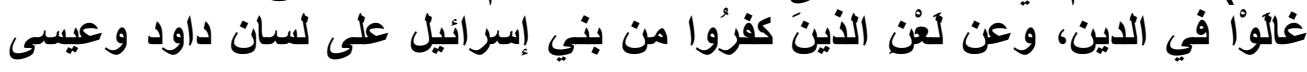

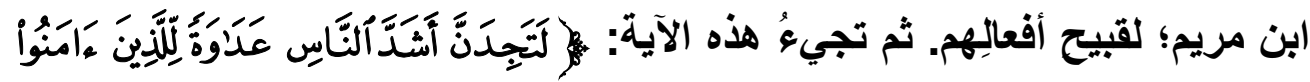

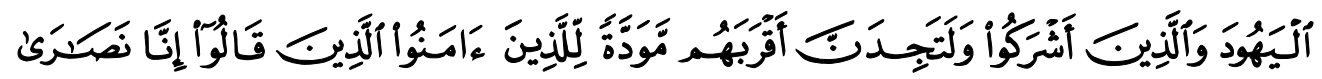

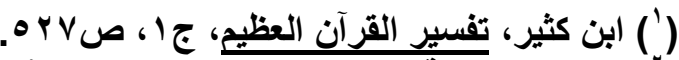

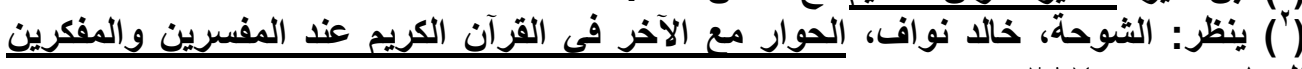

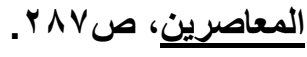




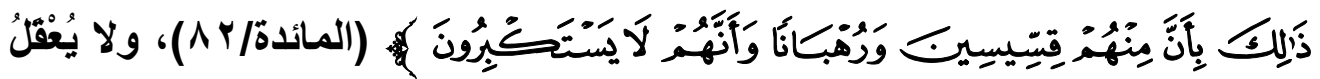

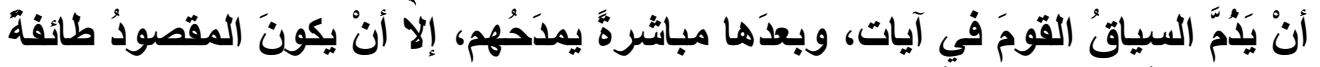

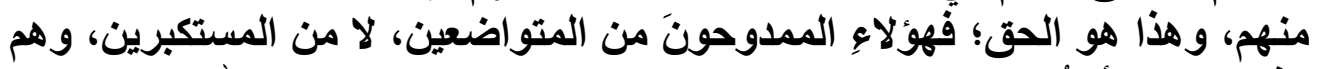

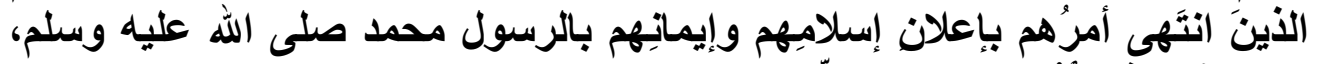

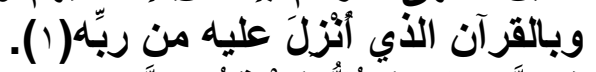

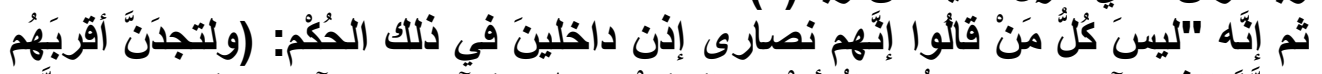

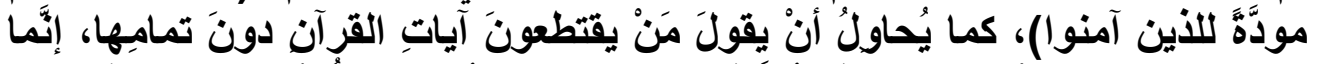

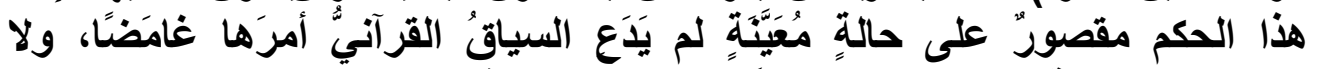

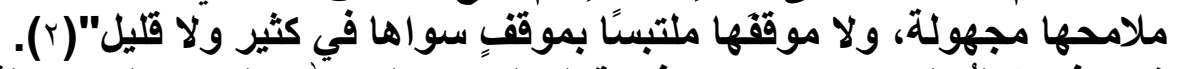

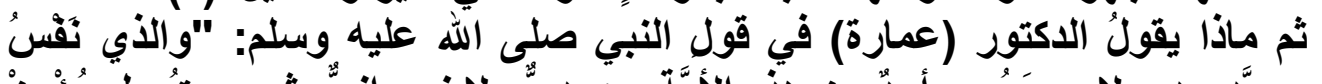

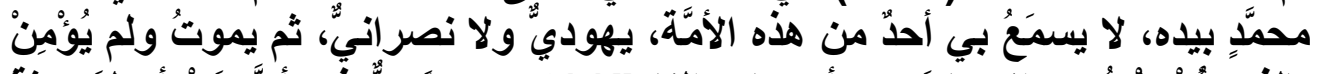

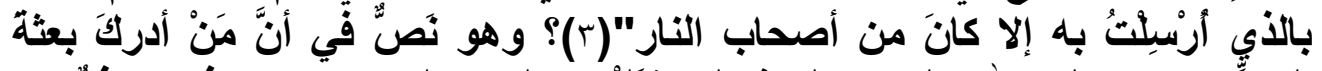

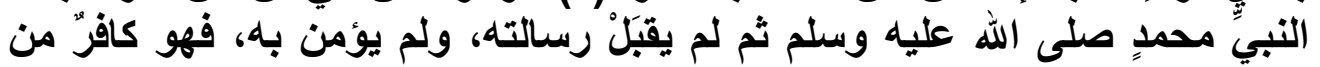

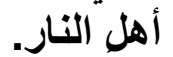

\section{المبمث الثاني

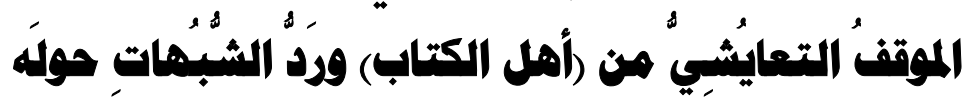

$$
\text { المطلب الأول }
$$

\section{بيانُ القرآن الموقفِ التعايُشُشيِّ من (أهل الكتناب)}

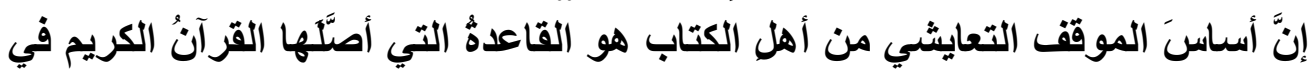

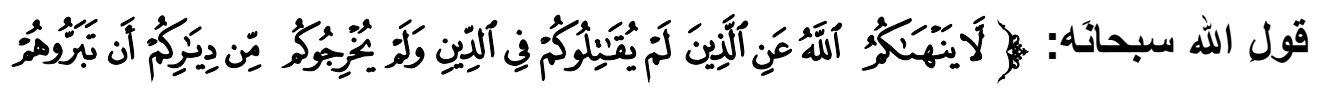

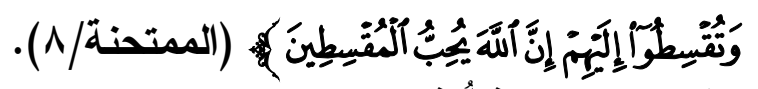

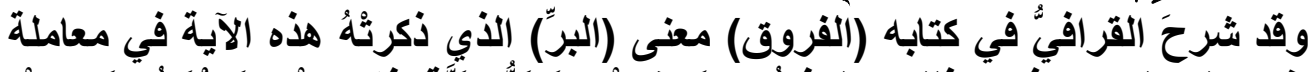

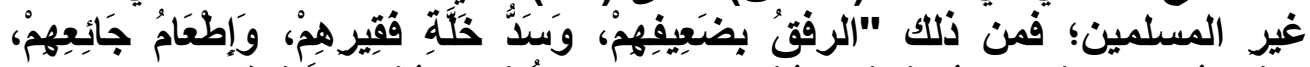

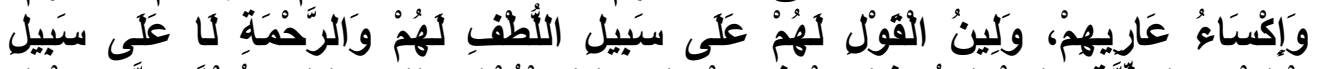

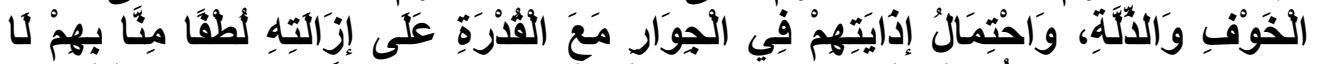

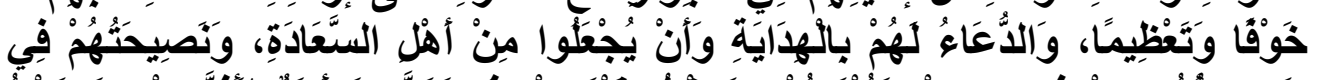

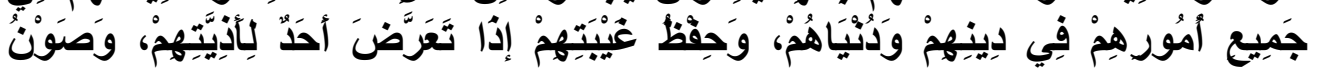

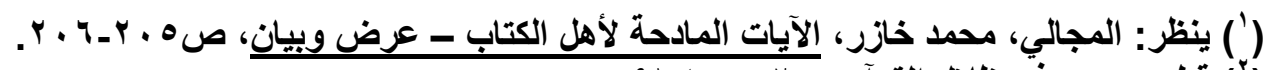

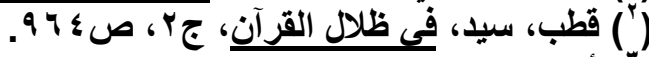

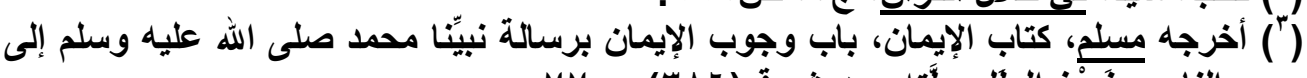

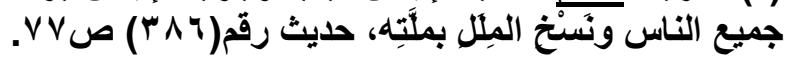




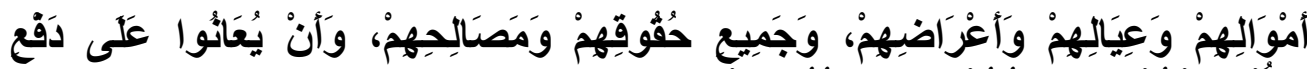

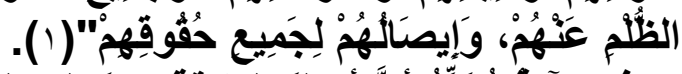

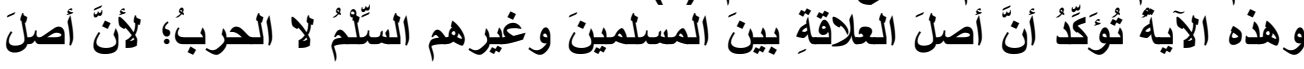

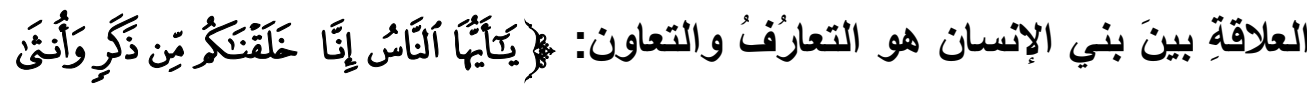

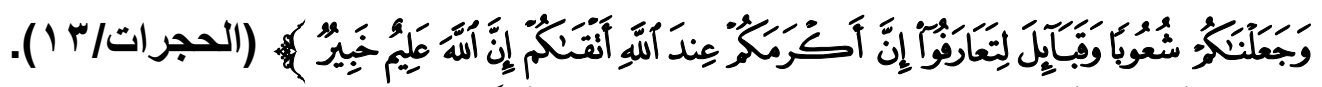

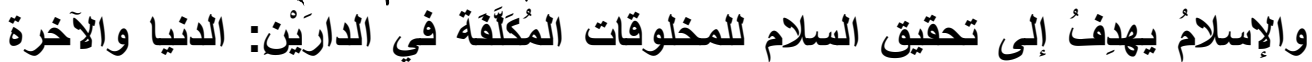

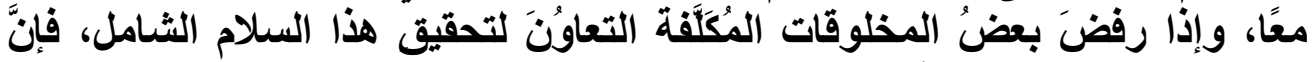

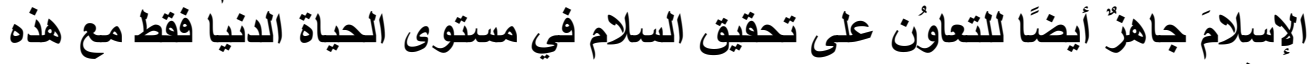

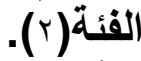

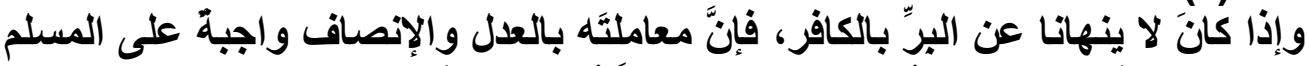

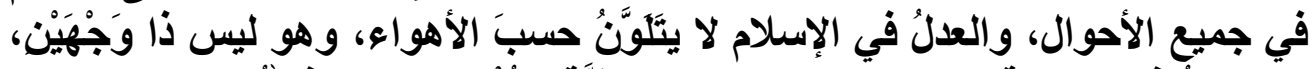

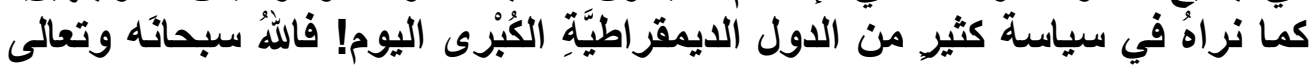

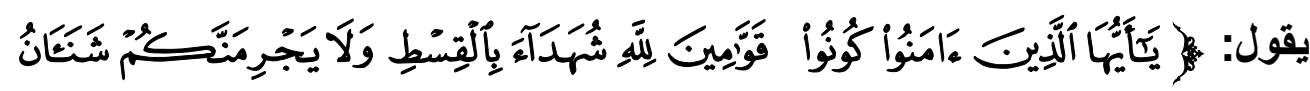

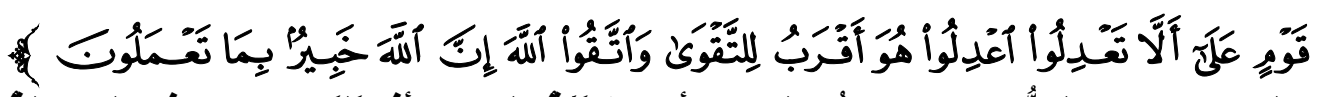

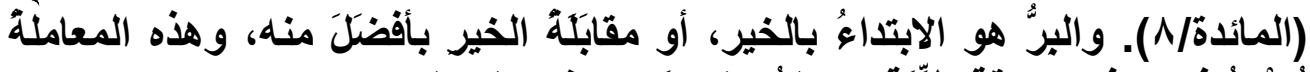

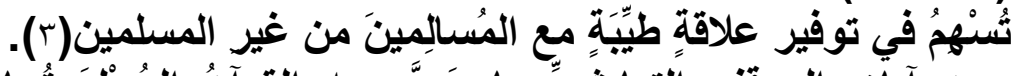

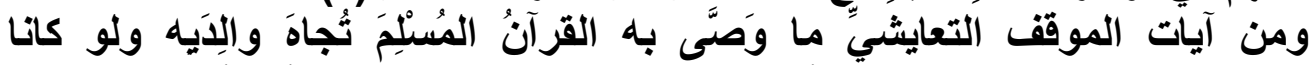

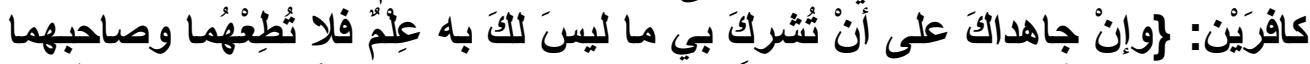

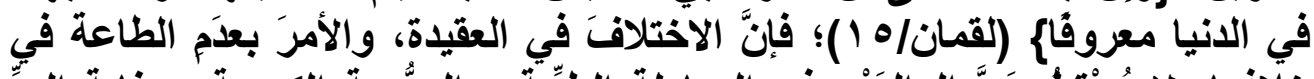

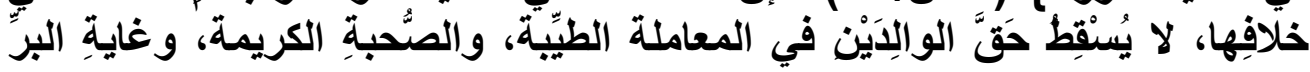

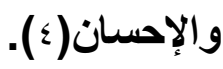

ومن آيات الموقف التعايشي أيضًا ما وصفَ به القرآنُ الأبرارَ بقوله تعالى:

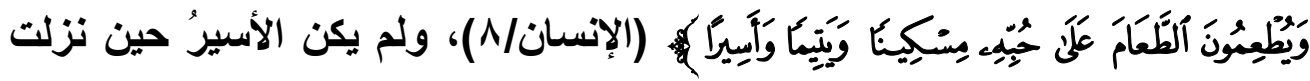

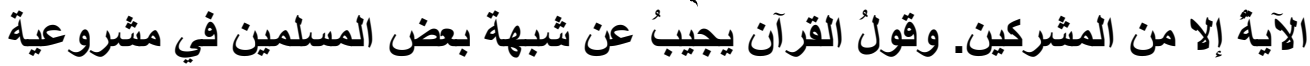

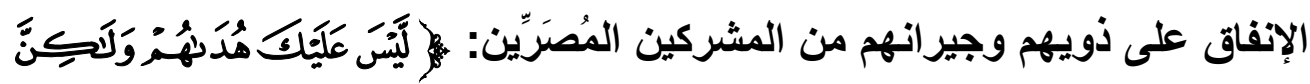

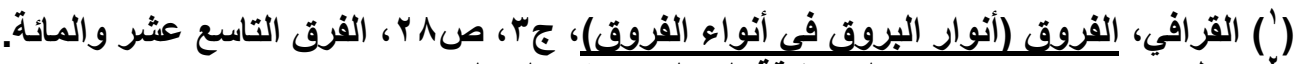

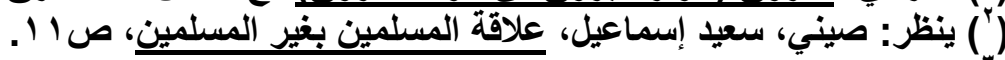

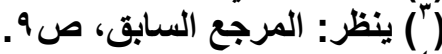

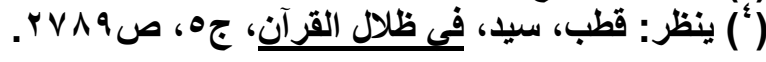




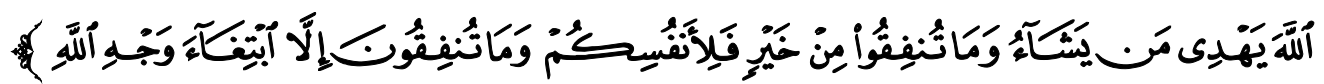

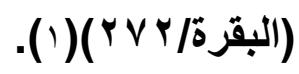
وقد ذكرَ بعضُ علماء الإسلام أنَّ أسساسَ النظرة المُتسامحَحة التي تسودُ المسلمين في معاملة مخالفيهم في الدين يرجعُ إلى الأفكار والحقائق الناصعة التي غُرَسَنَها

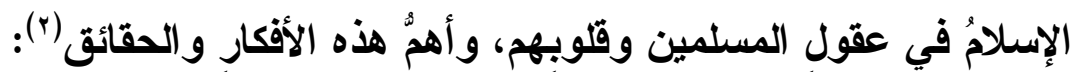

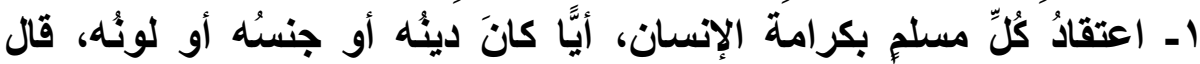

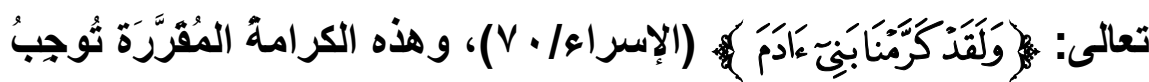

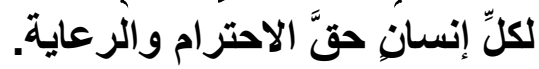

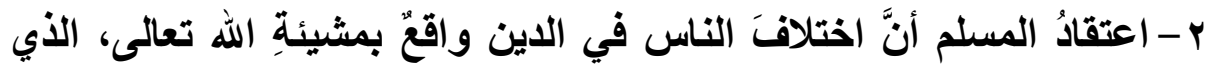

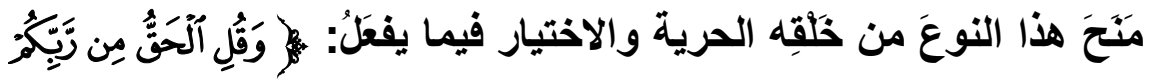

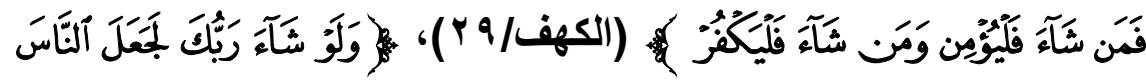

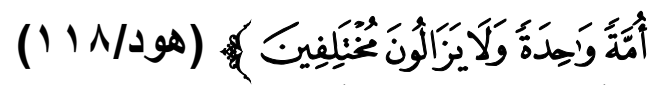

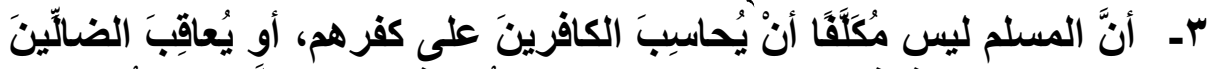

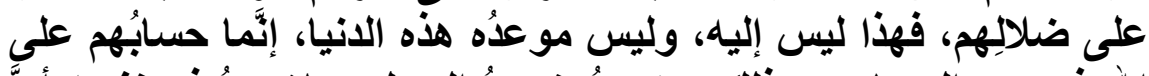

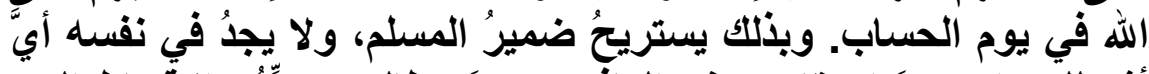

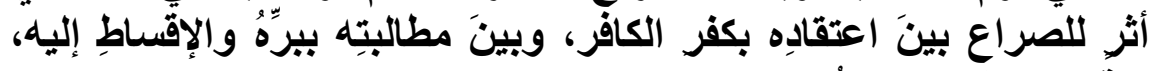

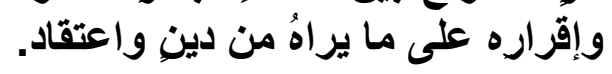

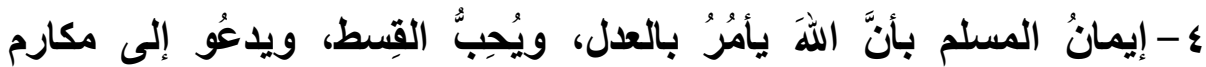

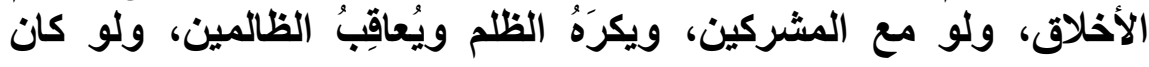

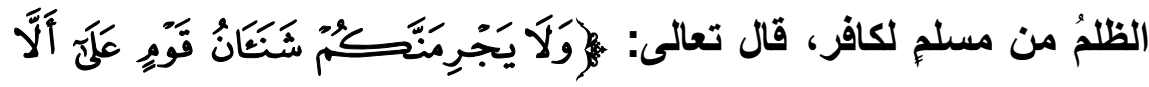

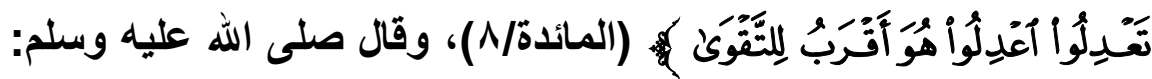

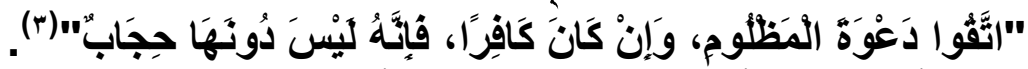

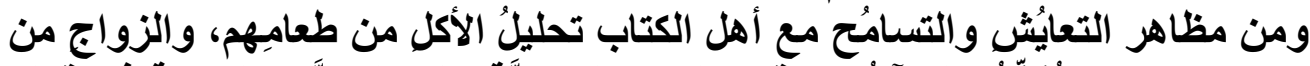

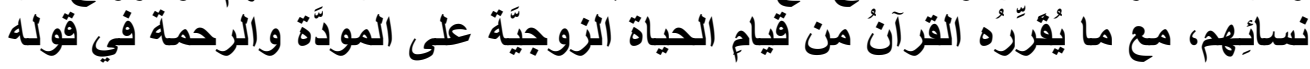

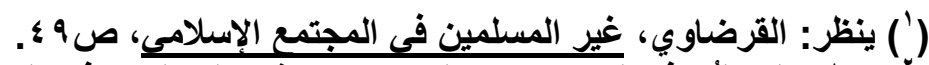

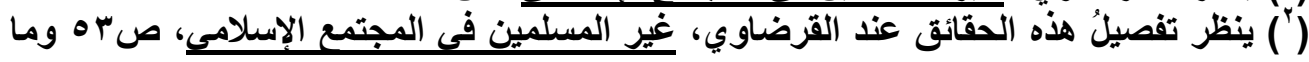

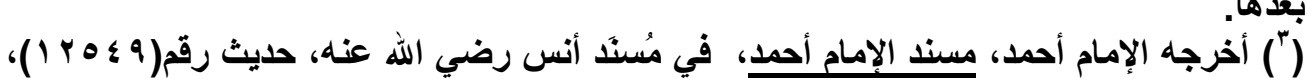

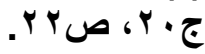




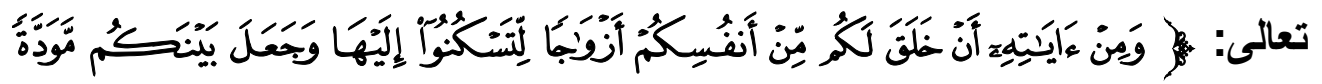

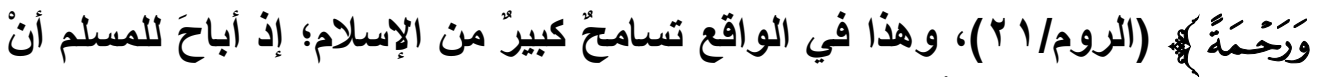

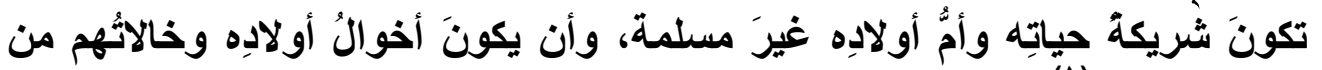

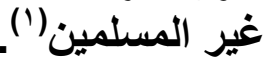

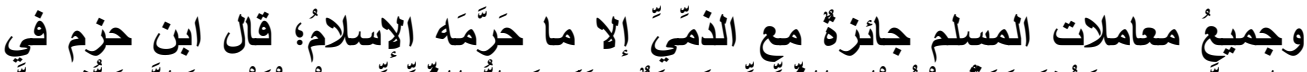

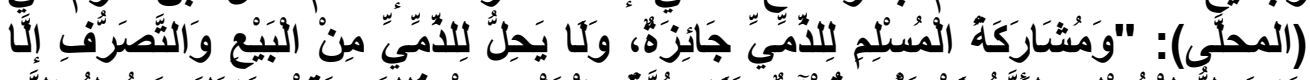

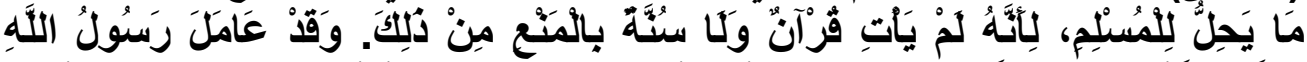

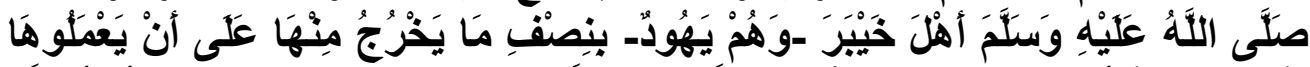

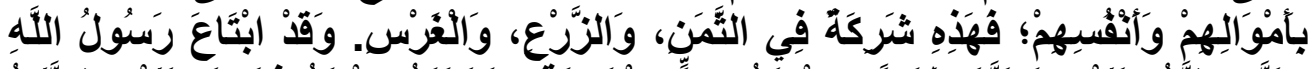

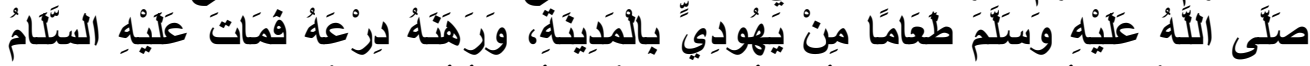

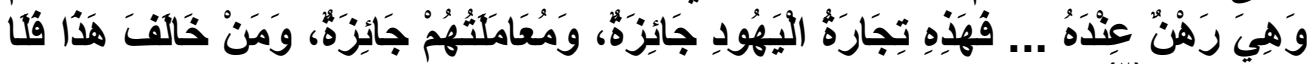

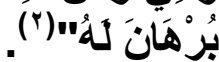

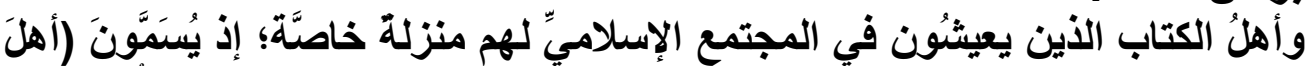

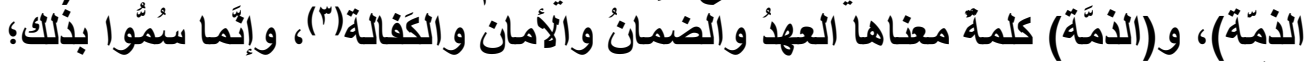

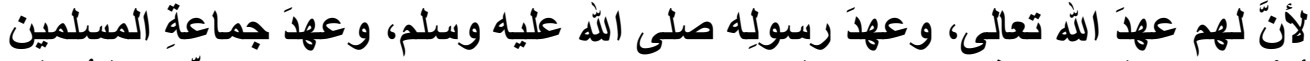

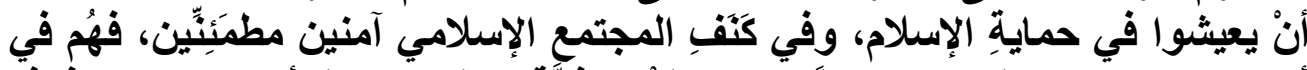

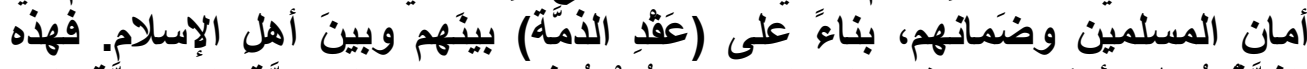

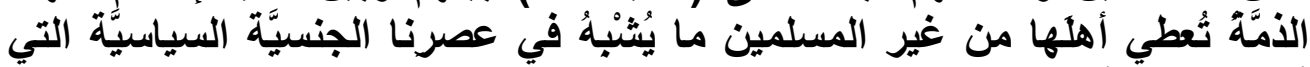

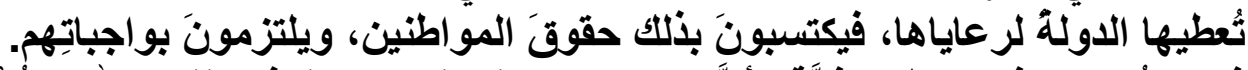

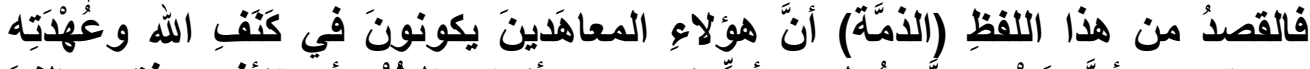

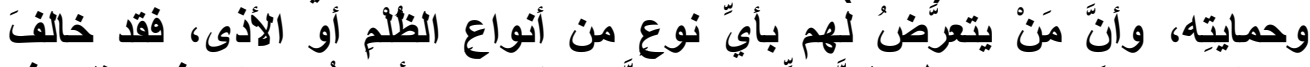

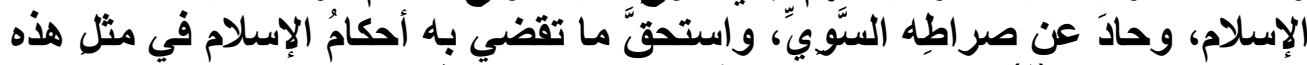

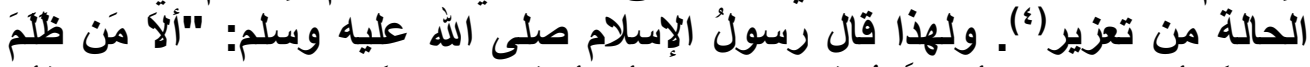

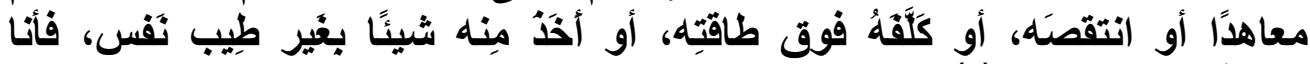

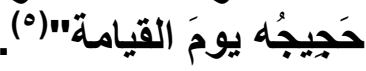

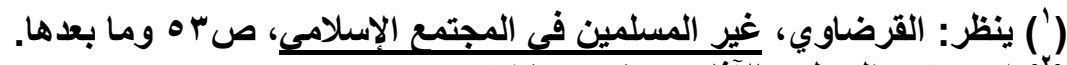

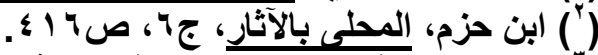

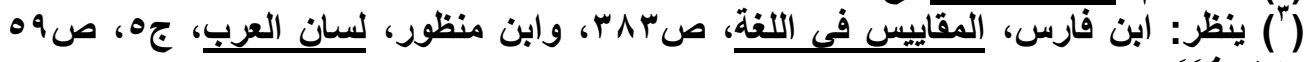

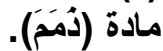

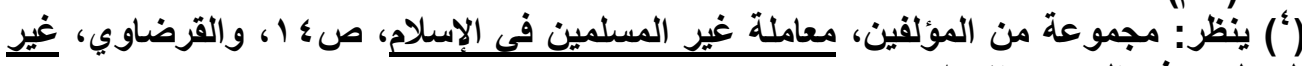

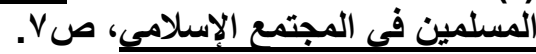

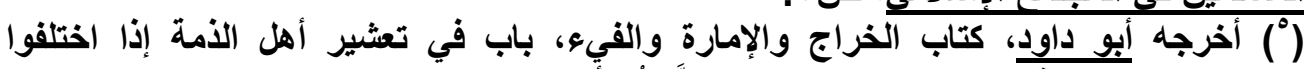

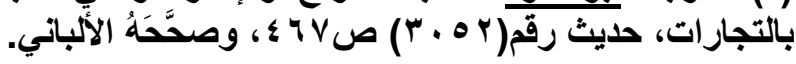




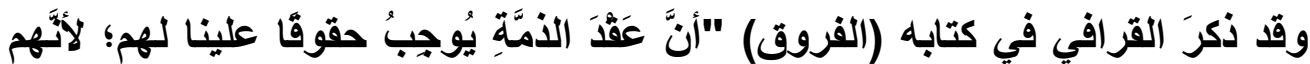

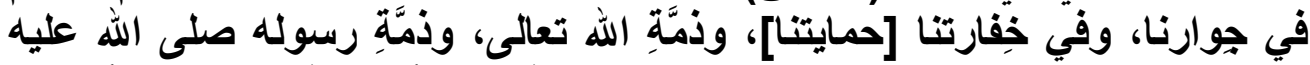

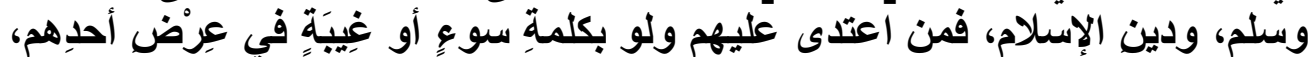

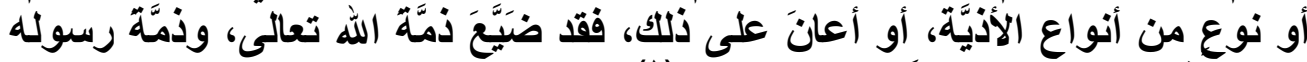

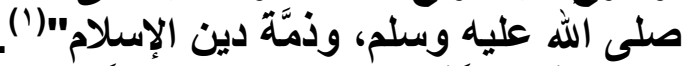

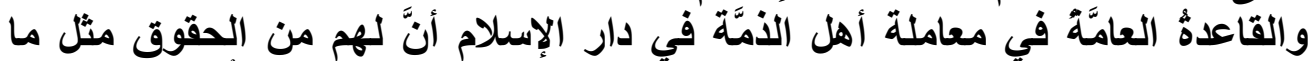

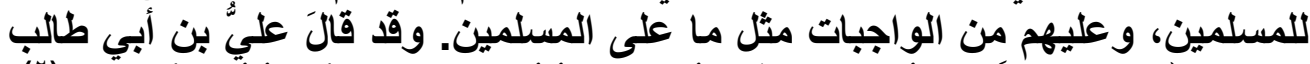

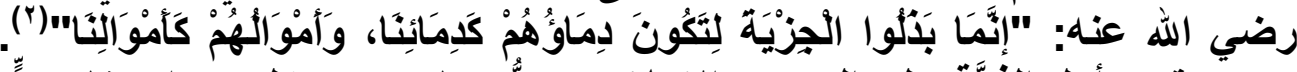

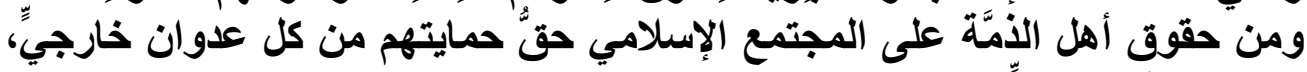
ومن كل ظلم دمن داخلي.

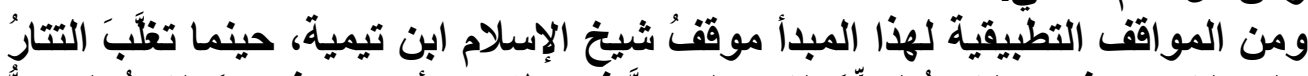

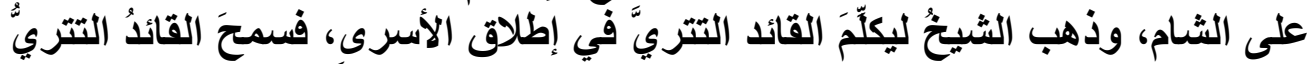

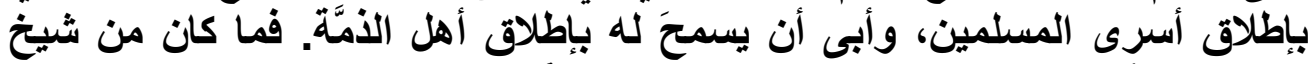

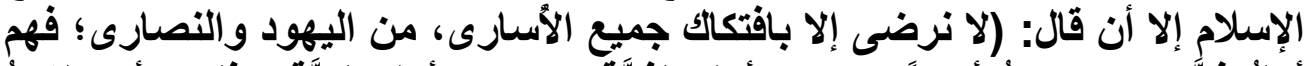

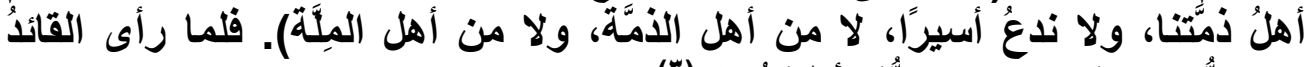

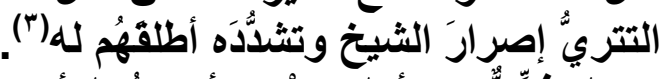

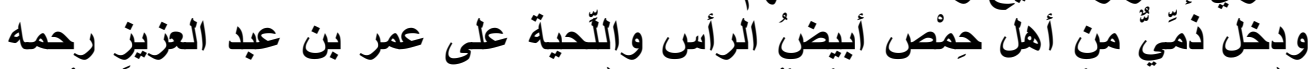

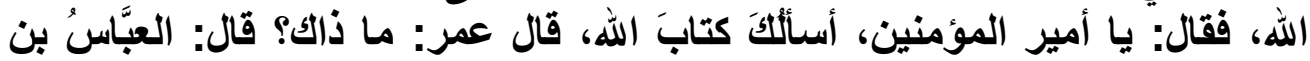

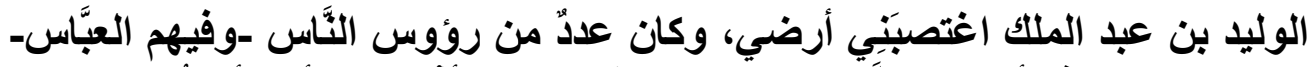

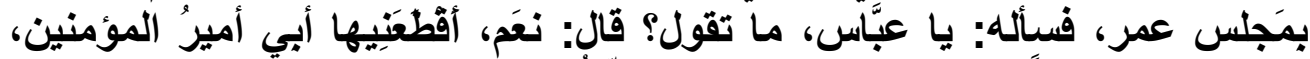

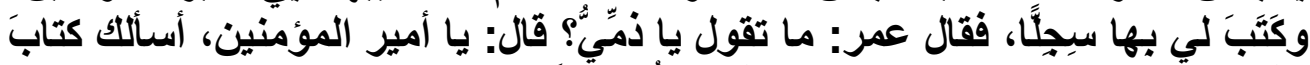

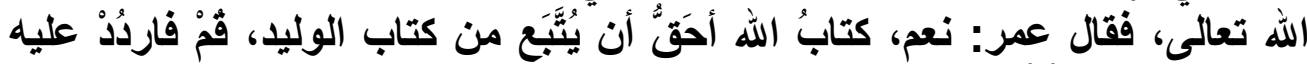

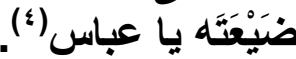

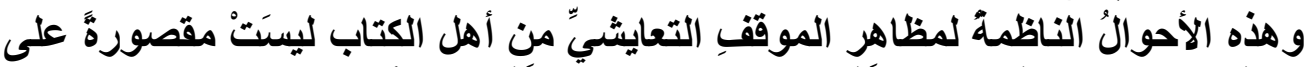

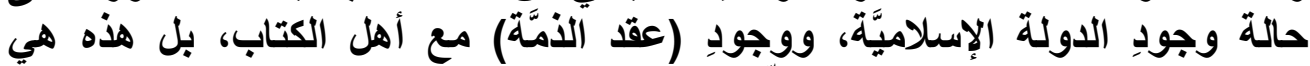

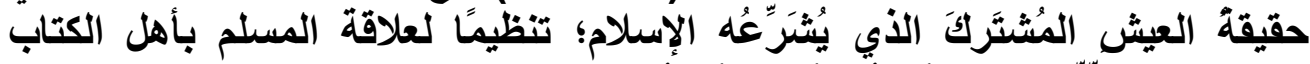

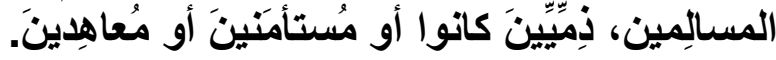

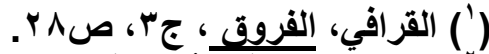

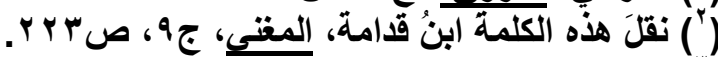

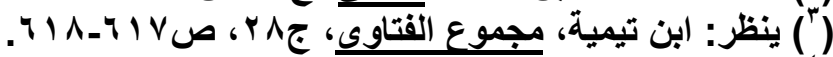

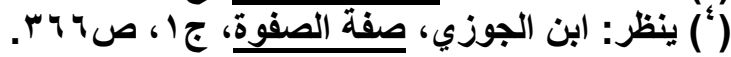




\section{المطلب الثاني}

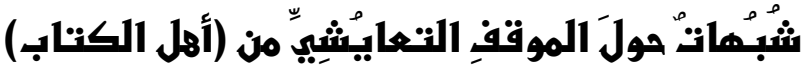

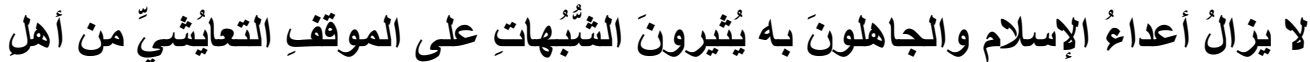

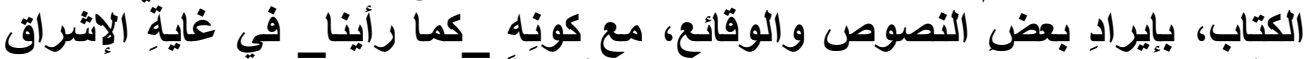

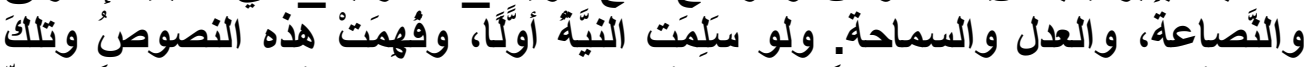

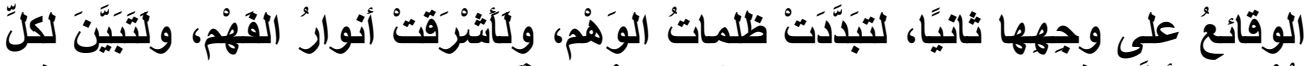

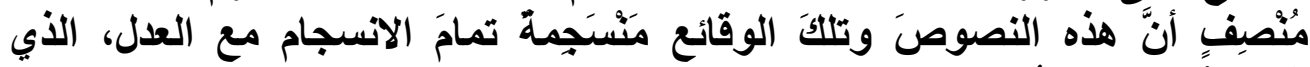

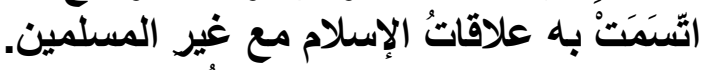

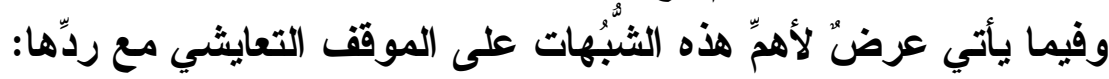

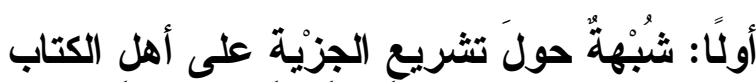

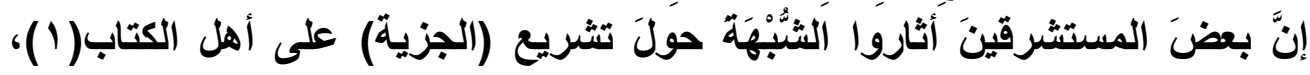

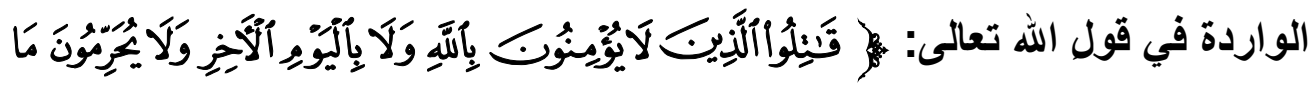

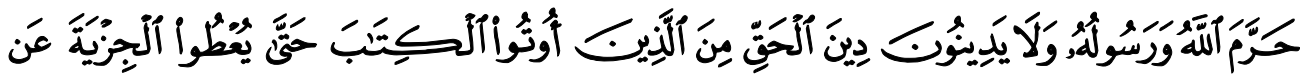

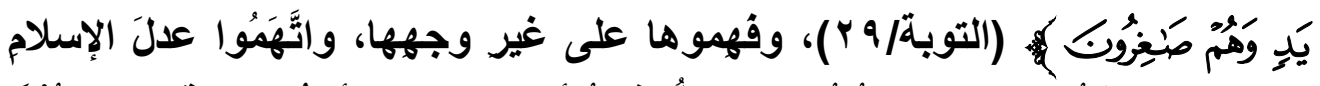

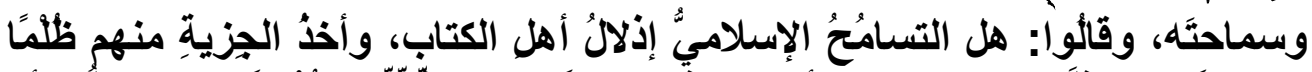

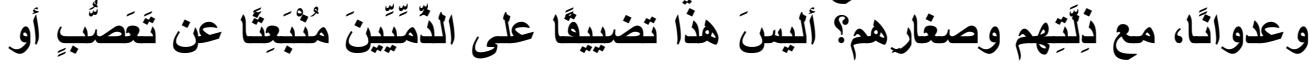
بغضاء؟

ردذُ هذه الثنبُهة:

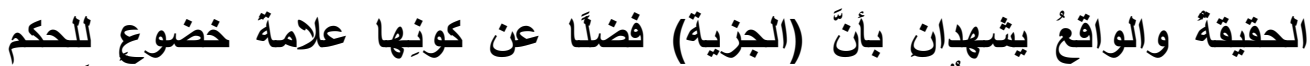

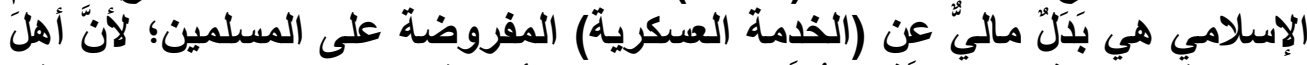

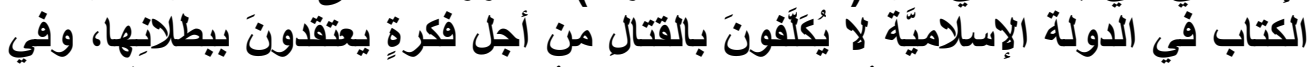

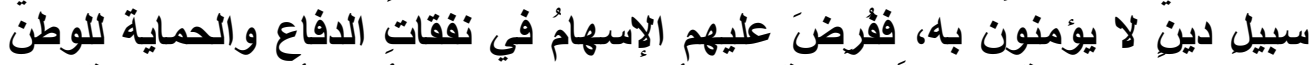

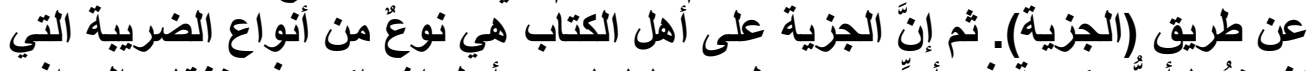

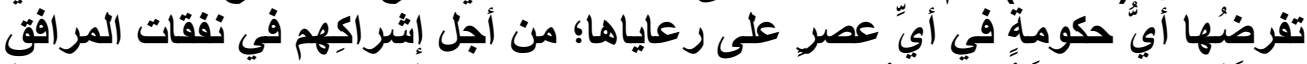

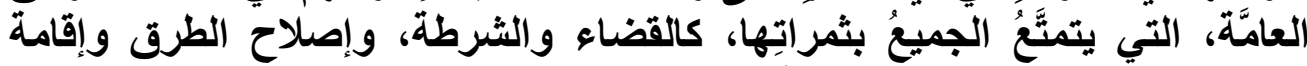

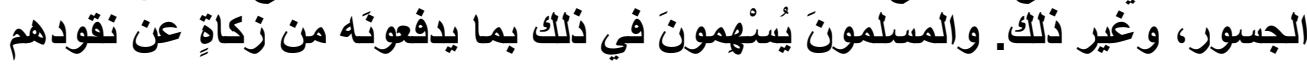

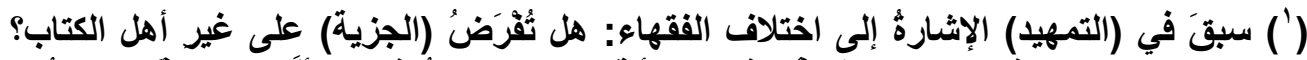

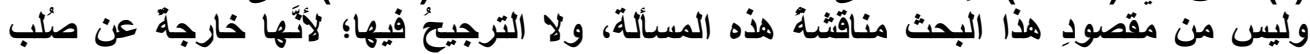
موضو عه، وهو الديثُ عن أهل الكتاب خصوصنًا. 


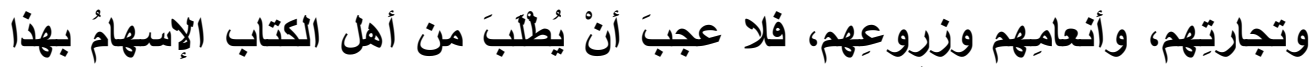

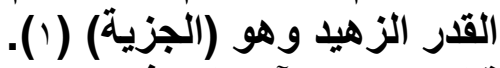

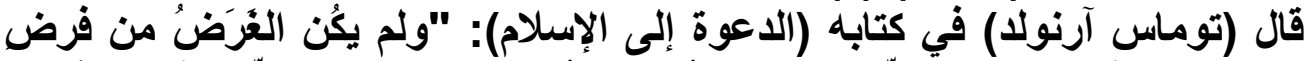

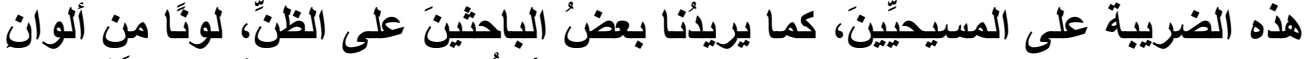

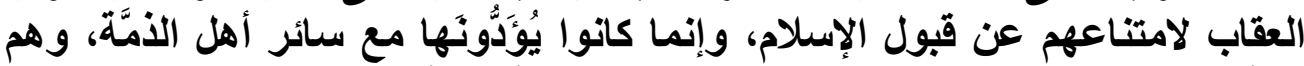

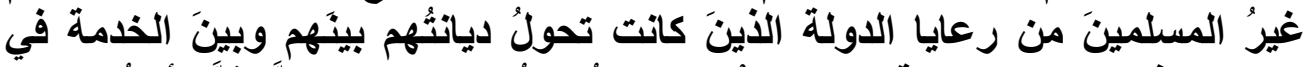

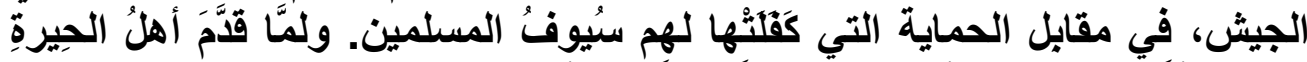

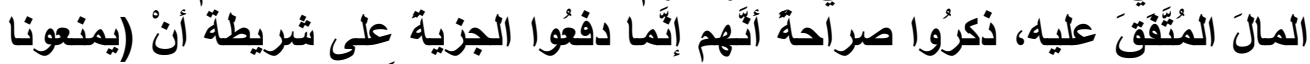

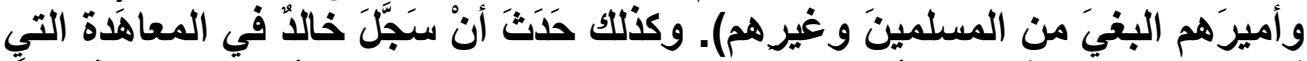

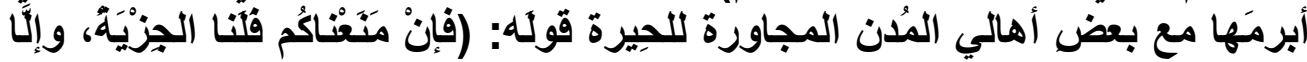

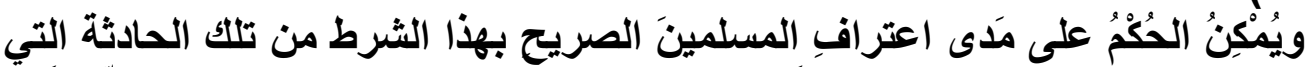

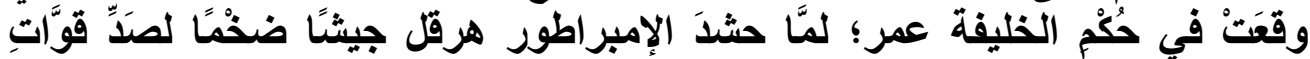

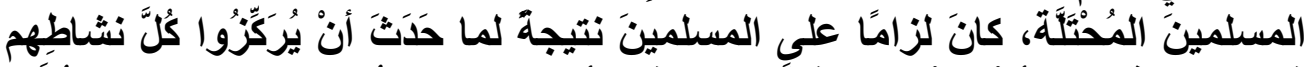

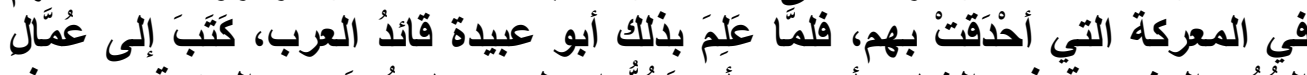

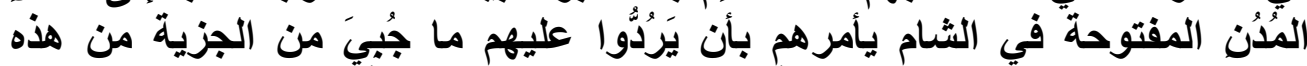

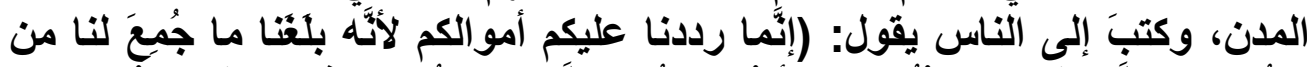

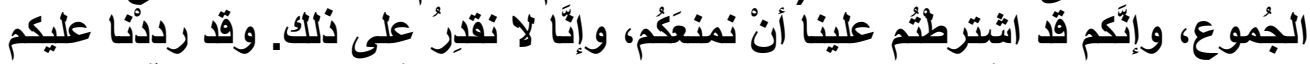

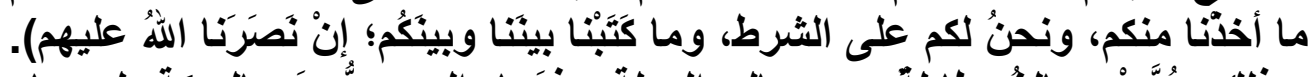

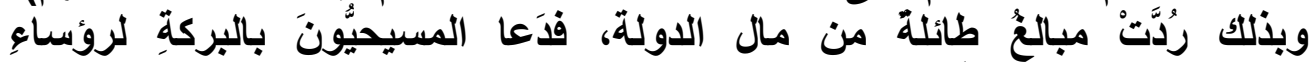

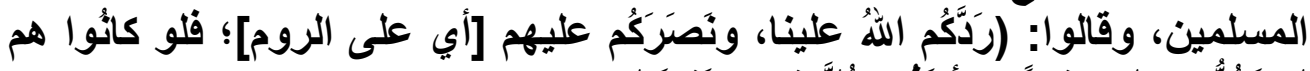

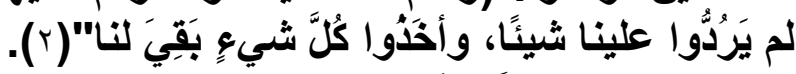

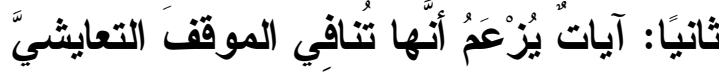

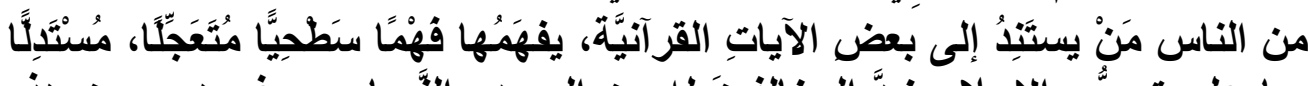

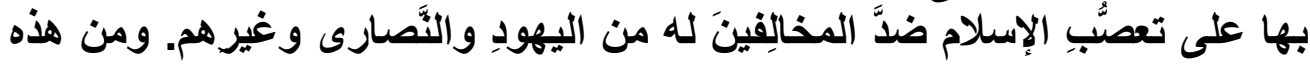

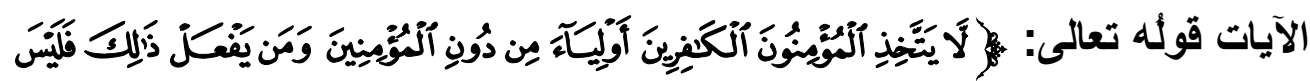

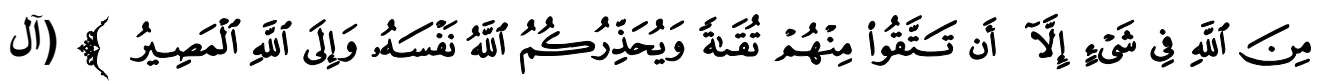

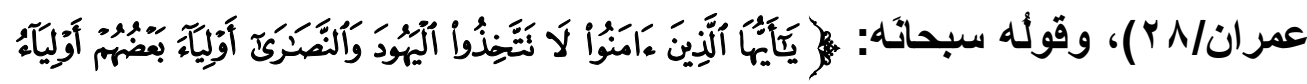

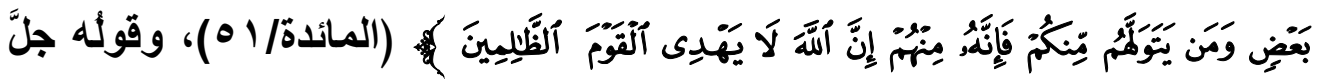

$$
\begin{aligned}
& \text { (') ينظر: القرضاوي، غير المسلمين في المجتمع الإسلامى، صهوبَ وما بعدها. }
\end{aligned}
$$

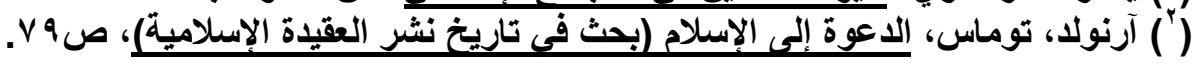




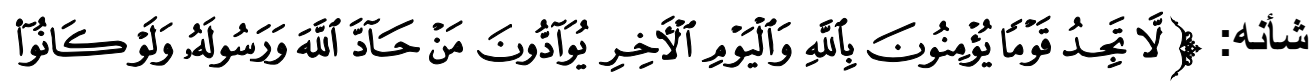

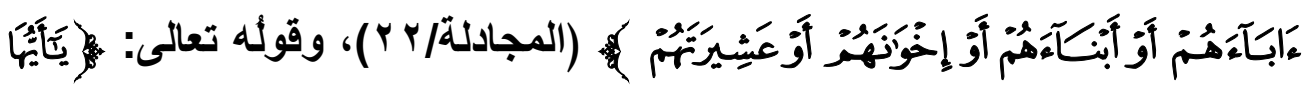

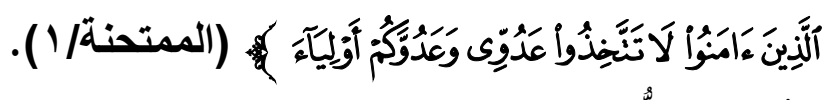

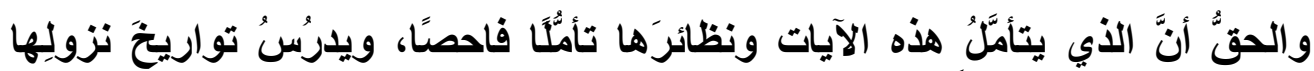

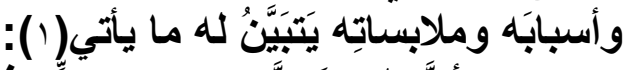

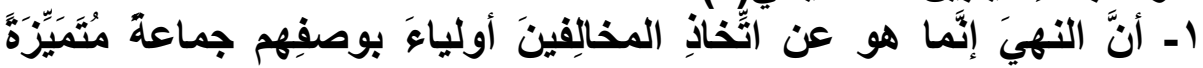

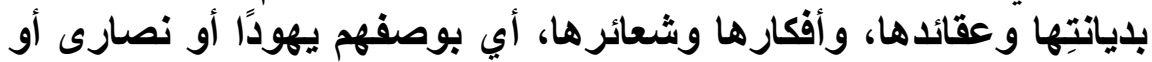

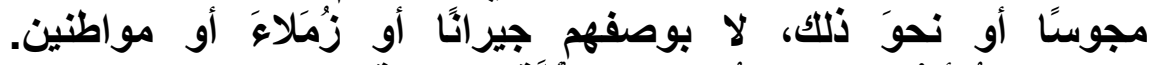

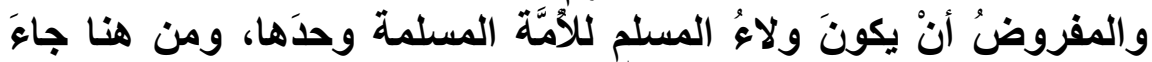

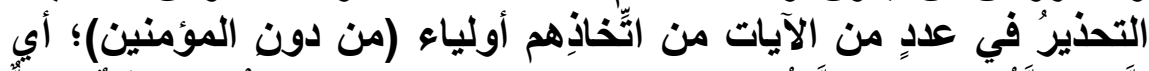

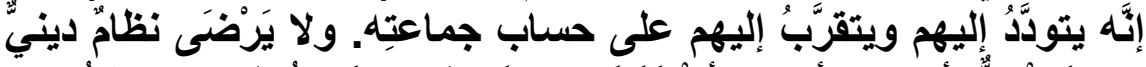

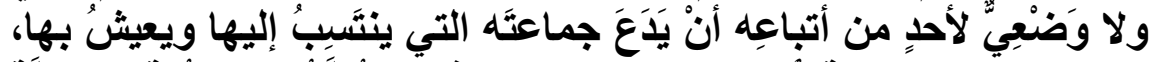

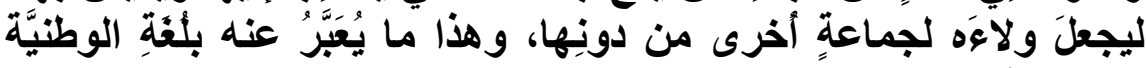

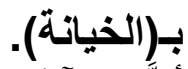

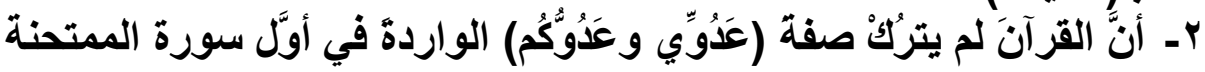

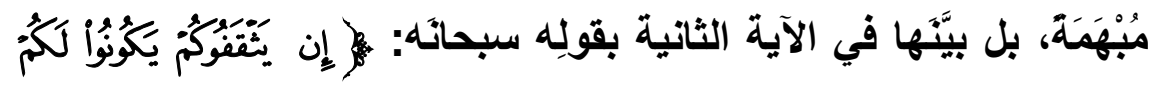

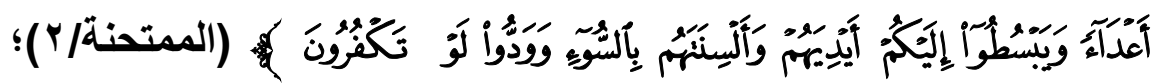

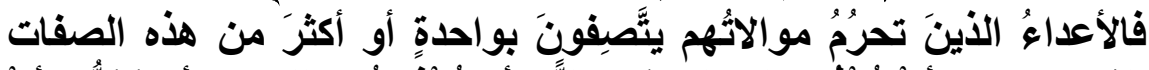

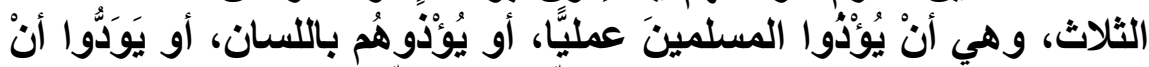

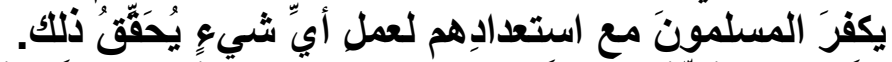

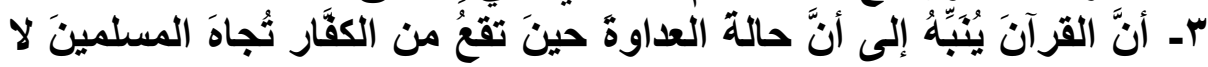

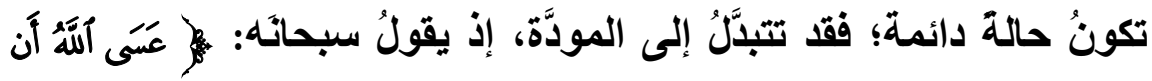

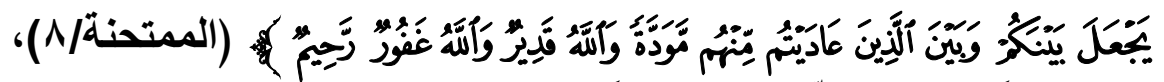

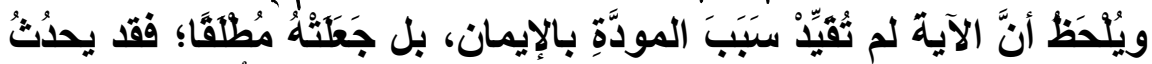

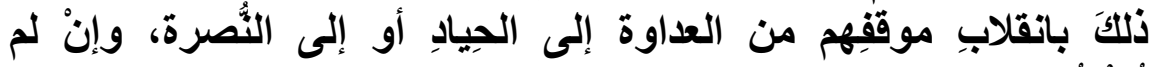

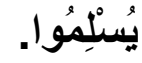

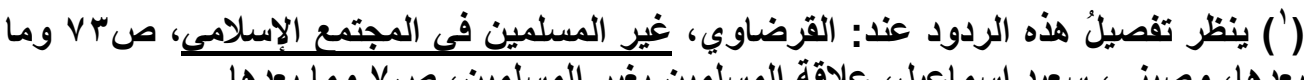

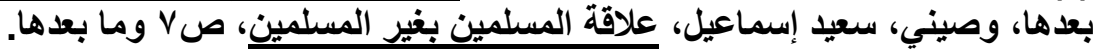




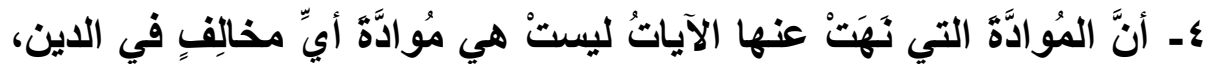

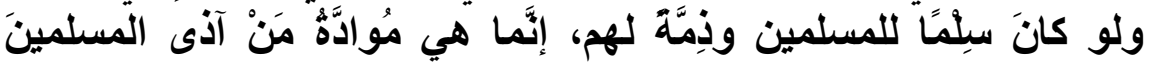

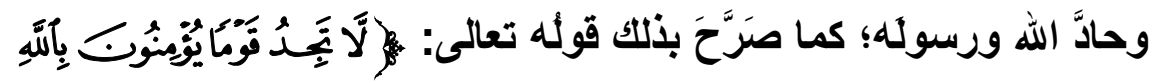

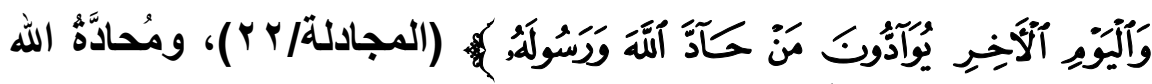

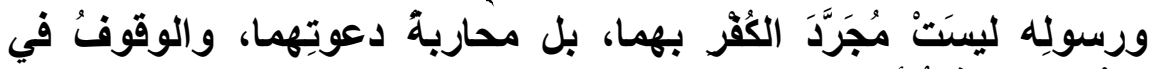

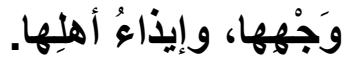

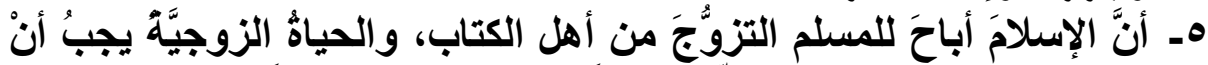

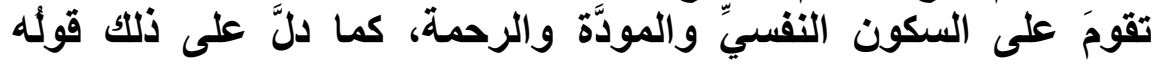

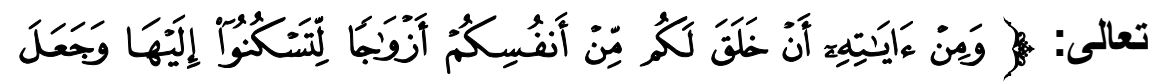

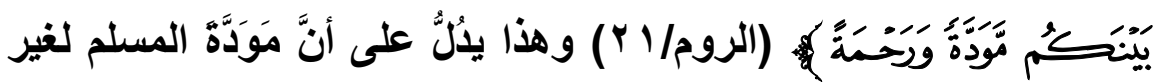

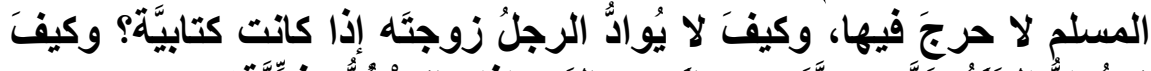

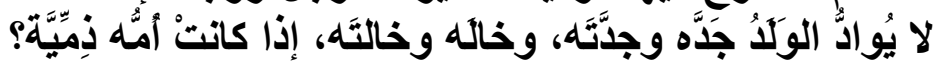

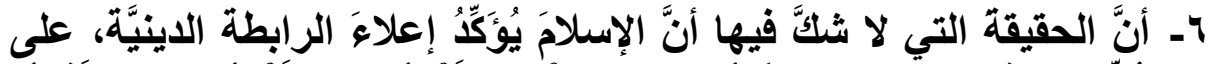

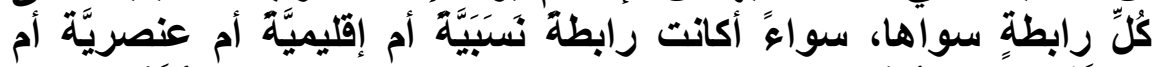

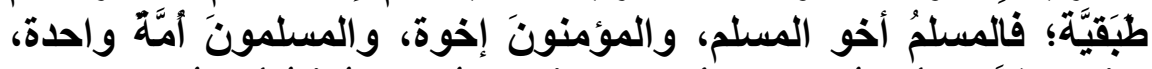

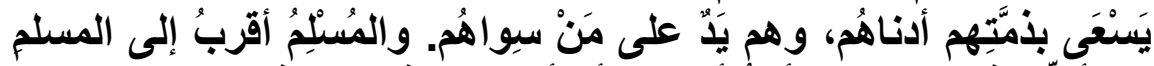

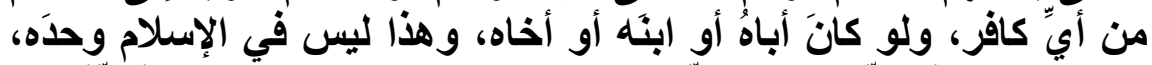

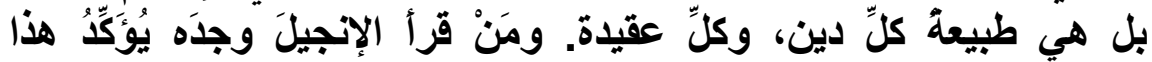
المعنى في أكثرَ من موقنف دين. 


\section{المبمث الثالث

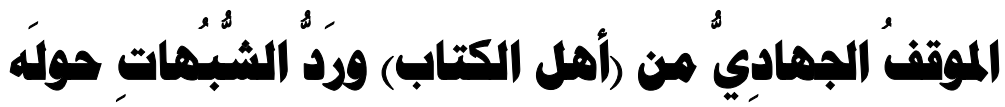 \\ المطلب الأول}

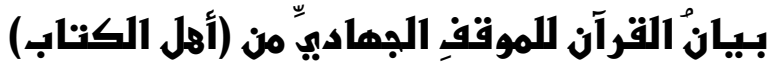

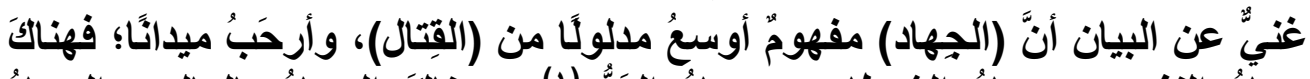

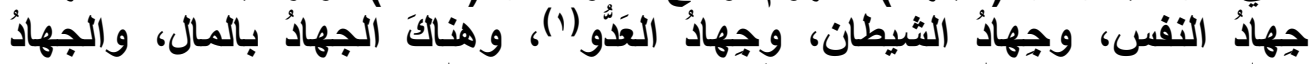

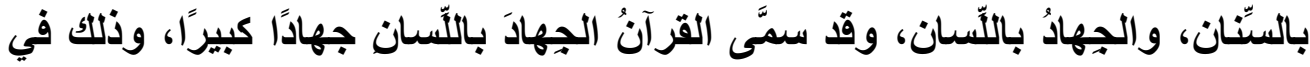

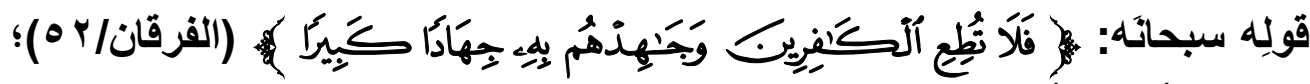

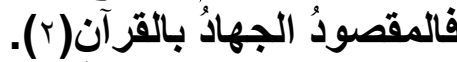

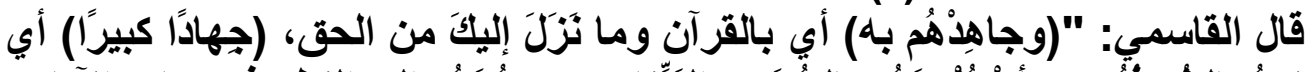

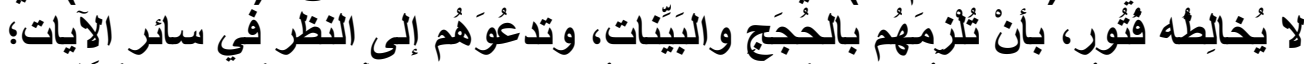

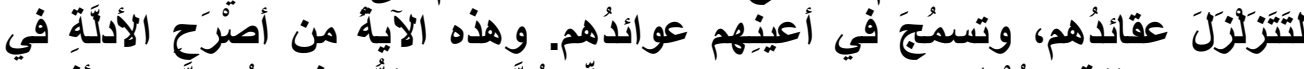

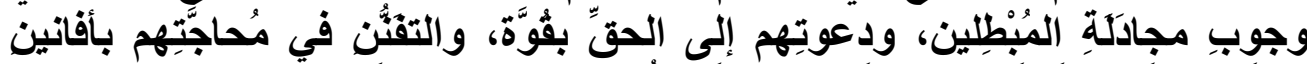

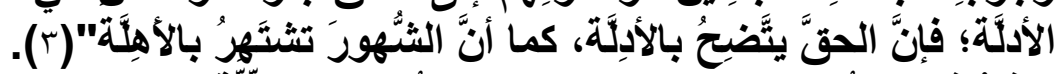

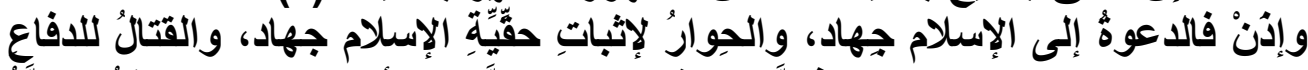

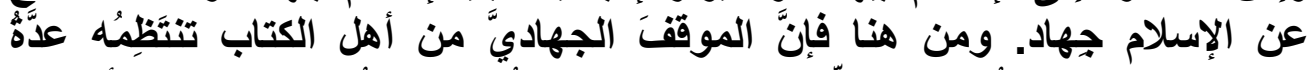

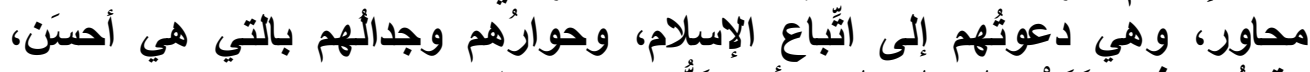

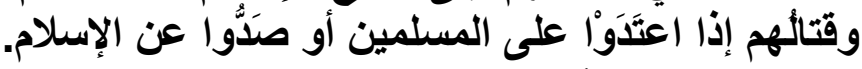

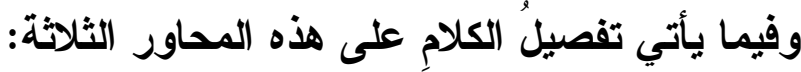

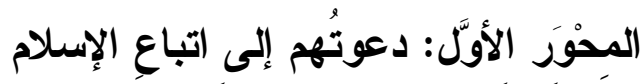

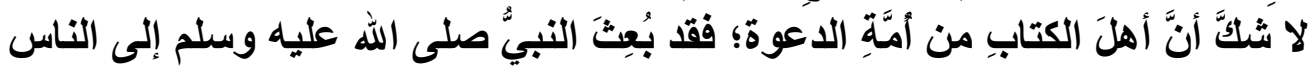

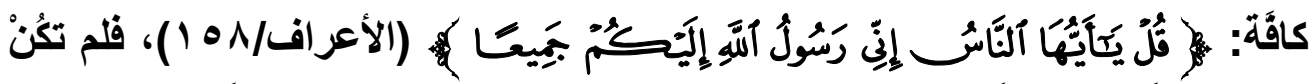

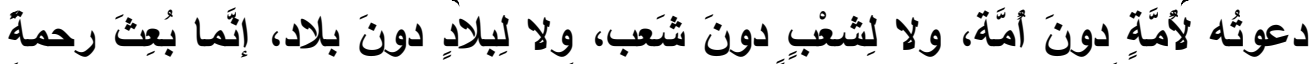

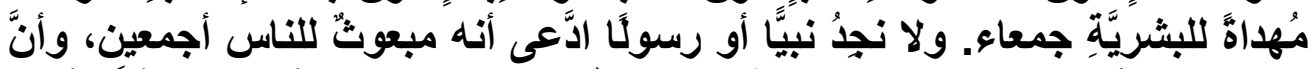

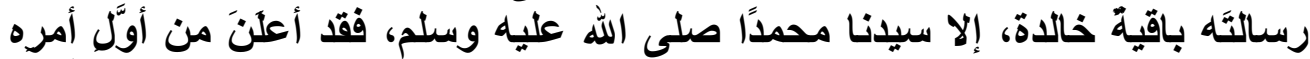

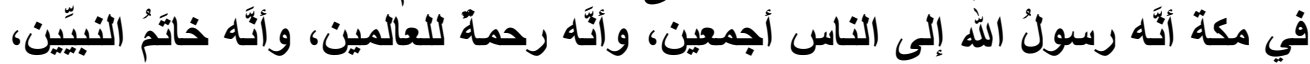

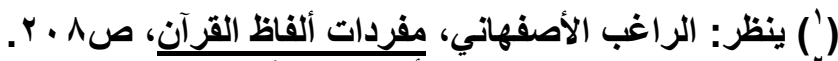

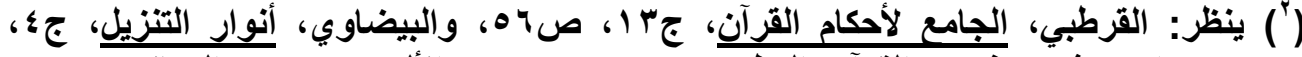

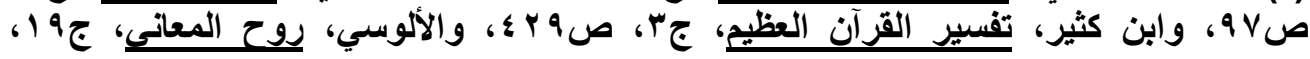
(") القاسمي، محاسن التأويل، جV، ص ب ؟ ؛ . 


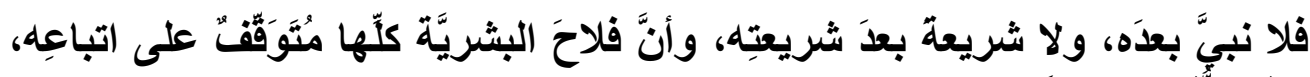

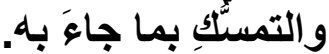

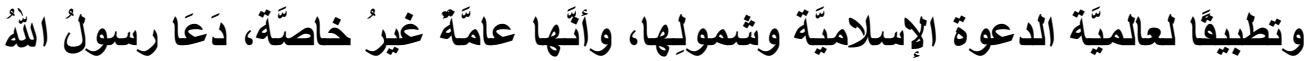

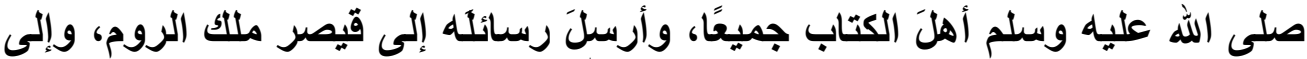

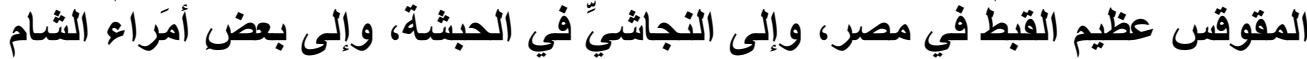

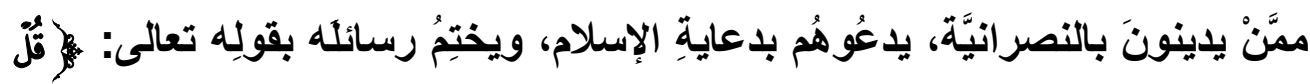

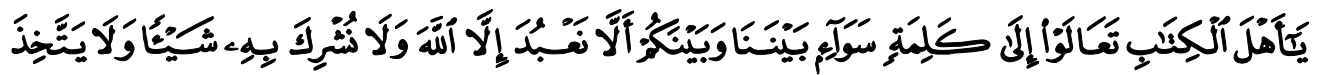

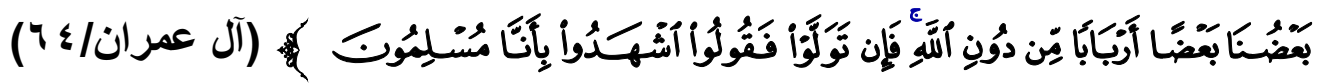

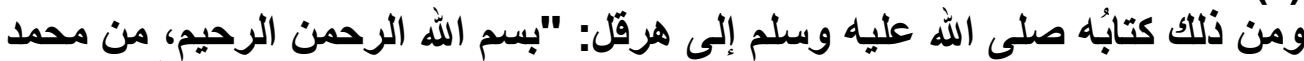

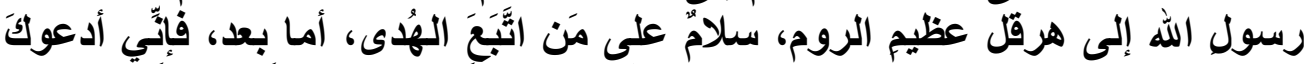

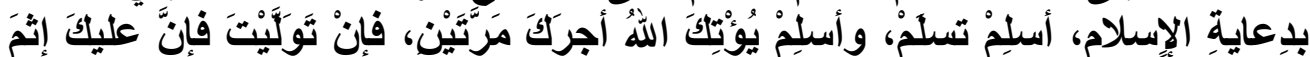

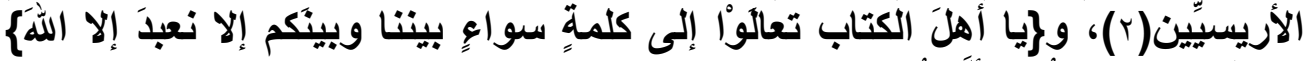

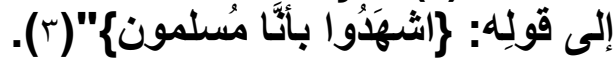

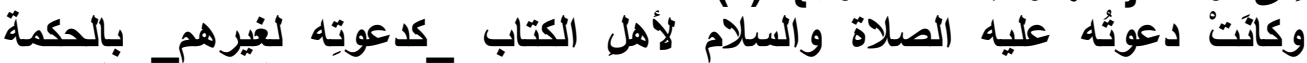

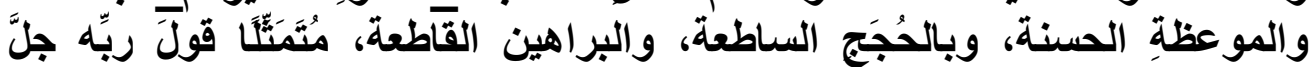

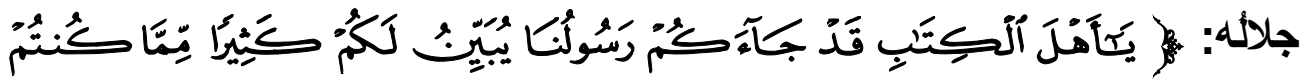

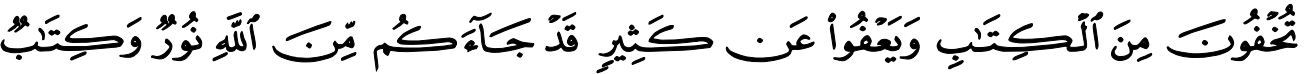

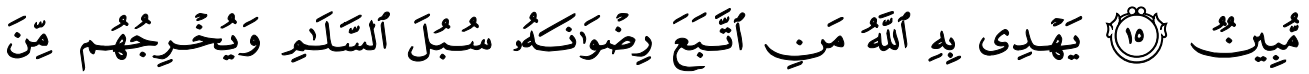

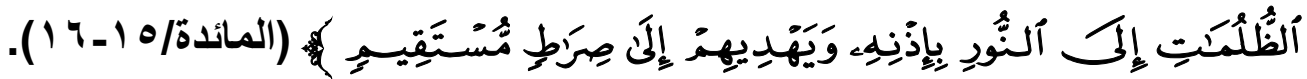
المحْورَ الثاني: حوارُهم وجدألهُم بالتي هي أحسنَ

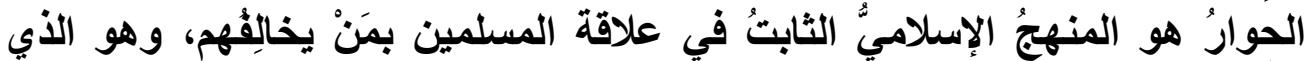

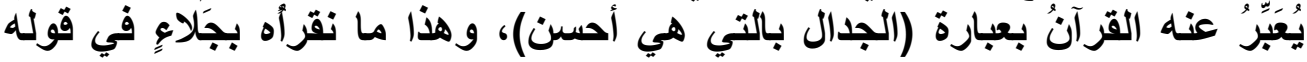

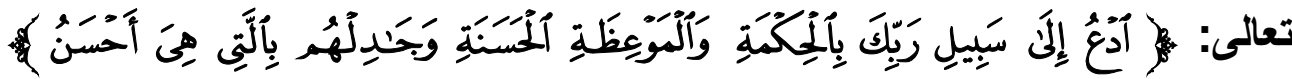

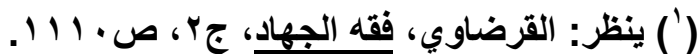

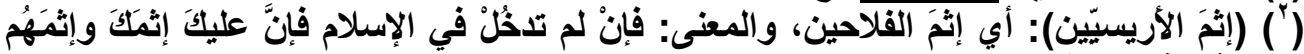

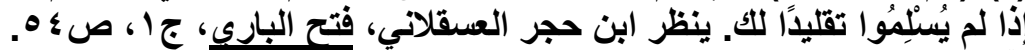

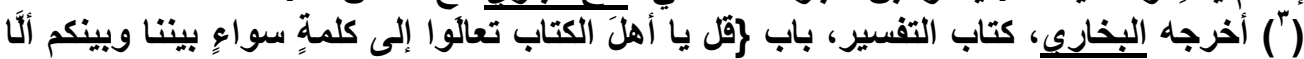

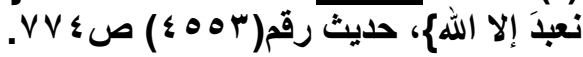




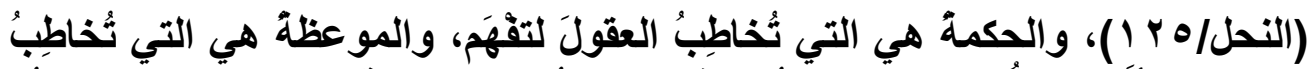

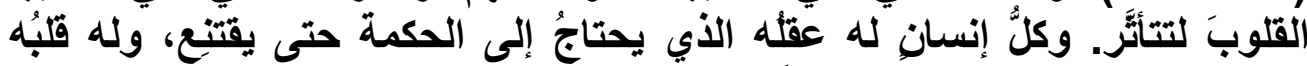

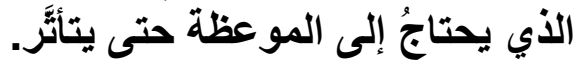

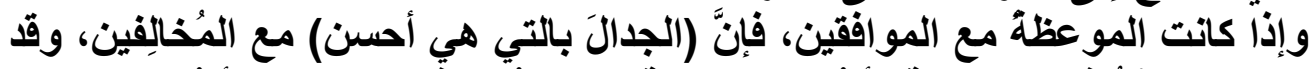

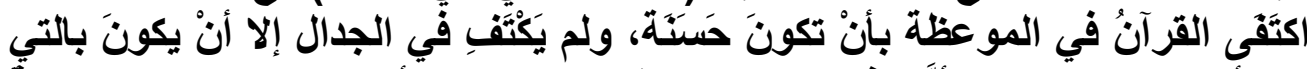

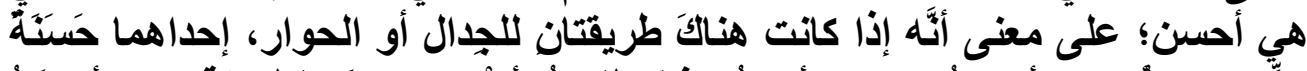

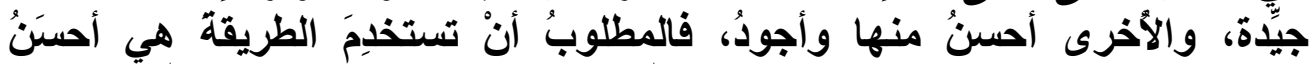

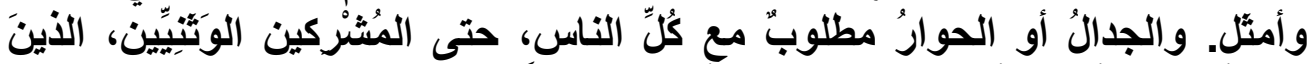

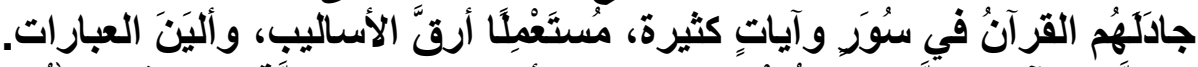

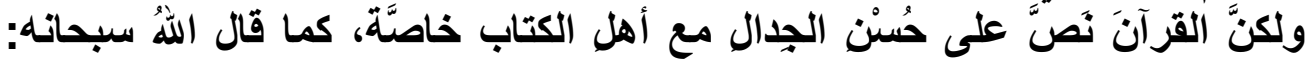

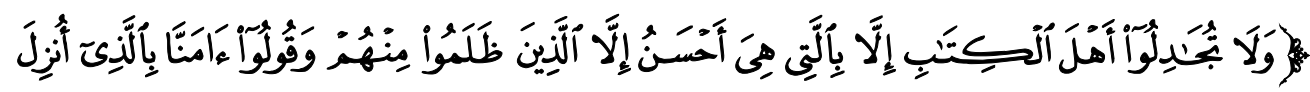

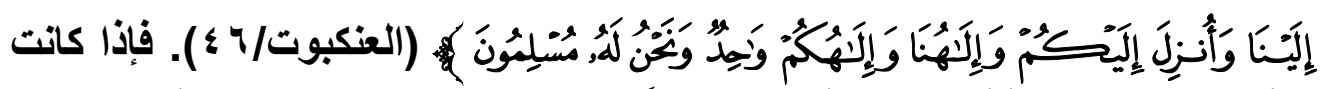

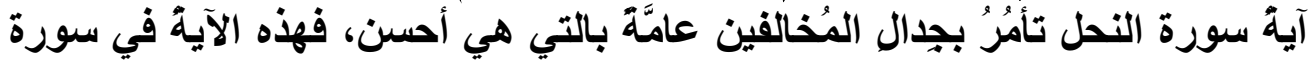

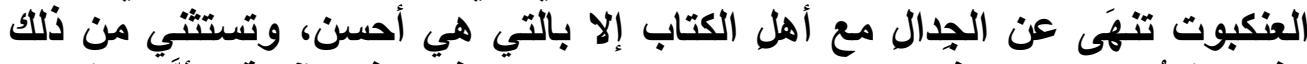

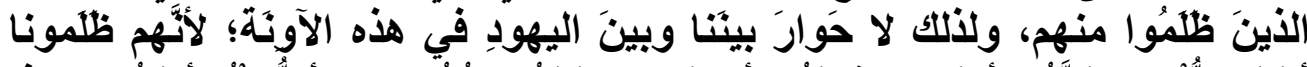

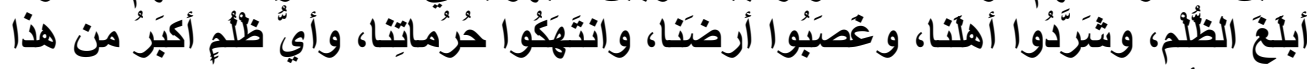

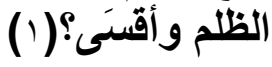

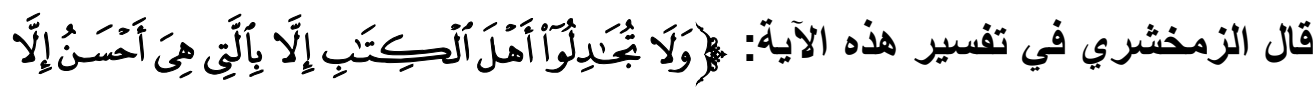

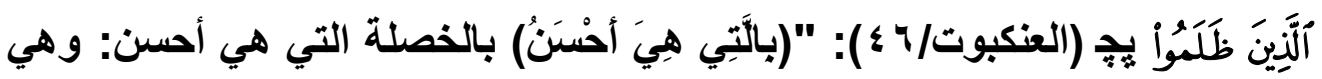

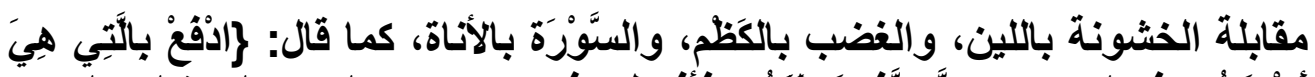

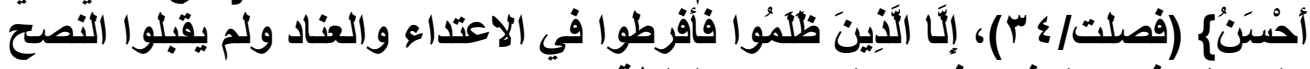
ولم ينفع فيهم الرفقي، فاستعملوا معهم الغلظة") (؟).

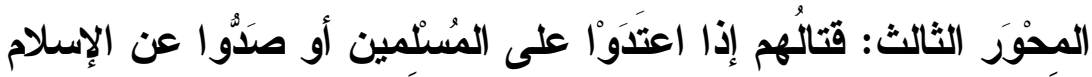

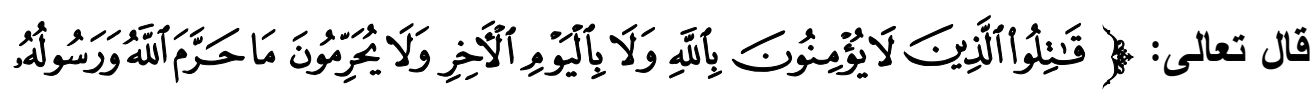

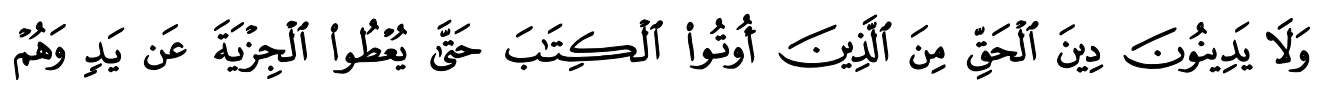

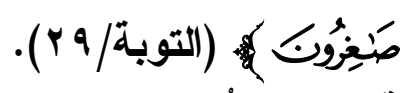

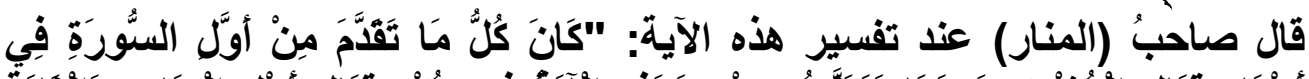

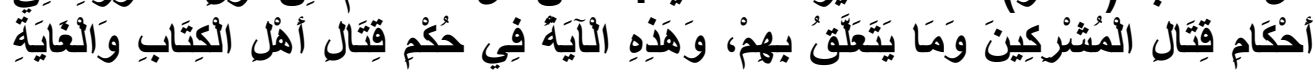

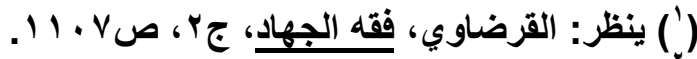

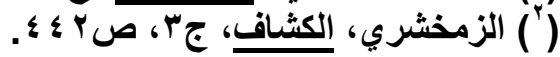




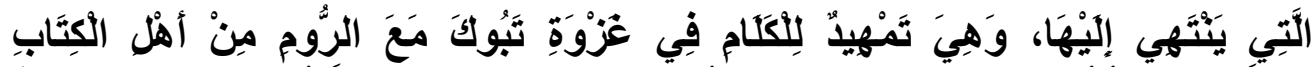

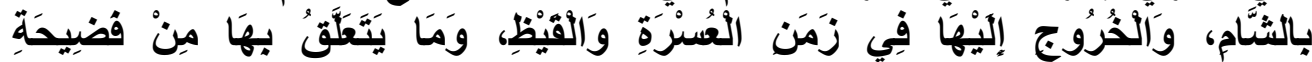

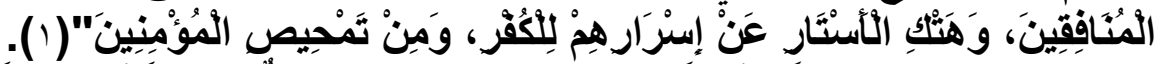

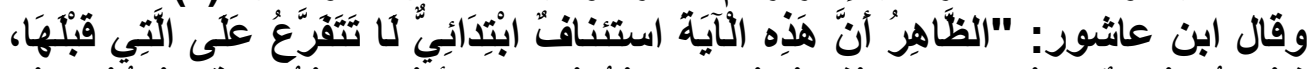

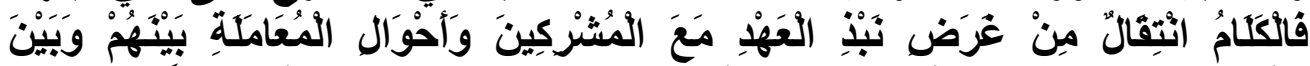

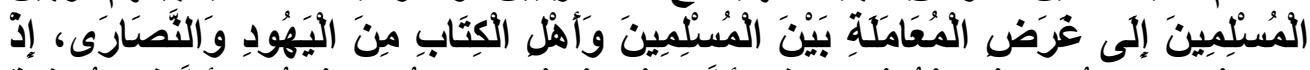

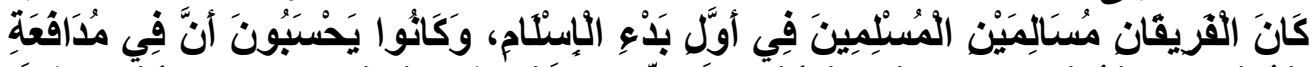

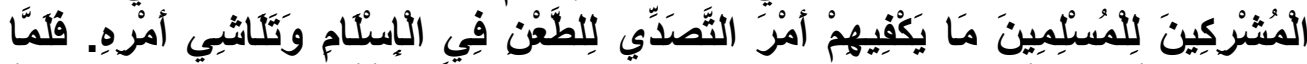

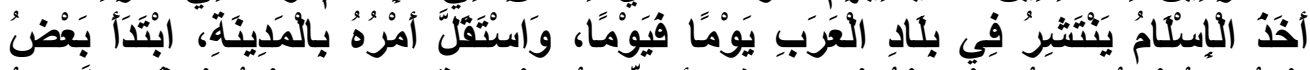

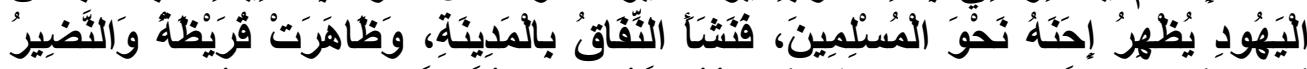

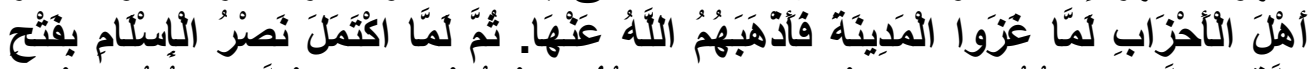

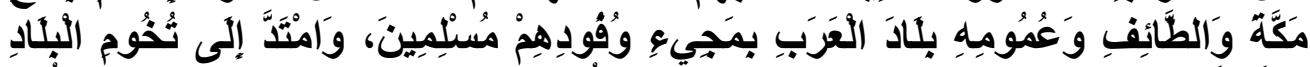

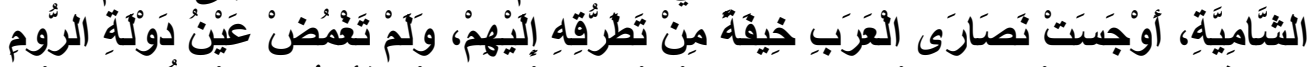

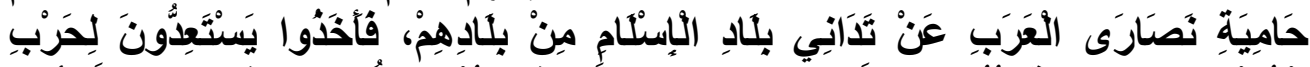

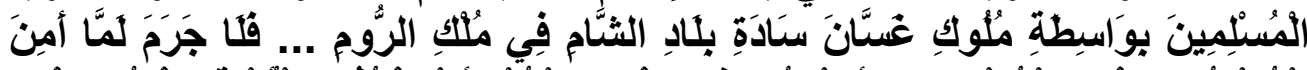

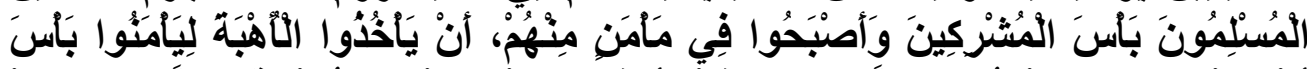

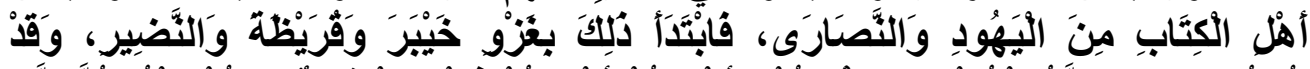

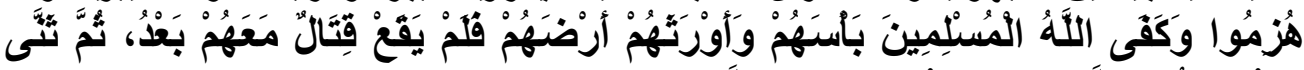

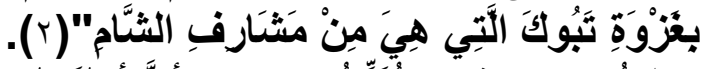

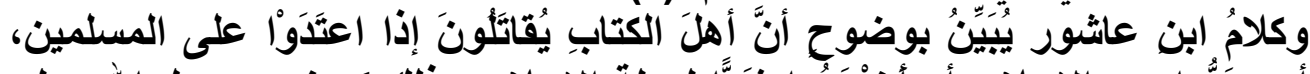

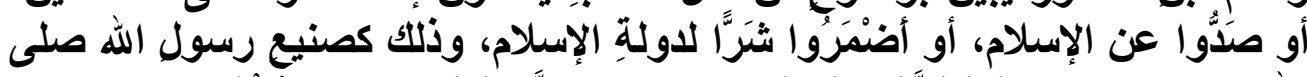

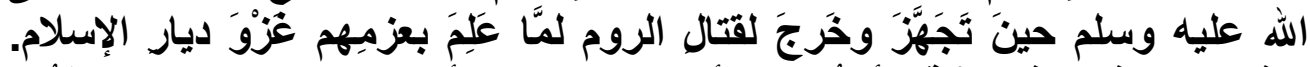

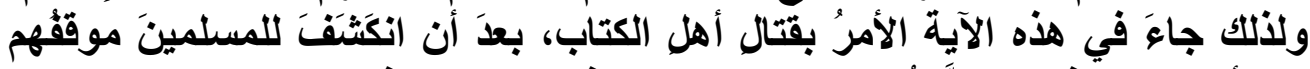

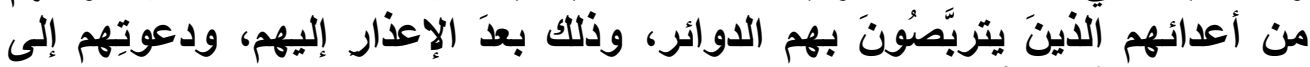

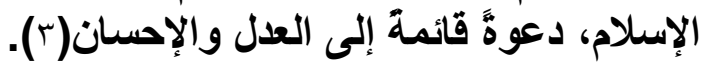

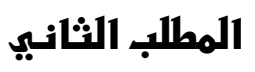

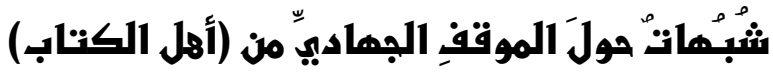

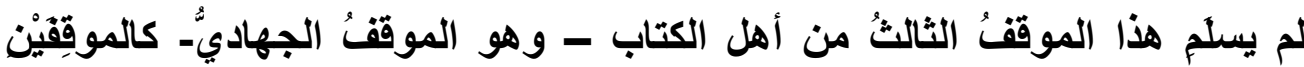

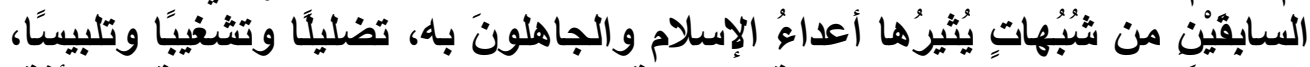

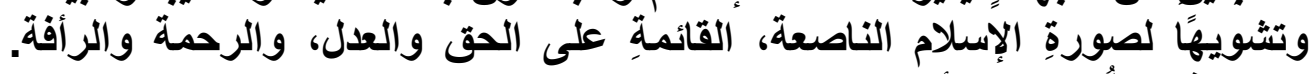

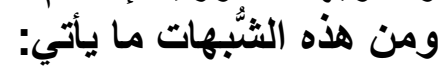

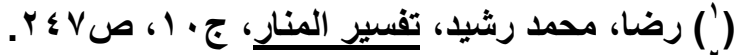

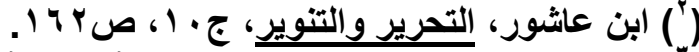

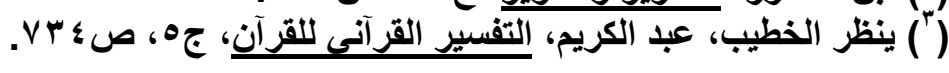


أولًا: زَعْمُ التناقض بينَ نفي الإكراه على الإسلام والأمر بقتال أهل الكتاب.

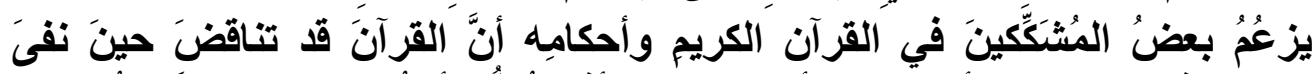

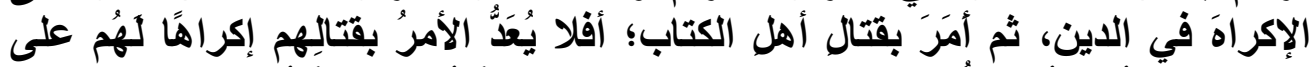

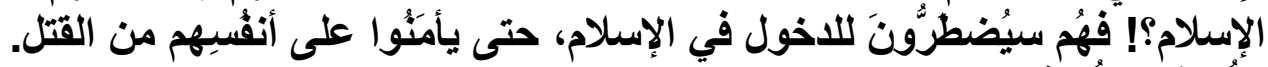

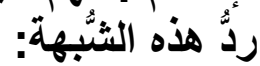

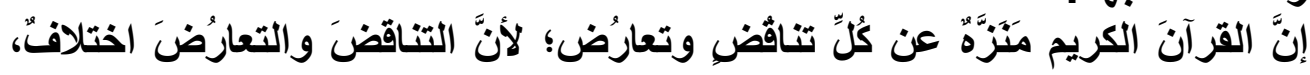

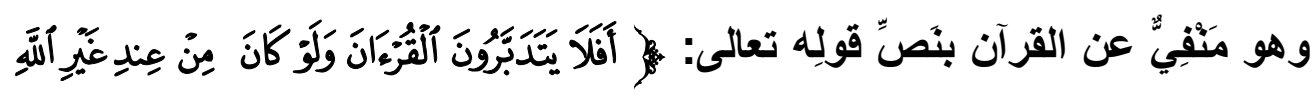

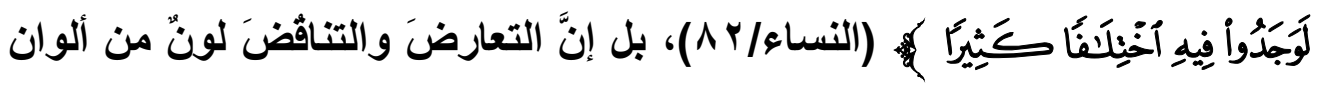

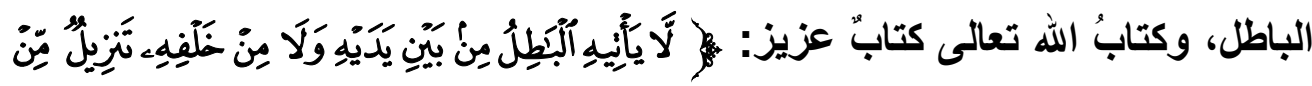

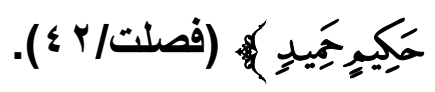

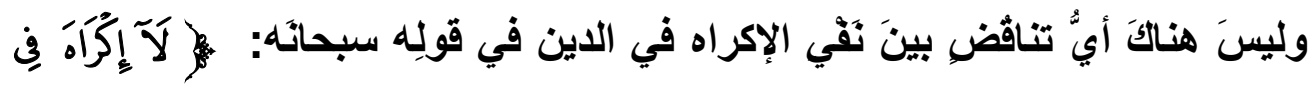

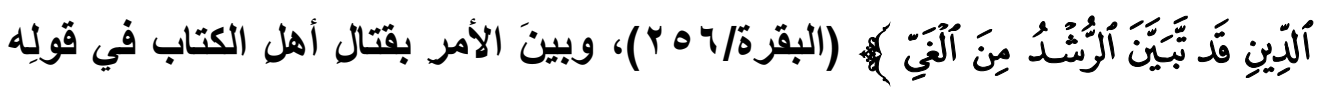

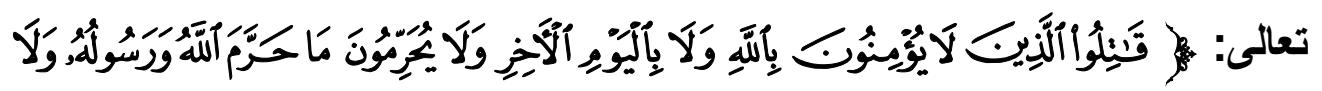

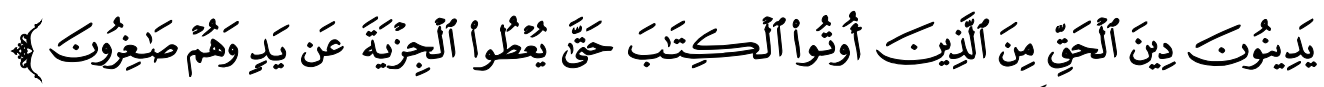

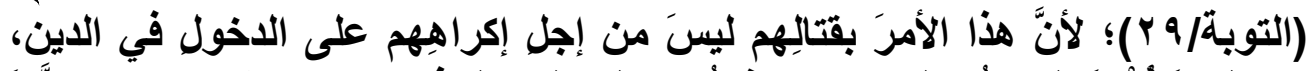

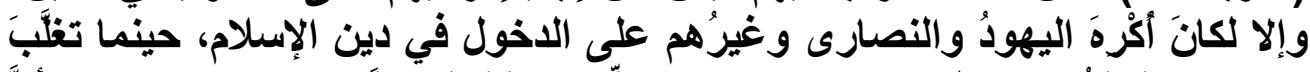

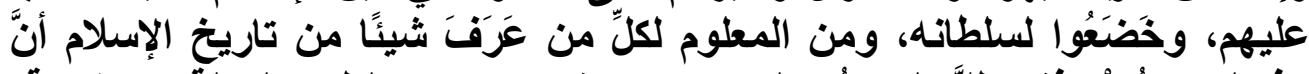

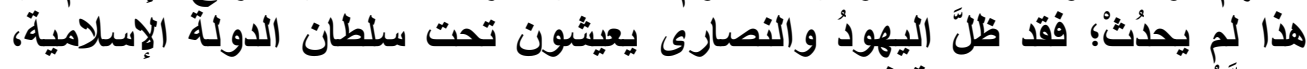
ويتمنَُّون بحريتهم الاينية فئها.

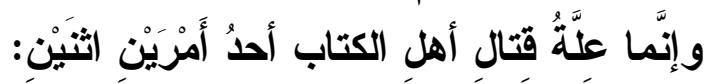

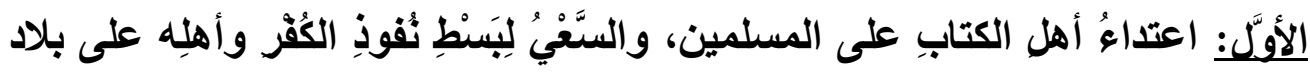

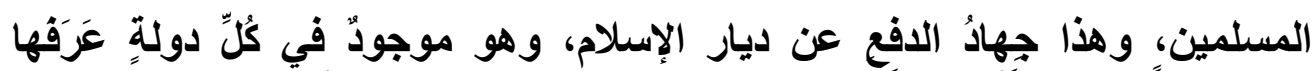

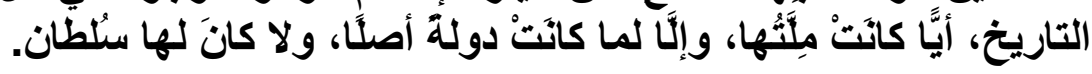

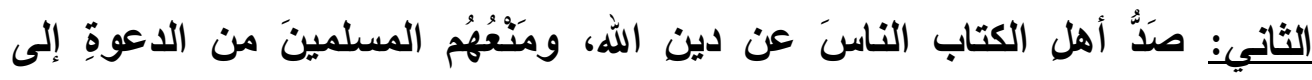

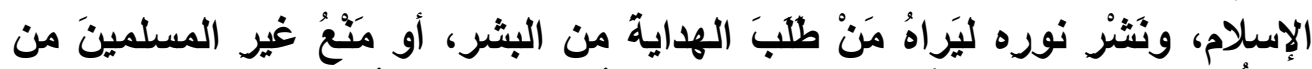

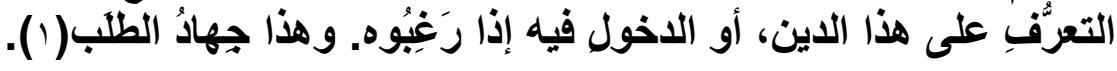

(') ينظر ابن تيمية، السياسة الثرعية، ص..' 


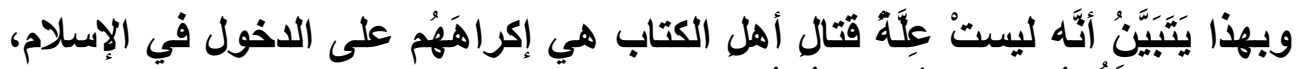

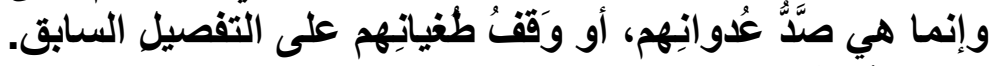

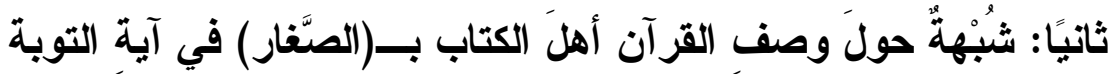

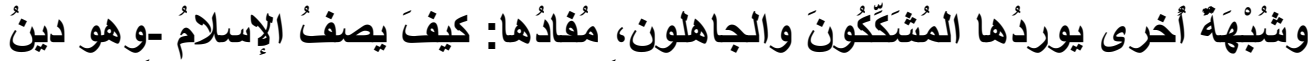

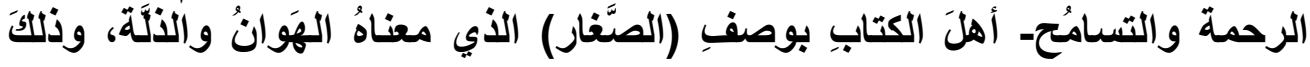

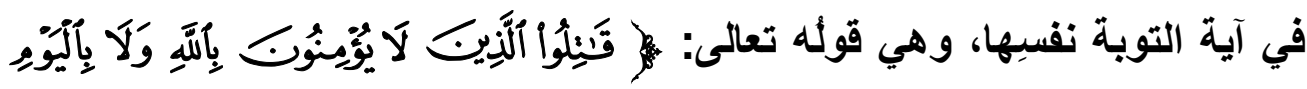

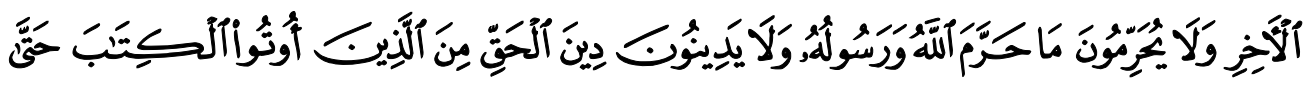

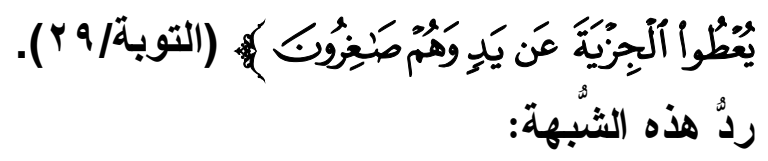

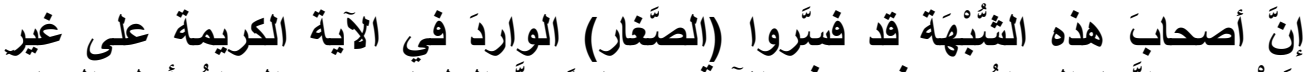

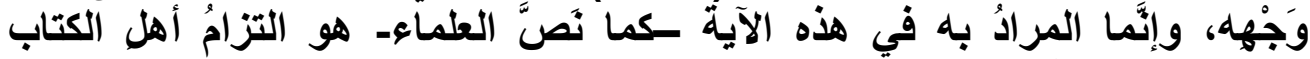

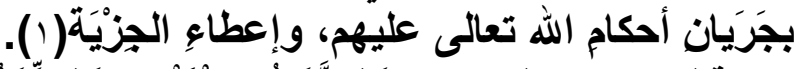

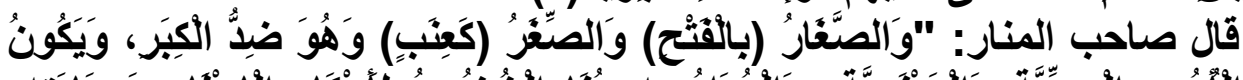

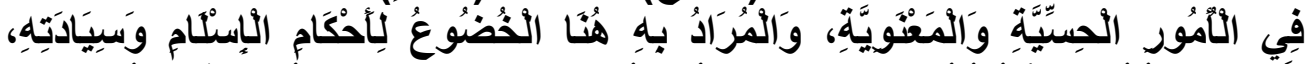

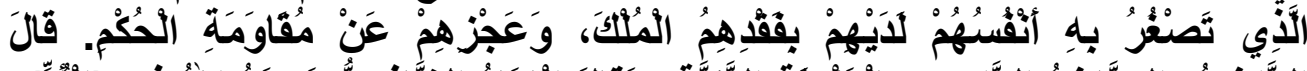

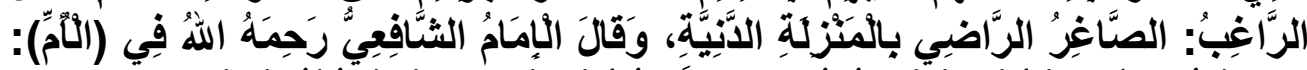

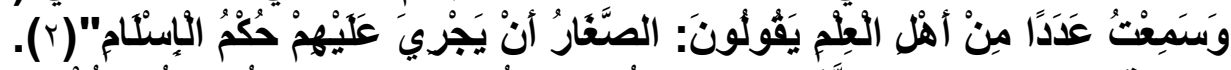

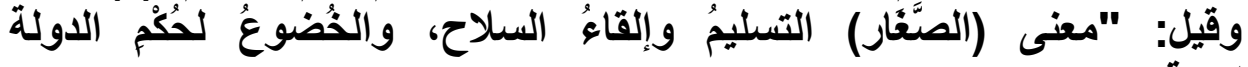

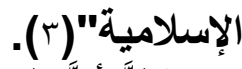

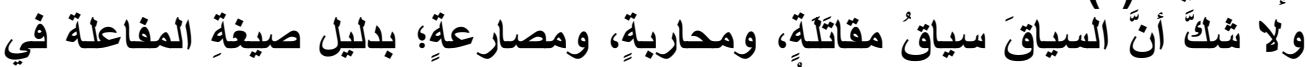

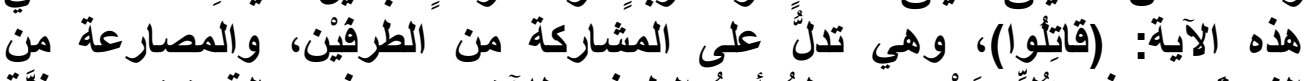

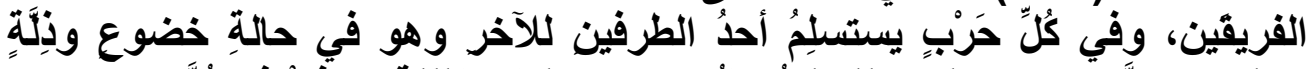

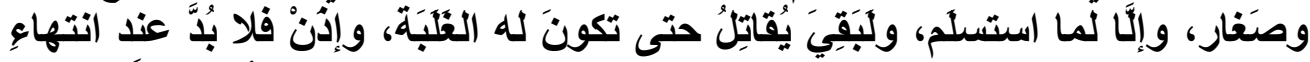

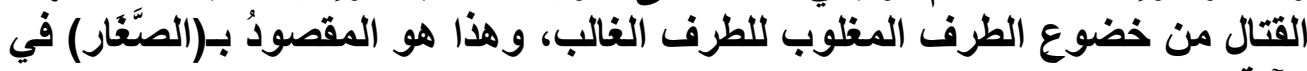
والآية. وبانتهاءِ هذا المبحث ينتهي المقصودُ من هذا البحث، واللهُ وليُّ التوفيق.

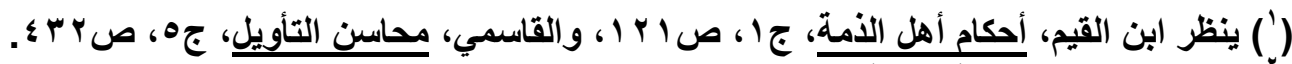

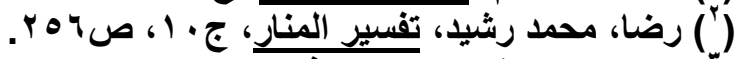

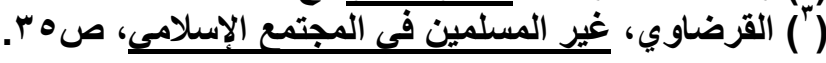




\section{الفاتمة}

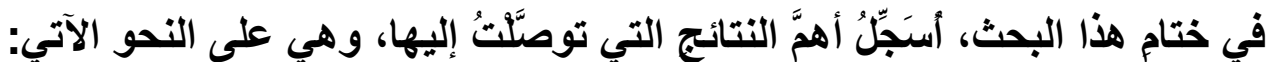

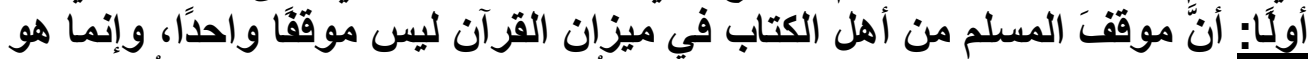

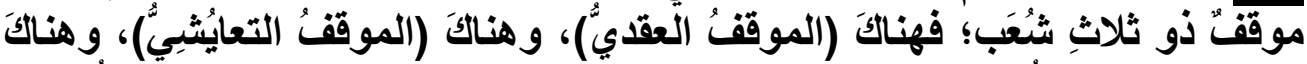

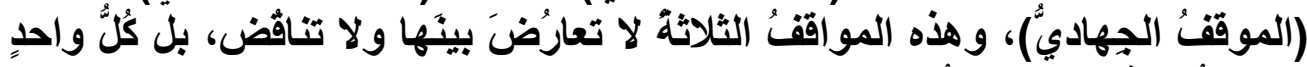

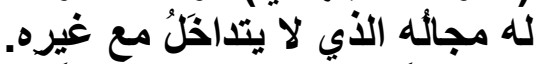

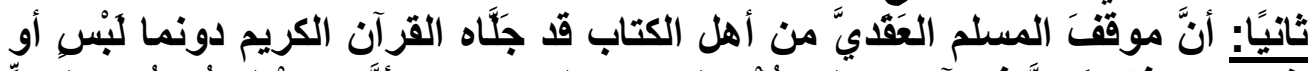

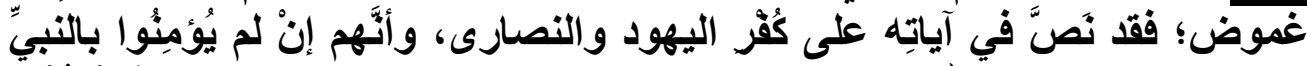

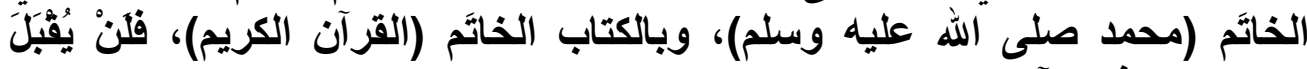

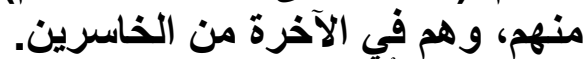

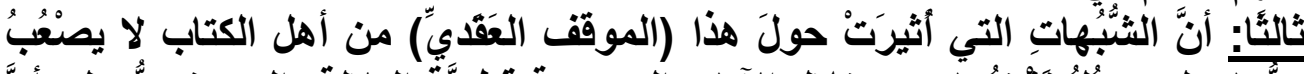

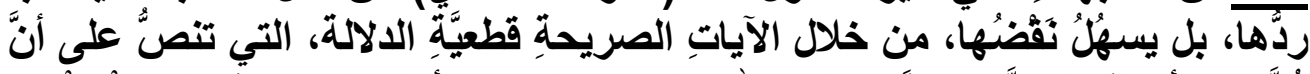

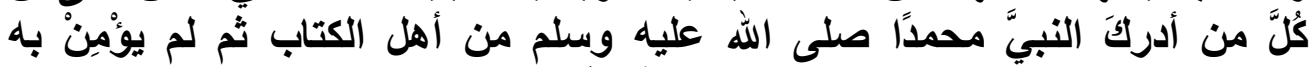

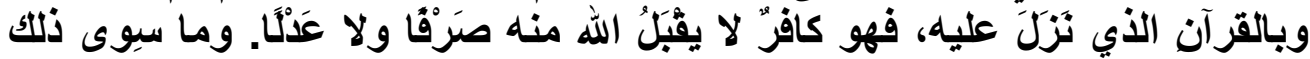

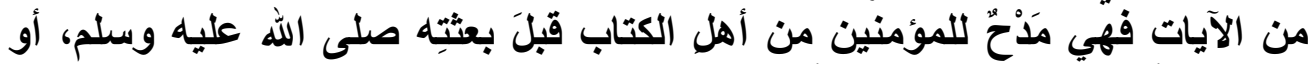

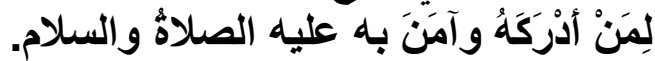

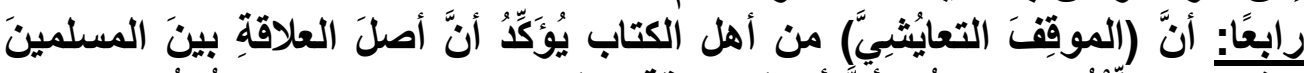

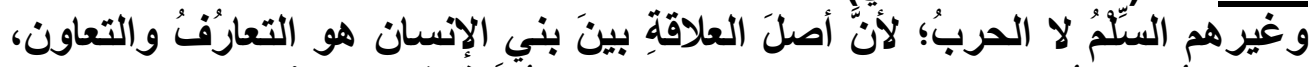

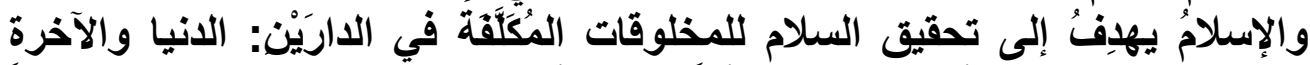

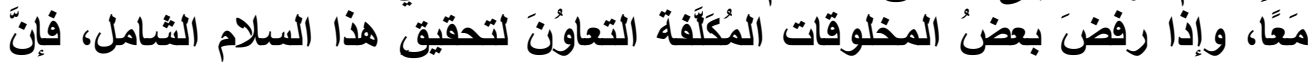

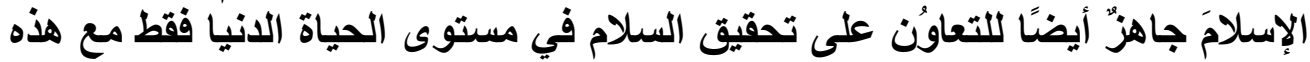

الفئة.

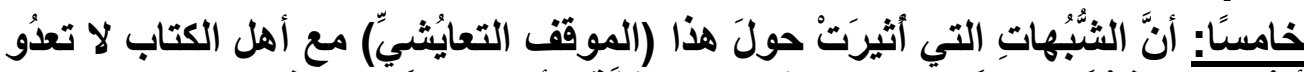

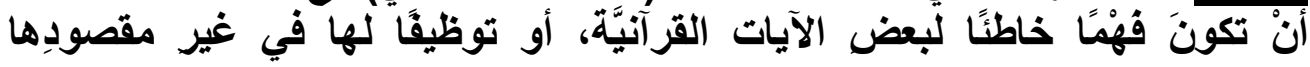
وسياقِها.

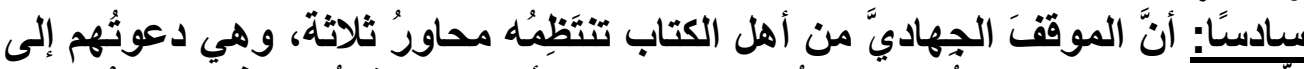

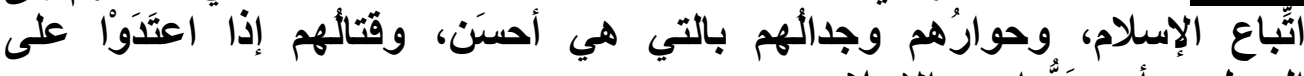

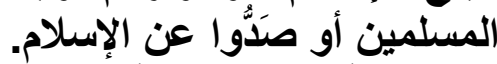

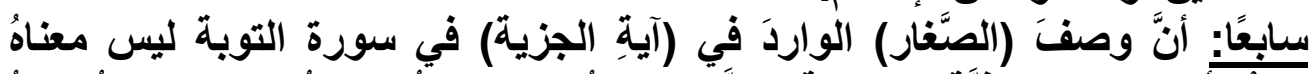

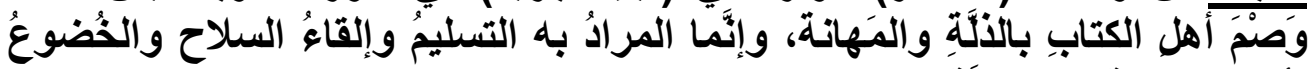
لأحكام الاولة الإسلاميَّة. والحمدُ لله الذي بنعمته تثتُّ الصالحات. 


\section{قائمة المصادر والمراجه}

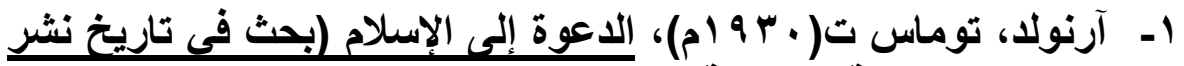

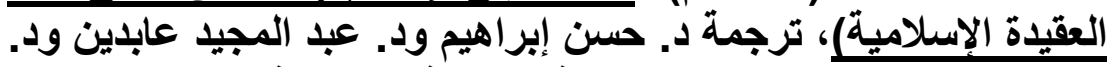

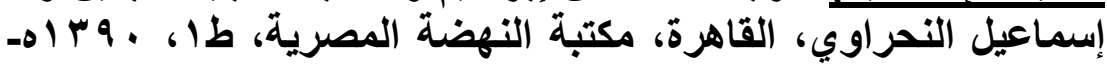

19V1

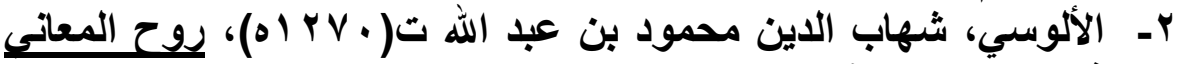

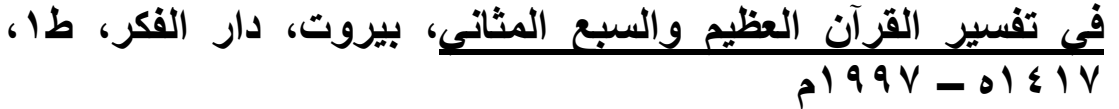

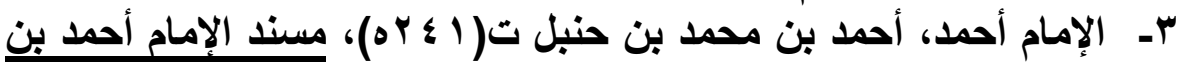

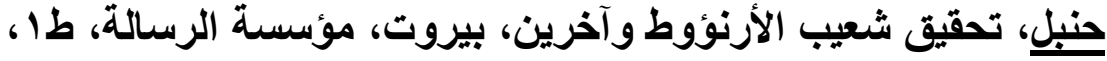

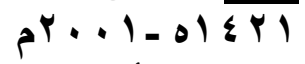

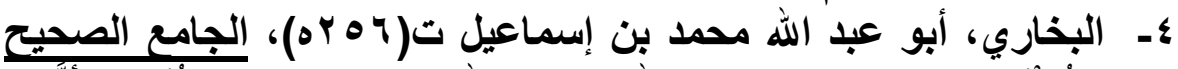

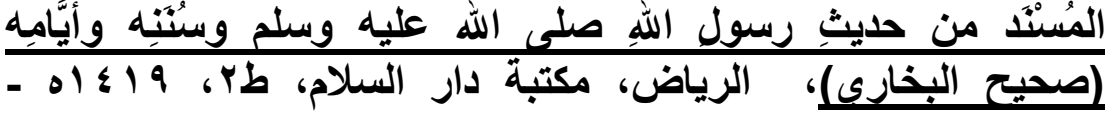

م)

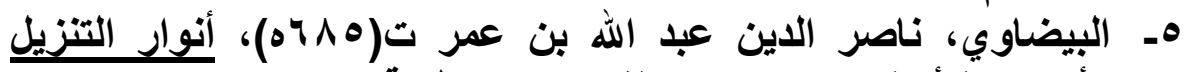

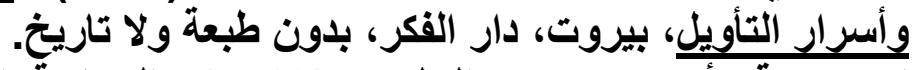

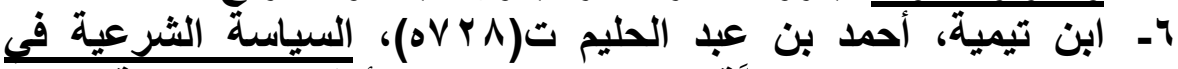

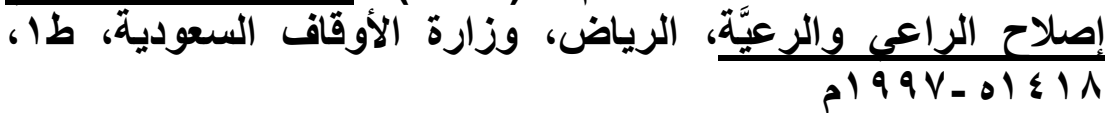

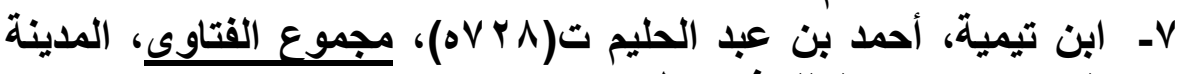

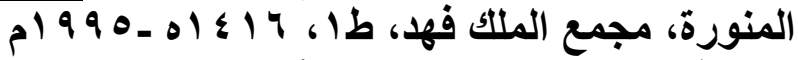

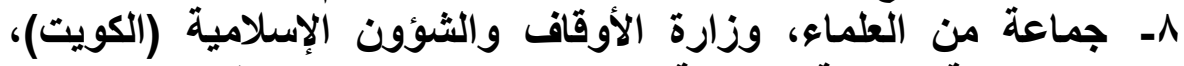

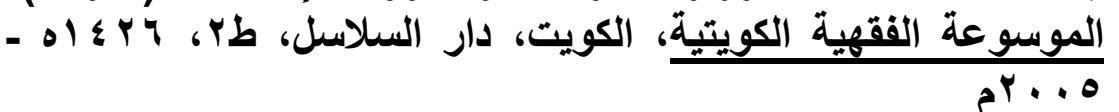

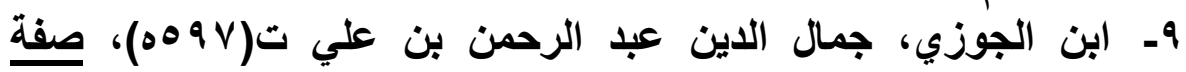

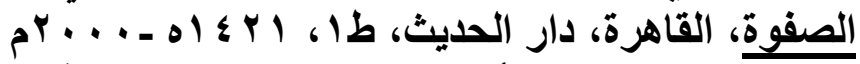

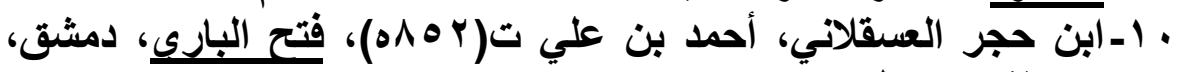

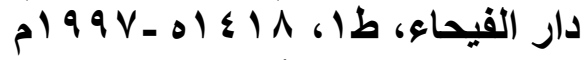

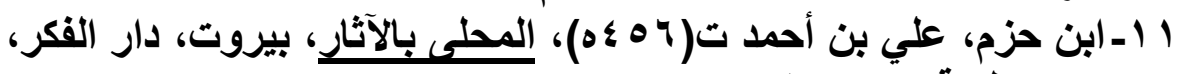
بالون طبعة ولا تاريخ.

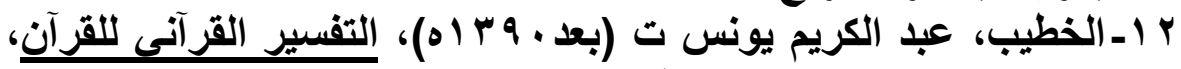

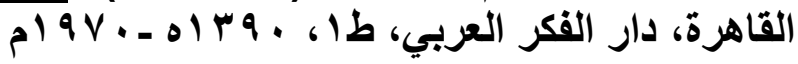




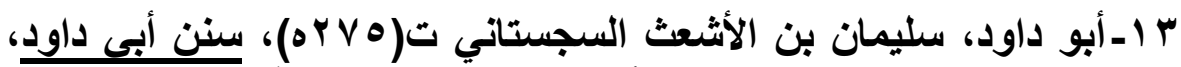

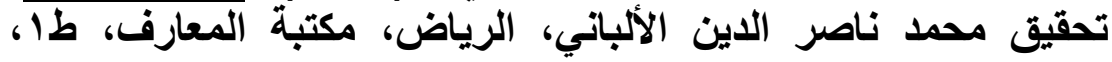
م) $99 V-01 \leqslant 1 V$

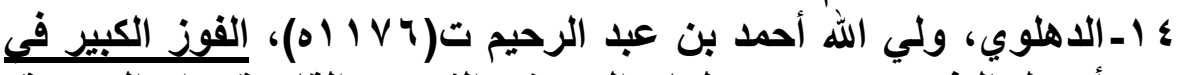

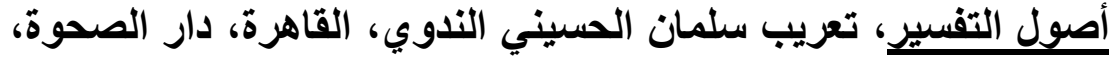

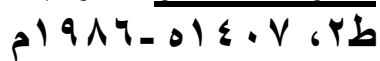

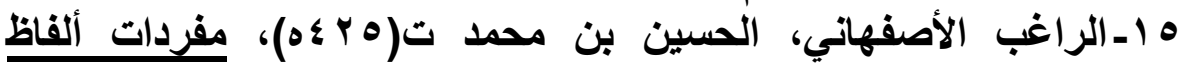

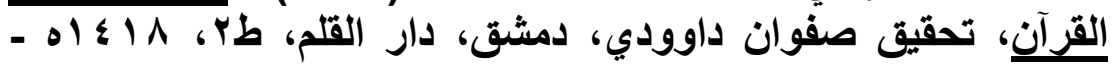
م)

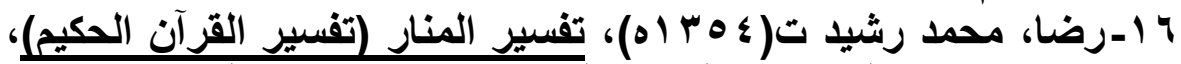

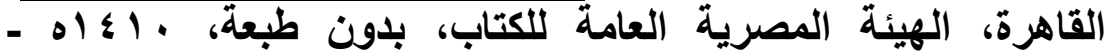
م) 99 .

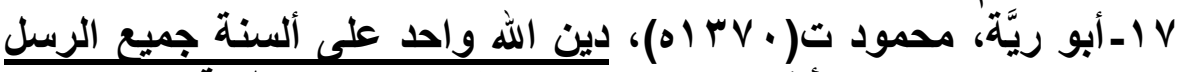

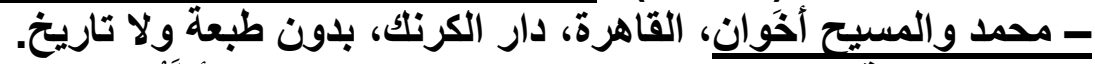

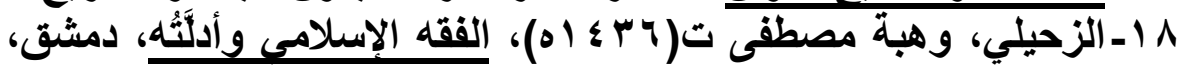

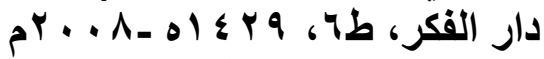

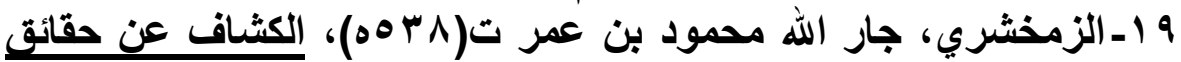

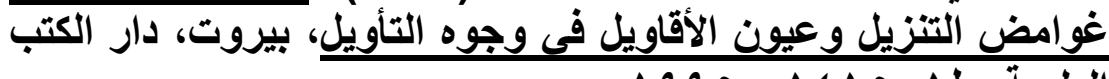

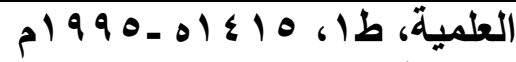

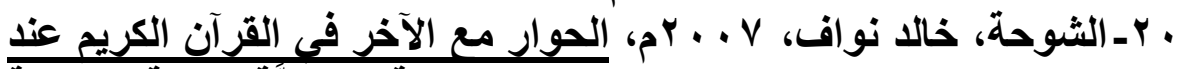

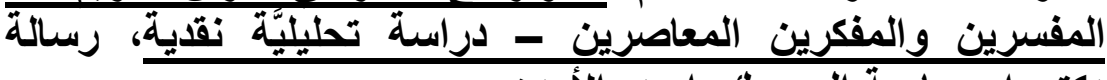

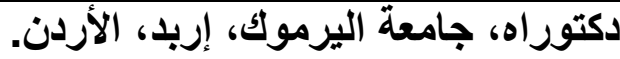

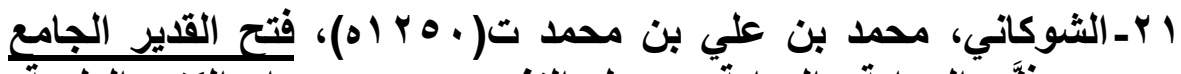

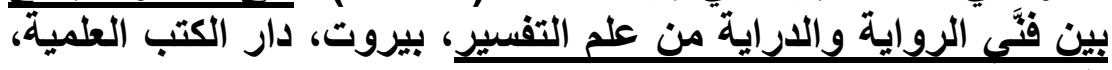
م)

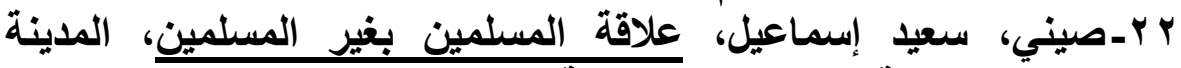

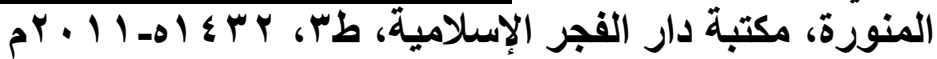

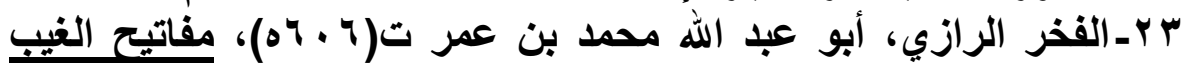

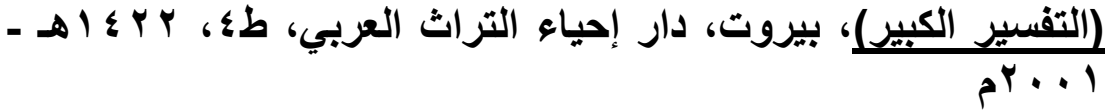

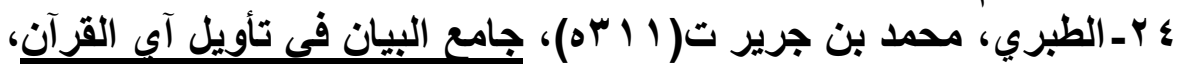

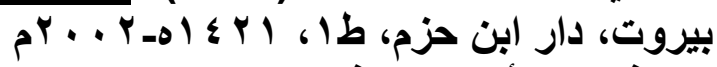

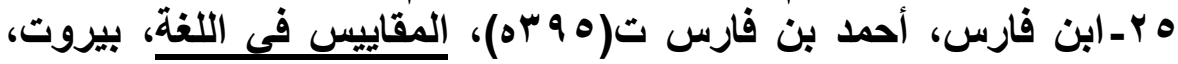

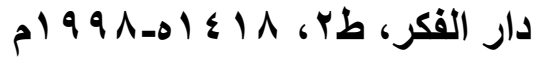




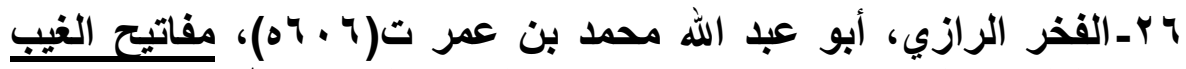

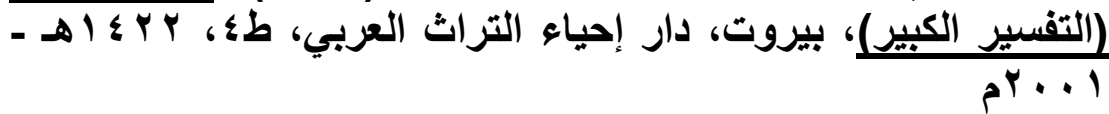

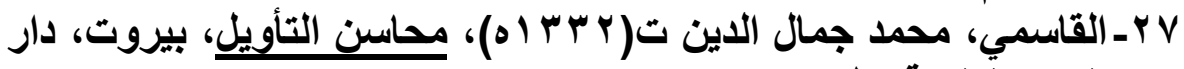

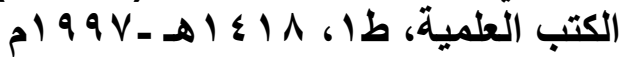

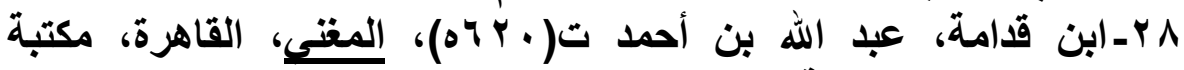

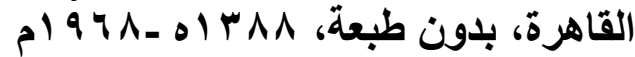

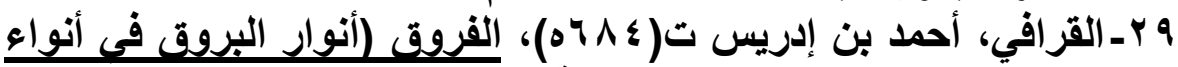

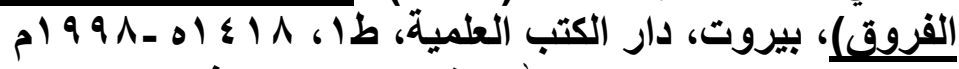

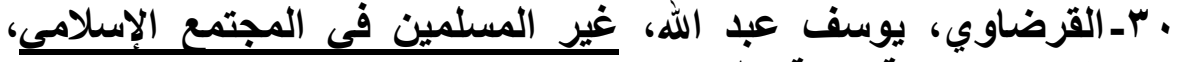

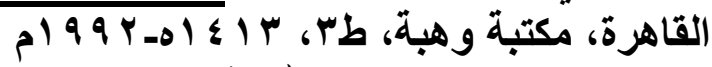

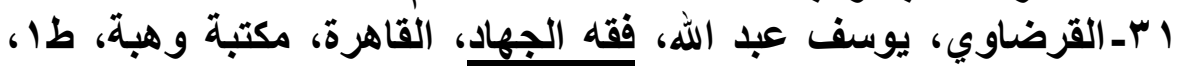
مبا.

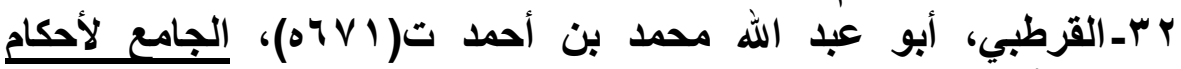

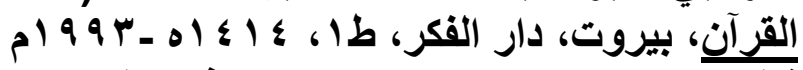

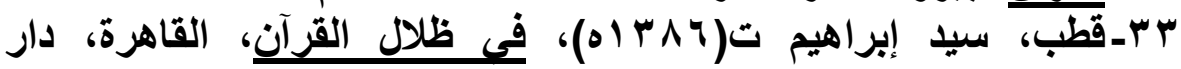

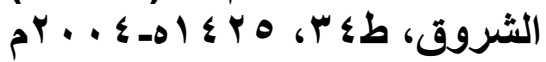

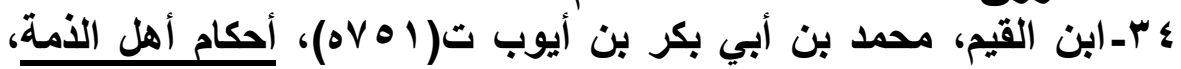

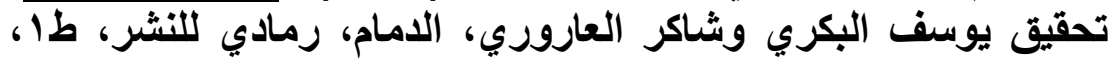

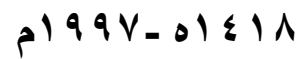

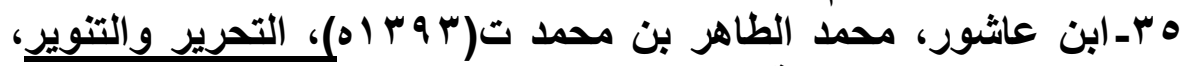

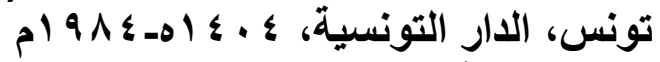

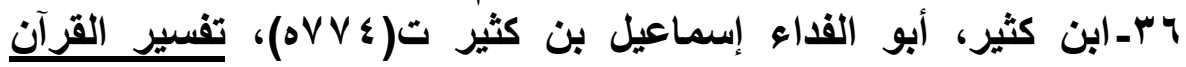

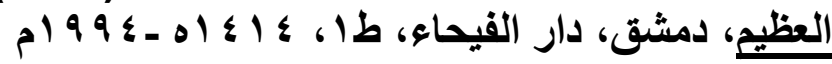

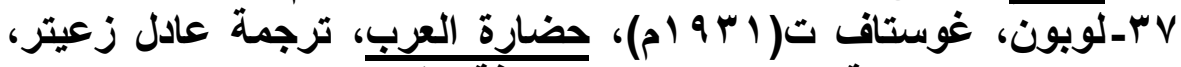

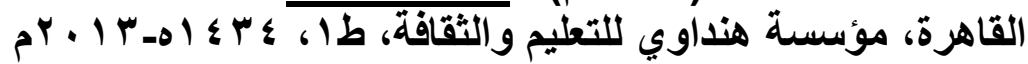

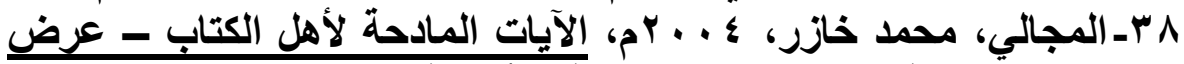

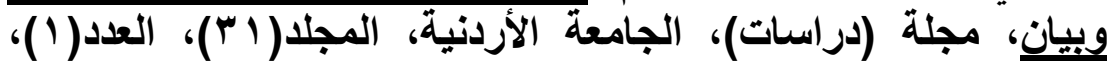

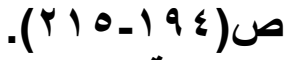

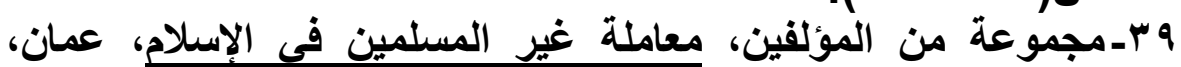

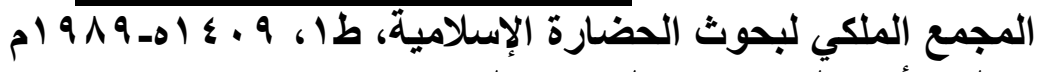

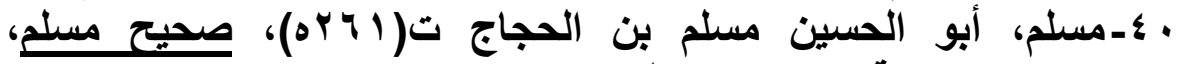

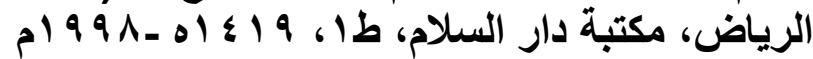

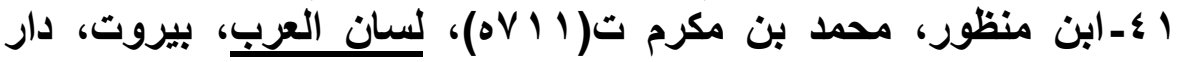

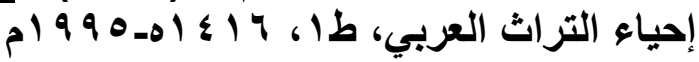




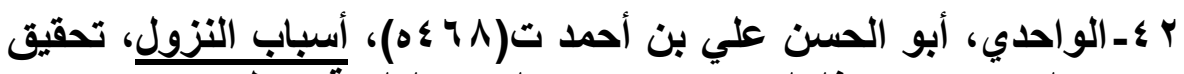

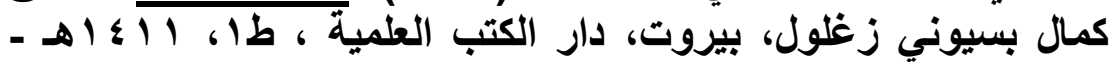

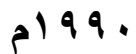

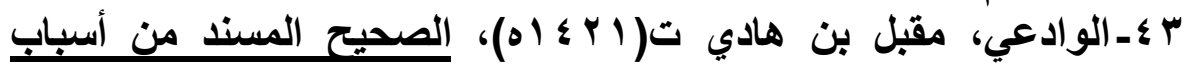

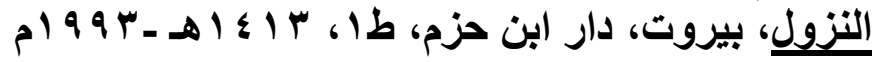

